\title{
Lime induced changes in the surface and soil solution chemistry of variable charge soils
}

\author{
Rajesh Chintala \\ West Virginia University
}

Follow this and additional works at: https://researchrepository.wvu.edu/etd

\section{Recommended Citation}

Chintala, Rajesh, "Lime induced changes in the surface and soil solution chemistry of variable charge soils" (2008). Graduate Theses, Dissertations, and Problem Reports. 4361.

https://researchrepository.wvu.edu/etd/4361

This Dissertation is protected by copyright and/or related rights. It has been brought to you by the The Research Repository @ WVU with permission from the rights-holder(s). You are free to use this Dissertation in any way that is permitted by the copyright and related rights legislation that applies to your use. For other uses you must obtain permission from the rights-holder(s) directly, unless additional rights are indicated by a Creative Commons license in the record and/ or on the work itself. This Dissertation has been accepted for inclusion in WVU Graduate Theses, Dissertations, and Problem Reports collection by an authorized administrator of The Research Repository @ WVU.

For more information, please contact researchrepository@mail.wvu.edu. 


\section{LIME INDUCED CHANGES IN THE SURFACE AND SOIL SOLUTION CHEMISTRY OF VARIABLE CHARGE SOILS}

RAJESH CHINTALA, M.S.

Dissertation submitted to the

Davis College of Agriculture, Forestry, and Consumer Sciences at West Virginia University

In partial fulfillment of the requirements for the degree of

Doctor of Philosophy
in
Plant and Soil Science

Louis McDonald, Ph.D., Chair William Bryan, Ph.D.

Jeffrey Skousen, Ph.D.

Jim Thompson, Ph.D.

Jerald J. Fletcher, Ph.D.

Division of Plant and Soil Sciences

Morgantown, West Virginia

2008 


\section{ABSTRACT}

\section{Lime induced changes in the surface and soil solution chemistry of variable charge soils}

\section{Rajesh Chintala}

The study was conducted to improve lime recommendations as well as to design better management practices for acidic grasslands of Appalachian region. These goals were achieved by two experiments. In the first experiment, the accuracy of lime predictions by quick tests were improved by accounting soil order and develop equation based lime correlations for acidic pasture soils of West Virginia. In order to achieve this objective, 26 surface soil samples $(0-7.5 \mathrm{~cm})$ from three most important soil orders for the state (Alfisols, Inceptisols, Ultisols) from each of the Major Land Resource Areas (MLRAs) in West Virginia with large proportions of pasture land were collected in cooperation with state soil scientists. Standard procedures for the determination of lime requirements by the Mehlich Buffer (MB), Adams-Evans Buffer (AEB) and ShoemakerMcLean-Pratt Single Buffer (SMPB) methods were used. Statistically significant improvements in lime recommendations for target $\mathrm{pH} 6.5$ and 5.5 were achieved by accounting for soil order. Mehlich single buffer recommendations were better for Alfisols and Ultisols than for Entisols to achieve pH 6.5. Lime correlations were developed for all three chemical buffers by multiple regression where the independent variables were target $\mathrm{pH}$ and soil-buffer $\mathrm{pH}$. The Adam-Evans buffer predicted lime rates better for target $\mathrm{pH}$ 5.5. Equation-based lime correlations were also developed for all three chemical buffers by multiple regressions where the independent variables are target $\mathrm{pH}$ and soil-buffer $\mathrm{pH}$. The second experiment was conducted to quantify the critical growth factors such as water potential, $\mathrm{pH}$, nitrogen, and phosphorus and their interactions to deduce a comprehensive prescription of site-specific management techniques to forage production in acidified hill land pastures of West Virginia. In order to achieve this objective, a pot experiment was set up with two water potentials, five $\mathrm{pH}$ levels, five $\mathrm{N}$ and $\mathrm{P}$ fertilizer rates were imposed on bluegrass (sole) and bluegrass + white clover mixture. The estimation of overall effects of these four factors showed that levels of water potential, $\mathrm{pH}, \mathrm{N}$ fertilizer doses as well as their interactions significantly affected the bluegrass (sole) production $(\mathrm{p}<0.05)$. In case of bluegrass and white clover mixture cropping system, all four factors (water potential, $\mathrm{pH}, \mathrm{N}$ and $\mathrm{P}$ levels) and their interactions exhibited significant influence on dry matter yield as well as nutrient concentration in shoot tissue. Nutrient concentrations also showed a synergistic relationship among each other as well as with dry matter yield in both bluegrass and bluegrass + white clover mixture. Response yield function was determined using significant factors and their interactions for blue grass (sole) and blue grass and white clover mixture. 


\section{TABLE OF CONTENTS}

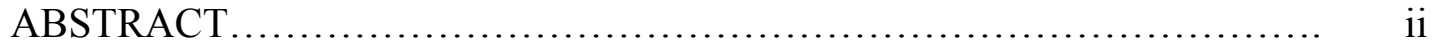

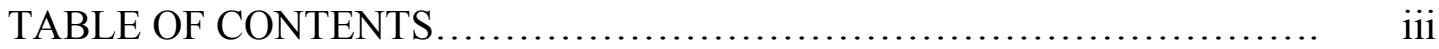

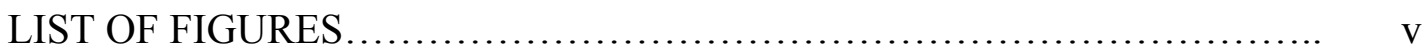

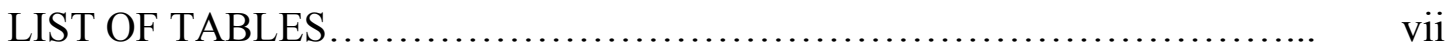

ACKNOWLEDGEMENTS ........................................... ix

Chapter 1. Introduction................................................. 1

1.1. Overview................................................... 1

1.2. Soil Acidity and Liming..................................... 2

1.2.1. Soil Acidification.................................... 2

1.2.2 Lime Requirement..................................... 5

1.2.3 Lime Response....................................... 8

1.3. Nitrogen and Phosphorus..................................... 12

1.3.1. Crop Response to Nitrogen and Phosphorus.............. 12

1.3.2. Nitrogen by Phosphorus Interactions.................... 14

1.3.3. Lime by Nitrogen Interactions........................ 16

1.3.4. Lime by Phosphorus Interactions........................ 17

1.4. Soil water.................................................. 27

1.4.1. Crop Response to Available water...................... 27

1.4.2. Water by Lime by Nitrogen by Phosphorus Interactions.... 29

1.5. Summary..................................................... 36

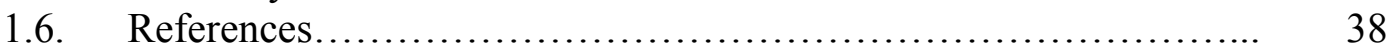

Chapter 2. Grouping Soils by Taxonomic Order to Improve Lime

Recommendations.................................................. 51

2.1. Abstract.................................................. 51

2.2. Introduction............................................... 52

2.3. Objectives.................................................... 54

2.4. Materials and Methods.......................................... 54

2.5. Results and Discussion................................... 56

2.5.1. Determination of lime requirement with chemical buffers.. 56

2.5.2. Effect of soil order on chemical buffer lime requirement $\quad 60$ predictions..........................................

2.5.3. Improved lime recommendation correlations............. 64

2.6. References............................................... 67

Chapter 3. Available Water Effect on Optimum pH, Nitrogen and Phosphorus

Requirements I. Kentucky Bluegrass..................................... 70

3.1. Abstract..................................................... 70

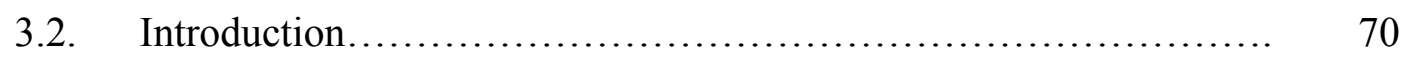

3.3. Materials and Methods........................................ 74

3.4. Results and Discussion....................................... 76

3.4.1. Yield model.......................................... 77

3.4.2. Nutrient Concentration in herbage....................... 84

3.5. References............................................... 91 
Chapter 3. Available Water Effect on Optimum $\mathrm{pH}$, Nitrogen and Phosphorus Requirements II. Kentucky Bluegrass-White clover.......................... 97

4.1. Abstract....................................................... 97

4.2. Introduction.............................................. 98

4.3. Materials and Methods...................................... 99

4.4. Results and Discussion....................................... 102

4.4.1. Yield Model...................................... 102

4.4.2. Nutrient concentration in bluegrass-white clover herbage... $\quad 110$

4.5. References..................................................... 116

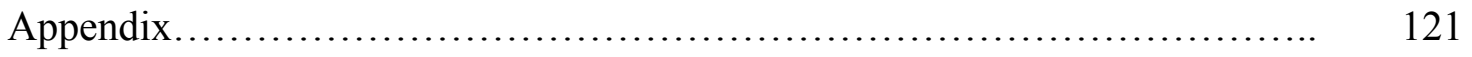




\section{LIST OF FIGURES}

1.2.1. Schematic representation of the terminal edge of an aluminum oxide crystal under three $\mathrm{pH}$ conditions.

1.2.2. Relationship of lime requirements (LR) determined by $\mathrm{Ca}(\mathrm{OH})_{2}$ titration with those determined by incubation. Equation: $\mathrm{Y}=$ $0.889 \mathrm{X}+0.057$

1.2.3. Relationship between soil suspension $\mathrm{pH}$ and percent base saturation.

1.2.4. Changes in $\mathrm{pAl}^{3+}$ with $\mathrm{pH}$ for Clonroche, Mortarstown and Castlecomer soil solutions obtained after 27 and 52 weeks of incubation. Solubility of gibbsite was calculated using a solubility product value of $10^{-34.05}$.

1.3.1. Dependence of dry matter, plant $\mathrm{N}$ uptake, and plant $\mathrm{N}$ concentration on applied nitrogen for coastal Bermudagrass grown at Holland, VA........................................

1.3.2. Effect of $\mathrm{N}$ and $\mathrm{P}$ nutrition on leaf concentration of tomato leaves. 15

1.3.3. Interactive effects of $\mathrm{N}$ and $\mathrm{P}$ nutrition in tomato leaves............ 16

1.3.4. Phosphorus desorption isotherms at three different soil $\mathrm{pH}$ levels with three different initial P addition levels (a) $180 \mu \mathrm{g}$ g-1 of P.

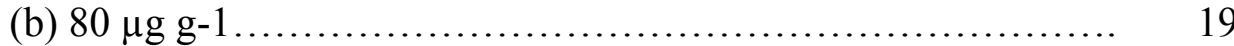

1.3.5. Effect of $\mathrm{P}$ uptake on dry matter yield in white clover.............. 20

1.3.6. Effect of soil $\mathrm{pH}$ and $\mathrm{P}$ rates on solution $\mathrm{P}$ and resin-exchange $\mathrm{P}$ (avg. of four rates of P) for three acid soils.

1.3.7. Soil $\mathrm{P}$ desorption in an extraction sequence with $0.2 \mathrm{M} \mathrm{NaCl}$ at four lime levels............................................. 25

1.3.8. Effect of soil $\mathrm{pH}$ on the $\mathrm{P}$ concentration in soil solution............. 26

1.4.1. Average forage Sorghum dry matter yield for four sampling occasions under the three water regions (A (7 days), B (10 days),

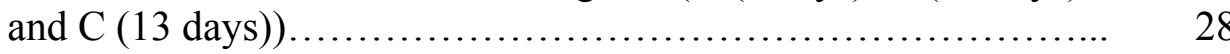

1.4.2. Dry matter yield vs. water use for two cuttings of kenaf grown under an irrigation gradient at Akron, CO in 1997 and 1998.

1.4.3. Predicted marketable watermelon yield, Contour line units are $\mathrm{Mg}$

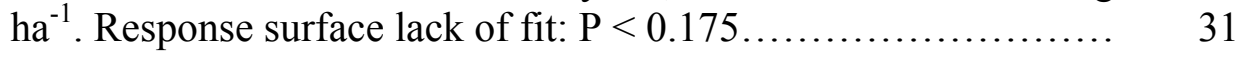

1.4.4. Recovery of applied N on Kachemak silt loam................... 32

1.4.5. Effect of lime application on P-uptake by perennial rye grass....... 34

1.4.6. Net charge per mole of added $\mathrm{P}$ at different $\mathrm{pH}$ values in four different soils.

2.5.1. Lime requirement of 25 pasture soils as measured by three buffer methods vs. $\mathrm{Ca}(\mathrm{OH})_{2}$ titration................................ 60

2.5.2a. Lime requirement of Alfisols as measured by three buffer methods vs. $\mathrm{Ca}(\mathrm{OH})_{2}$ titration

2.5.2b. Lime requirement of Inceptisols as measured by three buffer methods vs. $\mathrm{Ca}(\mathrm{OH})_{2}$ titration............................... 63

2.5.2c. Lime requirement of Ultisols as measured by three buffer methods vs. $\mathrm{Ca}(\mathrm{OH})_{2}$ titration 
3.4.1. Residuals plot for herbage accumulation....................... 77

3.4.2. Actual vs. predicted herbage accumulation...................... $\quad 78$

3.4.3. Effect of water potential and $\mathrm{pH}$ level on Kentucky bluegrass herbage accumulation......................................... $\quad 80$

3.4.4. Effect of water potential and $\mathrm{N}$ level on Kentucky bluegrass herbage accumulation.......................................... 82

3.4.5. Effect of $\mathrm{pH}$ and $\mathrm{N}$ levels on Kentucky bluegrass herbage accumulation................................................... 83

3.4.6. Effect of water potential and $\mathrm{N}$ levels on $\mathrm{N}$ concentration in tissue $\quad 86$

3.4.7. Effect of water potential and $\mathrm{pH}$ on $\mathrm{K}$ concentration in tissue...... 88

3.4.8. Effect of water potential and $\mathrm{pH}$ on $\mathrm{Ca}$ concentration in tissue.... $\quad 89$

3.4.9. Effect of water potential and $\mathrm{pH}$ on $\mathrm{Mg}$ concentration in tissue.... $\quad 90$

4.4.1. Actual vs. predicted herbage accumulation using the model......... 103

4.4.2. Residual vs. predicted values of herbage accumulation using the model..................................................... 103

4.4.3. Effect of water potential and $\mathrm{N}$ level on herbage accumulation of bluegrass and white clover mixture............................ 106

4.4.4. Effect of water potential and $\mathrm{pH}$ level on herbage accumulation of bluegrass and white clover mixture............................. 107

4.4.5. Effect of $\mathrm{N}$ and $\mathrm{P}$ level on herbage accumulation of bluegrass and white clover mixture....................................... 108

4.4.6. Effect of nitrogen and $\mathrm{pH}$ level on herbage accumulation of bluegrass and white clover mixture............................. 109

4.4.7. Effect of $\mathrm{pH}$ and $\mathrm{N}$ level on $\mathrm{N}$ concentration of tissue.............. 112

4.4.8. Effect of water potential and $\mathrm{P}$ level on $\mathrm{P}$ concentration of tissue... 113

4.4.9. Effect of $\mathrm{pH}$ and $\mathrm{P}$ level on $\mathrm{P}$ concentration of tissue............... 114

4.4.10. Effect of water potential and $\mathrm{pH}$ level on $\mathrm{Mg}$ concentration of tissue........................................................... 115

A1. Lime response curve of green house soil....................... 126

A2. Moisture pattern in high water potential treatment plants........... 127

A3. Moisture pattern in low water potential treatment plants............ 128 


\section{LIST OF TABLES}

1.2.1. Nitrogen reactions in soils and their net effect on $\mathrm{H}^{+}$production........ 3

1.3.1. Influence of $\mathrm{P}$ and thiourea $(\mathrm{TH})$ on seed yield and shoot dry matter (DM) of cluster bean under water stress (D) ...................... 14

1.3.2. Effect of lime and superphosphate applications on pasture growth and

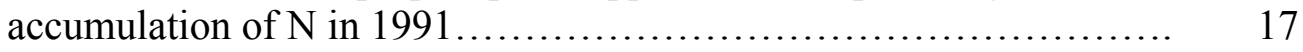

1.3.3. Effect of lime and $\mathrm{P}$ treatments on $\mathrm{P}, \mathrm{Al}, \mathrm{Mn}, \mathrm{Ca}, \mathrm{Mg}, \mathrm{K}$ and $\mathrm{Na}$ concentrations in saturation paste extracts......................... 21

1.3.4. Effect of lime and $P$ treatments on the amount of available P extracted by various methods.

1.3.5. Effects of lime and $\mathrm{P}$ treatments on the various inorganic soil $\mathrm{P}$ fractions.........................................................

1.3.6. Simple correlation coefficients (r) between extractable soil P and total yield and $\mathrm{P}$ uptake of lotus and white clover.

1.4.1. Effect of moisture content on N-mineralization in forest soils.......... 30

1.4.2. Influence of soil moisture content on P uptake by corn............... 32

1.4.3. Liming effect on $\mathrm{N}$-mineralization in soils from six year pot experiment.

1.4.4. Influence of $\mathrm{P}$ application on Water use efficiency (WUE) of plants under stressed conditions.

2.5.1. Mean, range and standard deviation of soil $\mathrm{pH}$, silt, clay and organic matter contents and cation exchange capacity (CEC) grouped by soil order

2.5.2. Mean LR values for different target $\mathrm{pH}$ levels.........................

2.5.3. Comparison of buffer methods with direct calcium hydroxide titration method for different target $\mathrm{pH}$ levels before grouping by soil order....

2.5.4. Soil grouping effect on lime requirement by quick tests for different target $\mathrm{pH}$ levels

2.5.5. Regression equations to predict lime requirements for target $\mathrm{pH} 5.5 \ldots \quad 65$

2.5.6. Regression equations to predict lime requirements for target $\mathrm{pH} 6.0 \ldots \quad 65$

2.5.7. Regression equations to predict lime requirements for target $\mathrm{pH} 6.5 \ldots \quad 66$

3.4.1. Analysis of variance for model of response surface function........... $\quad 77$

3.4.2. Analysis of variance for the overall and interaction effects of the four factors on bluegrass yield..................................... $\quad 79$

3.4.3. Predicted herbage accumulation at optimum conditions............... 84

3.4.4. Model significance of nutrient concentration in Kentucky bluegrass... 85

4.4.1. Analysis of variance for the response model......................... 102

4.4.2. ANOVA for effect of factors and their interactions on herbage accumulation of bluegrass and white clover mixture................. 105

4.4.3. Predicted response for different levels of four factors.................. 110

4.4.4. Model significance for effects of factors and their interactions on nutrient concentrations in Kentucky bluegrass-white clover mixture... 
A1 Mean lime requirement $\left(\mathrm{Mg} \mathrm{ha}^{-1}\right)$ values by direct calcium hydroxide titration method..............................................

A2 Mean lime requirement $\left(\mathrm{Mg} \mathrm{ha}^{-1}\right)$ values by Shoemaker McLean Pratt buffer (SMP) method..............................................

A3 Mean lime requirement $\left(\mathrm{Mg} \mathrm{ha}^{-1}\right)$ values by Adam Evans buffer (AEB) method...

A4 Mean lime requirement $\left(\mathrm{Mg} \mathrm{ha}^{-1}\right)$ values by Mehlich single buffer (MB) method

A5 Experimental design used for bluegrass (alone) and bluegrass and white clover mixed cropping system............................... 


\section{ACKNOWLEDGEMENTS}

I would like to take this opportunity to express my sincere appreciation and gratitude to my advisor, Dr. Louis McDonald, for his meticulous guidance, benign attitude, and constant support through out this project. I take it as a great privilege and pride to have had an opportunity of working under his guidance. I would also thank each one of my committee members, Dr. William Bryan, Dr. Jeffrey Skousen, and Dr. Jim Thompson for their valuable suggestions.

I extend my thanks to Joan Wright for her lab support through out my program. I also deeply acknowledge the help of Ken Stewart during the analysis of cations and anions using IC (NRCCE) and greenhouse staff (Gale and Sue Myers) for allowing me to conduct pot experiments. I express my heartfelt thanks to my friends Charles and Satya for their help and support to my research. I also extend thanks to my colleagues, Sri, Mimi, Jared, and Rishi.

It is my privilege to thank my parents, Venugopal (Father) and Kamlamma (Mother), and Satish (Brother) for their uninterrupted support and encouragement throughout my life as well as during my research.

Most importantly, I would like to express sincere appreciation to my wife, Hema, for her assistance, encouragement, and understanding during the course of this study. 


\section{CHAPTER I}

\section{INTRODUCTION}

\subsection{Overview}

In West Virginia, the total area of farm land is 1.40 million hectares $(22.4 \%$ of the total land area) of which 0.21 million hectares of land is under pasture (National Agricultural Statistics Service, 2005) spread on undulating terrain. The soils on this rugged terrain range from Entisols and Inceptisols on recent deposits to Alfisols, Ultisols, Mollisols, and Spodosols on older, more stable surfaces. The hills and uplands of the Appalachian region have limitations on agricultural productivity because of climate, soil and physical features such as slope gradient and slope aspect. A forage-based cropping system allows economic use of land unsuitable for production of arable crops. Grassland is more efficient in reducing erosion because of the fibrous mass of roots that bind soil particles better than row crops. The growth of grasses promotes granulation of soil particles and crumb formation. The absorptive capacity of the soil for water and infiltration rate is also improved along with reduction in impact of rain drops. Finally the herbage on the surface offers mechanical obstruction to water moving over the soil and the velocity of runoff is greatly reduced. Together these make grass-based farming systems ideal for reducing runoff and erosion and improving sustainability of production on the soils of West Virginia.

State rainfall averages nearly $102 \mathrm{~cm}$ per anum that results in a removal rate of base cations that exceeds the rate of their liberation from non-exchangeable forms 
(DeWalle et al., 1985). As a result of factors such as high precipitation and undulating topography, the pasture soils of West Virginia, though of mixed mineralogy, have a large variable charge mineral content (Ritchey and Snuffer, 2002). Rainfall is not uniformly distributed spatially or temporally across the state. This and the undulating topography create conditions where water potential can vary within a particular field or farm.

The goal of this research is to provide guidance for the way pasture soils are divided into management zones in the Appalachian region generally, and West Virginia in particular. The primary yield-liming factors were assumed to be available water (related to landscape position), and acidic soils. This was accomplished with two separate, but intimately related experiments. The first was designed to determine the best way to make lime recommendations for all soils in the state. The second was to determine the optimal $\mathrm{pH}, \mathrm{N}$ and $\mathrm{P}$ needs as a function of water potential for bluegrass (alone) and a bluegrass and white clover mixture.

\subsection{Soil Acidity and Liming}

\subsubsection{Soil Acidification}

Soil acidification is a natural process which can be accelerated by the activity of humans and ameliorated with proper management. Soil acidity causes harmful effects to both plants and soil organisms (Runge and Rode, 1991). Acid soil infertility has been attributed to manganese and aluminum toxicity (Adams, 1984). The two most important acid generating processes in any natural ecosystem resulting from human activities are acid drainage from pyrite oxidation and acid deposition (Longhurst, 1991; Evangelou, 
1995). In managed ecosystems, plant-induced processes such as carbon assimilation, uptake and assimilation of nitrogen and sulfur, and soil-mediated processes such as decomposition of organic matter, transformation of nitrogen (Table 1.2.1) and sulfur are important acid generating processes (Bolan et al., 2003). However, in West Virginia, the primary cause for the acidification of pasture soils is excess of rainfall over evopotranspiration, the resulting leaching of base cations and the formation of acidic variable charge minerals in surface soils (Ritchey and Snuffer, 2002).

Table 1.2.1. Nitrogen reactions in soils and their net effect on $\mathrm{H}^{+}$production. (Bolan et al., 2003).

\begin{tabular}{llc}
\hline Process & Reaction & $\mathrm{H}^{+}$ \\
\hline & & $\left(\mathrm{mol}_{\mathrm{c}} \cdot \mathrm{mol}^{-1}\right)$ \\
$\mathrm{N}$ fixation & $2 \mathrm{~N}_{2}+2 \mathrm{H}_{2} \mathrm{O}+4 \mathrm{ROH} \rightarrow 4 \mathrm{RNH}_{2}+3 \mathrm{O}_{2}$ & 0 \\
Mineralization of organic $\mathrm{N}$ & $\mathrm{RNH}_{2}+\mathrm{H}^{+}+\mathrm{H}_{2} \mathrm{O} \rightarrow \mathrm{ROH}+\mathrm{NH}_{4}^{+}$ & -1 \\
Urea hydrolysis & $\left(\mathrm{NH}_{2}\right)_{2} \mathrm{CO}+3 \mathrm{H}_{2} \mathrm{O} \rightarrow 2 \mathrm{NH}_{4}^{+}+2 \mathrm{OH}^{-}+\mathrm{CO}_{2}$ & -1 \\
Ammonium assimilation & $\mathrm{NH}_{4}^{+}+\mathrm{ROH} \rightarrow \mathrm{RNH}_{2}+\mathrm{H}_{2} \mathrm{O}+\mathrm{H}^{+}$ & +1 \\
Ammonia volatilization & $\mathrm{NH}_{4}^{+}+\mathrm{OH}^{-} \rightarrow \mathrm{NH}_{3}+\mathrm{H}_{2} \mathrm{O}$ & +1 \\
Nitrification & $\mathrm{NH}_{4}^{+}+2 \mathrm{O}_{2} \rightarrow \mathrm{NO}_{3}^{-}+\mathrm{H}_{2} \mathrm{O}+2 \mathrm{H}^{+}$ & +2 \\
Nitrate assimilation & $\mathrm{NO}_{3}^{-}+8 \mathrm{H}^{+}+8 \mathrm{e}^{-} \rightarrow \mathrm{NH}_{3}+2 \mathrm{H}_{2} \mathrm{O}+\mathrm{OH}^{-}$ & -1 \\
Denitrification & $4 \mathrm{NO}_{3}^{-}+4 \mathrm{H}^{+} \rightarrow 2 \mathrm{~N}_{2}+5 \mathrm{O}_{2}+2 \mathrm{H}_{2} \mathrm{O}$ & -1 \\
\hline
\end{tabular}

Minerals with $\mathrm{pH}-\mathrm{dependant} \mathrm{surface}$ charge (amphoteric minerals) include kaolinite, oxides and hydroxides of $\mathrm{Fe}$ and $\mathrm{Al}$ and their complexes with organic matter (Dahlgren et al., 1993; Parfitt, 1980; Zhang and Zhao, 1997). Variable charge arises from the protonation and deprotonation of functional groups at mineral surfaces and organic matter. In acid conditions, an excess of adsorbed $\mathrm{H}^{+}$results in a net positive charge at the oxygen and hydroxyl functional groups (Fig. 1.2.1a). At high $\mathrm{pH}$ condition oxygen deprotonation is induced along with the surface gaining a net negative charge (Fig. 1.2.1c). At some intermediate $\mathrm{pH}$, the positive and negative charges are equal (Fig. 
1.2.1b). This $\mathrm{pH}$ is referred to as the point of zero charge (PZC). Generally, the PZC represents the $\mathrm{pH}$ of maximum particle agglomeration and lowest potential mineral solubility (Parks and DeBruyn, 1962). As a result of variable charge dominant mineralogy and acidic $\mathrm{pH}$, soils in West Virginia and the Appalachian region tend to have a low cation exchange capacity (3-21 $\left.\mathrm{cmol}_{\mathrm{c}} \mathrm{kg}^{-1}\right)$ (NRCS, 2004).

a

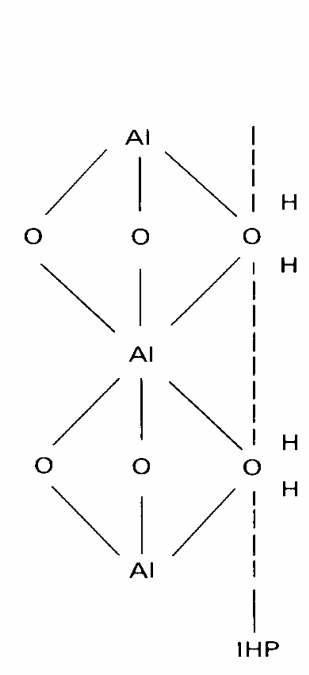

Surface charge +2 b

Increasing $\mathrm{pH}$

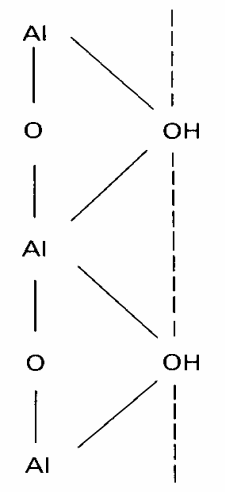

o

$\mathrm{pH}=7.0$ c

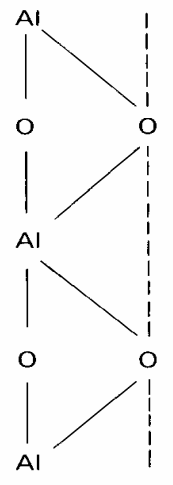

$-2$

$\mathrm{pH}=9.0$

Fig. 1.2.1. Schematic representation of the terminal edge of an aluminium oxide crystal under three $\mathrm{pH}$ conditions. (Brady and Weil, 1990).

The metal most commonly associated with soil acidification is $\mathrm{Al}^{3+}$ which occupies a greater proportion of cation exchange sites and reduces base saturation (Jenny and Overstreet, 1939). Soil acidification changes the equilibrium, partitioning and speciation of metals in the soil solution. In general, the solubility and mobility of most metals increases with decreasing $\mathrm{pH}$. Aluminum ions on mineral surfaces hydrolyze to 
produce $\mathrm{H}^{+}$, which in turn attacks the clay surfaces to produce more acidity (Eq. [1.2.1]), (Bolan et al., 2003),

$$
\mathrm{Al}^{3+}+\mathrm{nH}_{2} \mathrm{O} \leftrightarrow \mathrm{Al}(\mathrm{OH})_{3}^{\mathrm{n}-3}+\mathrm{nH}^{+}
$$

In addition to the direct toxicity of $\mathrm{Al}^{3+}$, especially to growing root tips, soil aluminum reduces the available pool of alkali and alkali earth elements (base cations) (Ulrich, 1994). Al toxicity can also have a substantial inhibitory effect on the uptake and translocation of $\mathrm{P}$ (Chen and Barber, 1990). Soil acidification also decreases the number of plant species in natural grassland (Goulding and Annis, 1998; Tilman et al., 1994).

\subsubsection{Lime Requirement}

The oldest definition of a lime requirement (McBride, 1994) was the amount of $\mathrm{CaCO}_{3}$ (or its equivalent in any other alkaline material needed to neutralize all exchangeable acidity and bring the soil to 100 percent base saturation. More modern definitions of lime requirement are variations of McLean (1973) "the amount of liming material which must be applied to a soil to raise its $\mathrm{pH}$ from an initial acid condition to a level selected for near optimum plant growth". The soil physico-chemical factors that have been shown to influence LR include CEC, clay type and content, organic matter content, buffer capacity, total and exchangeable acidity (Machacha, 2004). Lime requirement values are correlated negatively with soil $\mathrm{pH}$ and positively with total acidity and exchangeable $\mathrm{Al}$ (Halder and Mandal, 1985). The most direct method to determine lime requirement is by direct incubation with $\mathrm{CaCO}_{3}$. However, this approach is not 
practical for routine soil test laboratory recommendations. Therefore, various chemical methods (quick tests) have been developed to determine lime requirements for acid soils (McLean and Brown 1984). These include:

(a). Titration of the soil with $\mathrm{Ca}(\mathrm{OH})_{2}$ which allows soil $\mathrm{pH}$ to be raised to any chosen value (Abruna et al.,1955)

(b). Single chemical buffer methods of Woodruff (1948), Shoemaker, McLean, and Pratt (SMP) (1961), Adams and Evans buffer method (AEB) (1962), and Mehlich single buffer method (MB) (1976). Single buffer methods are based on the principle that the $\mathrm{pH}$ of a buffer solution when mixed with soil will decrease linearly in response to the exchangeable hydrogen $\left(\mathrm{H}^{+}\right)$content of the soil solution (Alabi et al., 1986)

(c). Improved double buffer methods of McLean et al., (1978) and Yuan (1974), which possess greater sensitivity and takes into account the buffering capacity of the soil

(d). Exchangeable Al extracted with an unbuffered salt such as potassium chloride (Kamprath, 1970).

The choice of a quick test (buffer method) and its lime requirement depends on the soil properties such as amount of exchangeable aluminum, cation exchange capacity, and amorphous Al content of the soil (Bolan et al., 2003). The lime requirements of acidic soils were highly correlated with exchangeable Al and total acidity (Patiram and Prasad, 1991). However, soil components such as organic carbon and clay minerals were more important in controlling the magnitude of lime requirement of acid soils with the same degree of weathering (Chen and Lin, 1994). 
Comparative studies of different methods for estimating lime requirement have been carried out all over the world to determine the suitability of the selected method. Webber et al. (1977) observed that the Woodruff and SMP methods gave lime requirement values that were highly correlated with values from the incubation method for 39 soils from Canada, whereas Curtin et al. (1984) found that the SMP method underestimated the lime requirement for Saskachevan soils. The SMP method was recommended as the diagnostic tool to predict the lime requirement of acid Ghanaian soils due to its simplicity and shorter analytical time (Owusu-Bennoah et al., 1995). However, Brown and Cisco (1984) found that the SMP buffer method underestimated the lime requirement for low buffer capacity soils and overestimated it for high lime requirement soils. Therefore, the double buffer SMP method was introduced to improve the sensitivity for low buffer capacity soils. The SMP double buffer method gave the best results for both high and low lime requirement soils and was particularly impressive at the lower pH targets of low buffered soils (Shoemaker et al., 1961). Daniel et al. (1989) found that the double buffer method of McLean (1978) was more accurate for soils with a low lime requirement, and the SMP single buffer method was more accurate for soils with a high lime requirement. The Mehlich single-buffer method worked well in two different soil $\mathrm{pH}$ conditions and demonstrated good correlations with lime requirements to $\mathrm{pH} 5.5\left(\mathrm{R}^{2}=0.78\right)$ and $\mathrm{pH} 6.69\left(\mathrm{R}^{2}=0.80\right)$. Compared with the double-buffer methods (which need two $\mathrm{pH}$ measurements), the single-buffer methods were better correlated with lime requirements and easier for laboratories that handle numerous samples (Aitken et al., 1990). 
Lime incubation with calcium carbonate is an accurate reference method for comparative studies of chemical buffers to predict lime requirements for soil. However, lime incubations are also time and labor intensive tests. Fortunately direct titration with $\mathrm{Ca}(\mathrm{OH})_{2}$ has been shown to be an accurate substitute (Alabi et al., 1986) (Fig. 1.2.2).

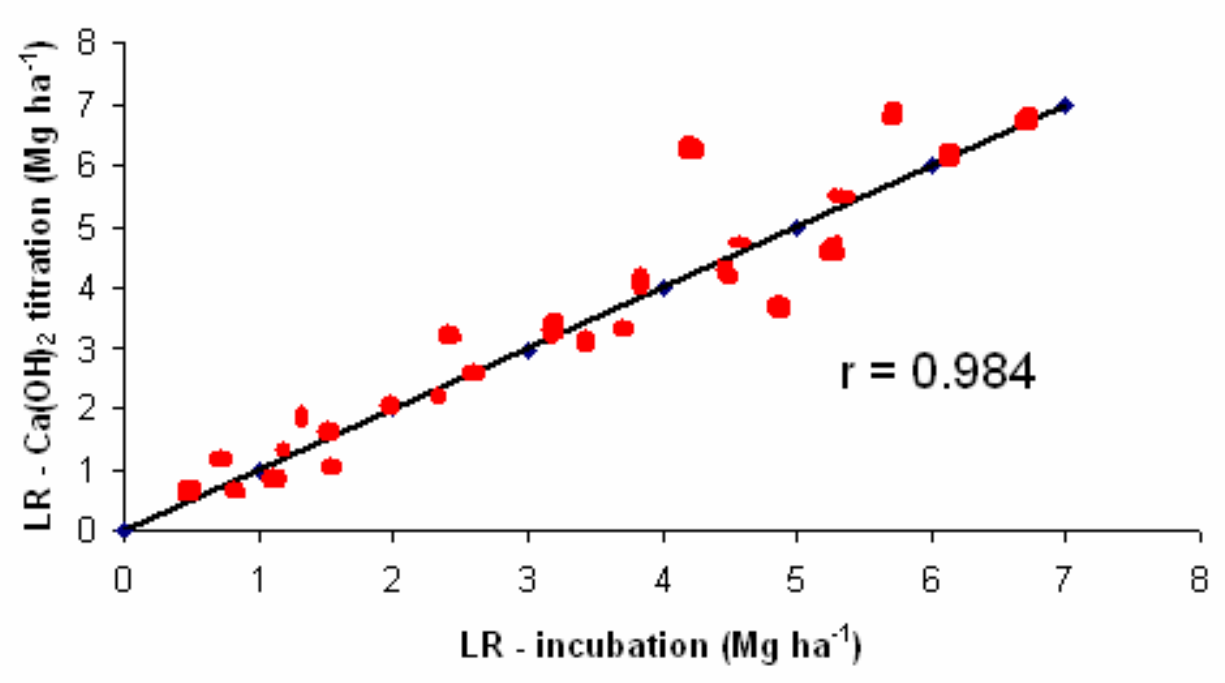

Fig. 1.2.2. Relationship of lime requirements (LR) determined by $\mathrm{Ca}(\mathrm{OH})_{2}$ titration with those determined by incubation. Equation: $\mathrm{Y}=0.889 \mathrm{X}+0.057$ (Alabi et al., 1986).

\subsubsection{Lime Response}

Liming is the most common practice used to overcome the impact of soil acidification in agricultural soils. However, an integrated approach involving liming, cultural practices and plant tolerance will probably be necessary, particularly where the acidification potential is high and its effect is likely to extend into the subsoil (Bolan et al., 2003). A range of liming materials is available, which vary in their ability to 
neutralize acidity. These include calcite $\left(\mathrm{CaCO}_{3}\right)$, burnt lime $(\mathrm{CaO})$, slaked lime $\left(\mathrm{Ca}(\mathrm{OH})_{2}\right)$, dolomite $\left(\mathrm{Ca} \mathrm{Mg}\left(\mathrm{CO}_{3}\right)_{2}\right)$ and slag $\left(\mathrm{CaSiO}_{3}\right)$. The acid neutralizing value of liming materials is expressed in terms of its calcium carbonate equivalent (CCE), defined as the acid neutralizing capacity of liming materials expressed as a weight percentage of pure $\mathrm{CaCO}_{3}$. The amount of liming material required to rectify soil acidity depends on the neutralizing value of the liming material and the $\mathrm{pH}$ buffering capacity of the soil. Lime neutralizes acidity by reacting with free $\mathrm{H}^{+}$(Eq. [1.2.2]),

$$
2 \mathrm{H}^{+}+\mathrm{CaCO}_{3} \rightarrow \mathrm{Ca}^{2+}+\mathrm{H}_{2} \mathrm{O}+\mathrm{CO}_{2}
$$

Free $\mathrm{H}^{+}$results from aluminum hydrolysis (Eq. [1.2.1]), dissociation from organic matter functional groups (Eq. [1.2.3]),

$$
\mathrm{R}-\mathrm{COOH} \leftrightarrow \mathrm{R}-\mathrm{COO}^{-}+\mathrm{H}^{+}
$$

or from any other reaction that produces a proton. The complete neutralization reaction can be written as

$$
\mathrm{ExAl}+\frac{3}{2} \mathrm{CaCO}_{3}+\frac{1}{2} \mathrm{H}_{2} \mathrm{O} \stackrel{\mathrm{H}_{2} \mathrm{O}}{\longrightarrow} \mathrm{Al}(\mathrm{OH})_{3}+\frac{3}{2} \mathrm{ExCa}+\frac{3}{2} \mathrm{CO}_{2}
$$

The net result of all these reactions is to increase the soil $\mathrm{pH}$ and base saturation (Fig. 1.2.3) and displace the $\mathrm{Al}^{3+}$ from the exchangeable complex and precipitate it as 
unavailable hydroxides. Curtin and Smillie (1983) limed three acid soils with $\mathrm{CaCO}_{3}$ and incubated them for 52 weeks at field capacity and observed that the activity of $\mathrm{Al}^{3+}$ was linearly correlated with solution $\mathrm{pH}$. There was a significant decrease in $\mathrm{Al}$ solubility with time (increase of slope of $\mathrm{pAl}^{3+} / \mathrm{pH}$ ) due to slow crystallization of the $\mathrm{Al}$ precipitate (hydroxides of $\mathrm{Al}$ ) and the proportion of total $\mathrm{Al}$ increased in organic complexes increased with $\mathrm{pH}$ in 27 and 52 weeks (Fig. 1.2.4).

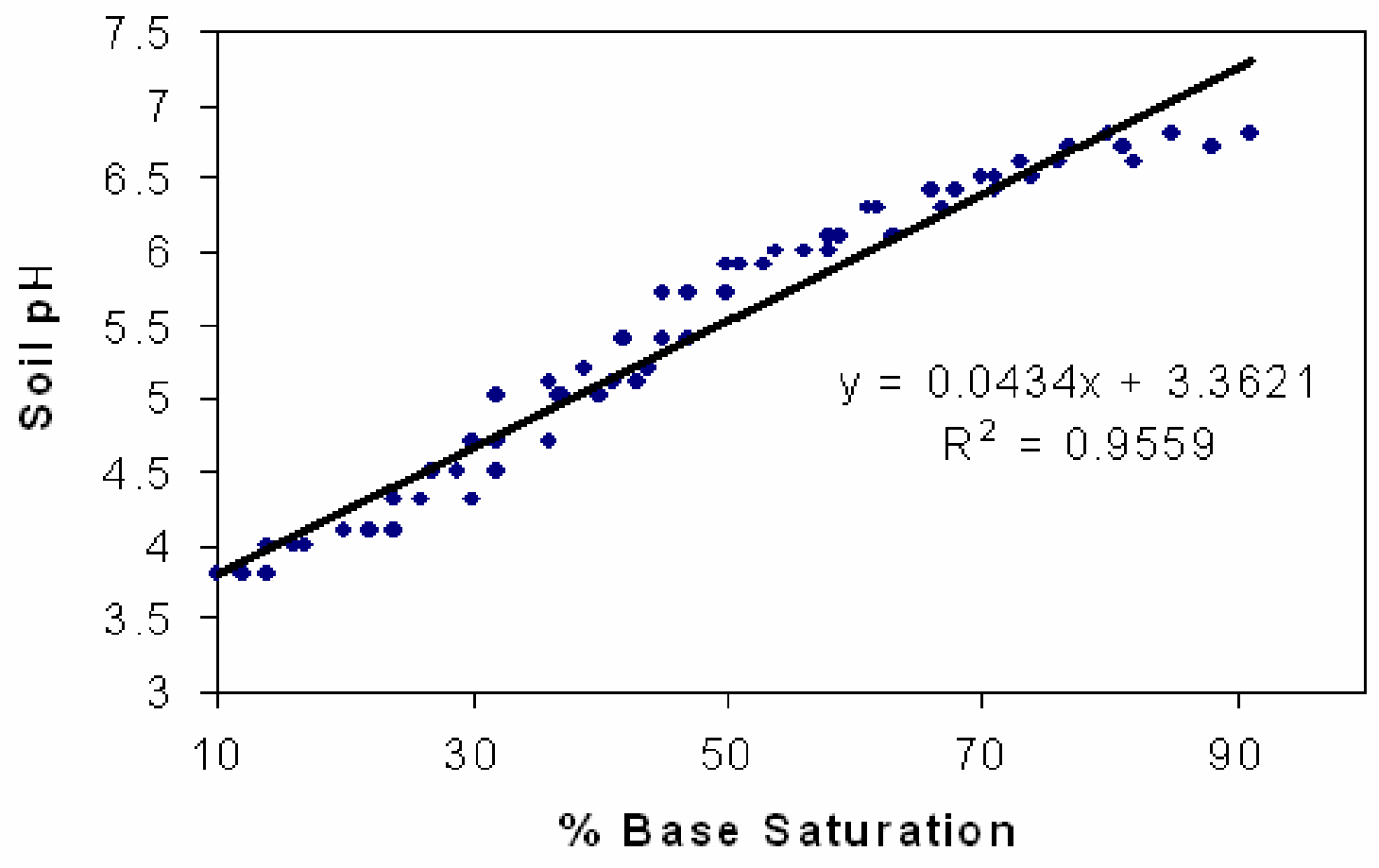

Fig. 1.2.3. Relationship between soil suspension $\mathrm{pH}$ and percent base saturation (Magdoff and Bartlett, 1985). 


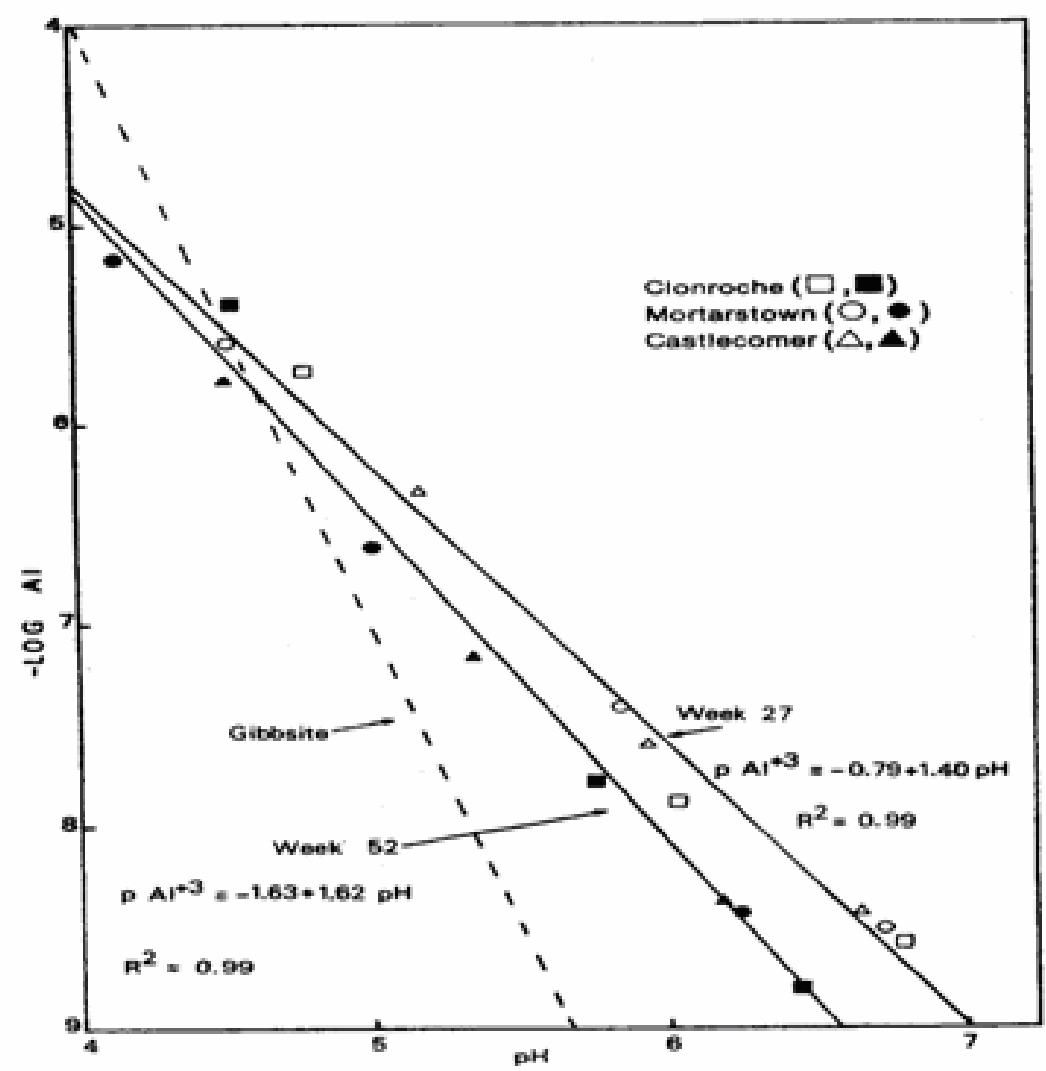

Fig. 1.2.4. Changes in $\mathrm{pAl}^{3+}$ with $\mathrm{pH}$ for Clonroche, Mortarstown and Castlecomer soil solutions obtained after 27 and 52 weeks of incubation. Solubility of gibbsite was calculated using a solubility product value of $10^{-34.05}$ (Curtin and Smillie, 1983).

Although it is widely accepted that the $\mathrm{pH}$ at which maximum plant yield occurs may vary depending on soil characteristics, the reasons for this differential responses are not well understood (Bolan et al., 2003). Although lime is an inexpensive soil amendment, because economic returns to pastures are relatively low and lime applications can be difficult on the steep soils of the region, it is important that lime application accurately reflect lime need especially for low input cropping systems. 


\subsection{Nitrogen and Phosphorus}

Nitrogen and phosphorus are the most frequently recommended fertilizers and limestone is the most commonly recommended soil amendment for agricultural soils. Most university soil testing laboratories, and many private laboratories, make fertilizer and soil amendment recommendations based on sufficiency levels (Eckert, 1987). Limestone is routinely prescribed at rates to increase soil $\mathrm{pH}$ to the range 6.2 to 6.6 and sufficiency level recommendations for phosphorus assume that soil $\mathrm{pH}$ is in the prescribed range. Therefore, it is important that lime recommendations made by soil test calibrations are accurate.

\subsubsection{Crop Response to Nitrogen and Phosphorus}

Overman and Scholtz (2003) developed relationships (response curves) among applied nitrogen, dry matter yield and plant $\mathrm{N}$ uptake and plant nitrogen concentration for bermudagrass (Fig.1.3.1). 


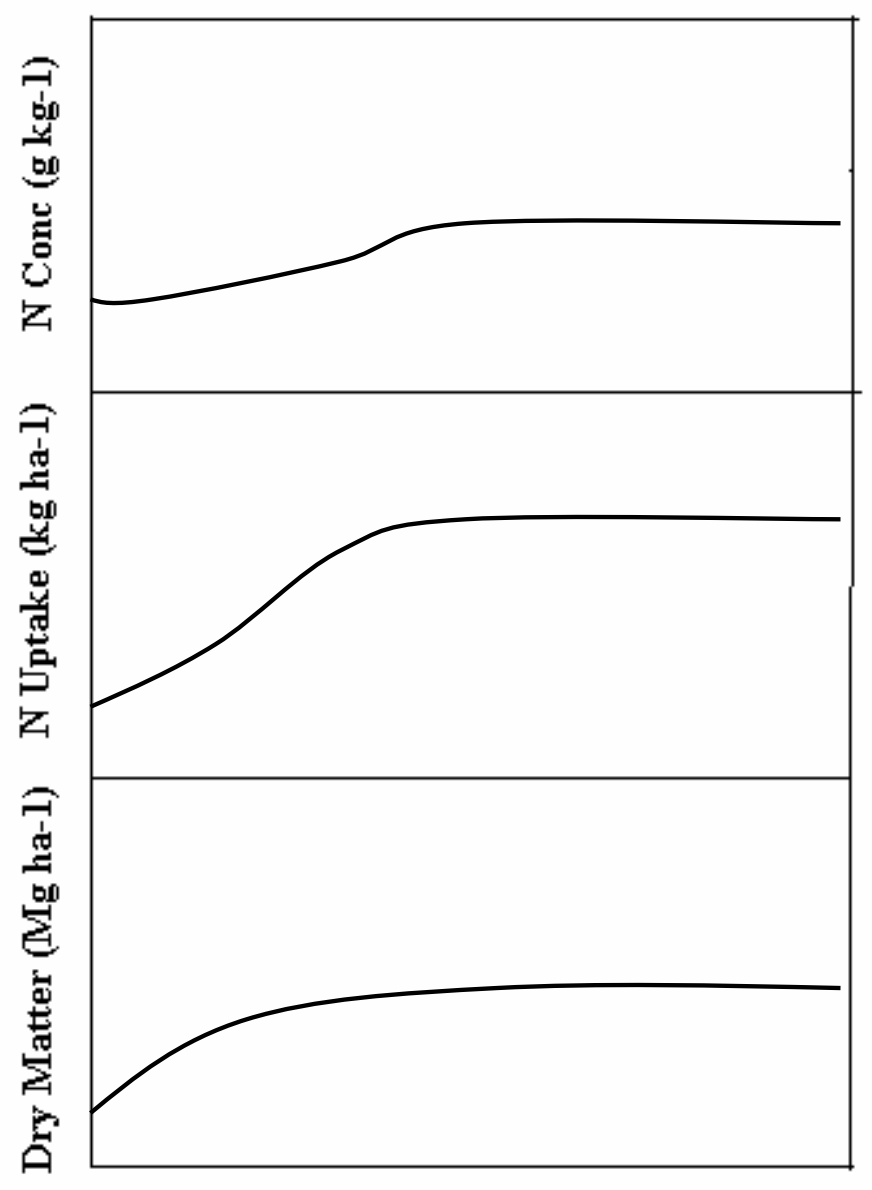

Applied N (kg ha-1)

Fig.1.3.1. Dependence of dry matter, plant $\mathrm{N}$ uptake, and plant $\mathrm{N}$ concentration on applied nitrogen for coastal Bermudagrass grown at Holland, VA (Overman and Scholtz , 2003)

Burman et al. (2004) found the synergistic effect of $P$ and thiourea enhanced the net photosynthesis, leaf area, chlorophyll content and nitrogen metabolism leading to significant improvement in plant growth and seed yield of cluster bean under water stress conditions (Table 1.3.1). The decline in seed yield was consistently lower in P treated cluster beans as compared to untreated plants. In a similar way, thiourea increased the seed yield of both control and water stressed plants. The combined application of $\mathrm{P}$ and 
thiourea exhibited the synergistic effects as seed yield and shoot dry mass increased by 34.2 and $27.3 \%$ respectively in water stressed treatments. Both P nutrition and thiourea application had a significant and favorable influence on plant growth and yield under drought conditions. Other studies have also shown that $\mathrm{P}$ nutrition under water deficits increased drought resistance and improved growth and yield (Gutierrez-Boem and Thomas 1998, Singh and Sale 2000).

Table 1.3.1. Influence of $\mathrm{P}$ and thiourea (TH) on seed yield and shoot dry matter (DM) of clusterbean under water stress (D) (Burman et al., 2004)

\begin{tabular}{llllll}
\hline Treatments & & \multicolumn{2}{c}{ Seed yield $\left(\mathrm{g} \mathrm{plant}^{-1}\right)$} & \multicolumn{2}{c}{ Shoot DM $\left(\mathrm{g} \mathrm{plant}^{-1}\right)$} \\
& & $\mathrm{P}_{\mathrm{o}}$ & $\mathrm{P}_{40}$ & $\mathrm{P}_{\mathrm{o}}$ & $\mathrm{P}_{40}$ \\
\hline \multirow{2}{*}{ Control } & $-\mathrm{TH}$ & 3.71 & 4.38 & 11.41 & 13.20 \\
& $+\mathrm{TH}$ & 4.46 & 4.91 & 12.72 & 13.94 \\
Drought & $-\mathrm{TH}$ & 3.15 & 3.15 & 7.77 & 9.02 \\
& $+\mathrm{TH}$ & 3.42 & 3.42 & 9.01 & 9.92 \\
& & & & & \\
LSD $_{0.05} \mathrm{D}$ & & & 0.27 & & 0.54 \\
LSD $_{0.05} \mathrm{P}$ & & & 0.27 & & 0.54 \\
LSD $_{0.05} \mathrm{TH}$ & & & 0.27 & & 0.54 \\
$\mathrm{D} \mathrm{X} \mathrm{P}$ & & $\mathrm{NS}$ & & $\mathrm{NS}$ \\
$\mathrm{D}$ X TH & & & $\mathrm{NS}$ & & $\mathrm{NS}$ \\
$\mathrm{P}$ X TH & & & $\mathrm{NS}$ & & $\mathrm{NS}$ \\
\hline
\end{tabular}

\subsubsection{Nitrogen by Phosphorus Interactions}

The decrease in the P supply reduced both organic and inorganic phosphate concentration of tomato leaves (Fig. 1.3.2a) while the concentrations of total and reduced leaf $\mathrm{N}$ continued to decrease with reduction of $\mathrm{N}$ supply (Fig. 1.3.2b). 

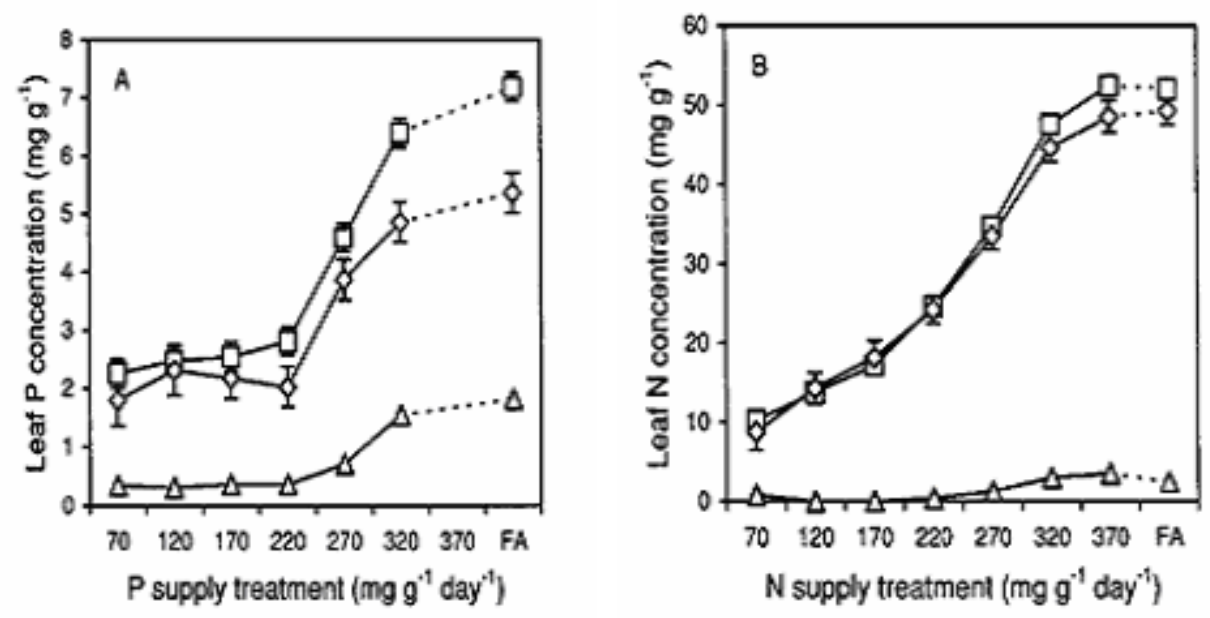

Fig. 1.3.2. Effect of $\mathrm{N}$ and $\mathrm{P}$ nutrition on leaf concentration of tomato leaves (Corine et al., 2003).

The relative growth rate (RGR) in tomato plants initially increased sharply with increasing plant $\mathrm{P}$ concentration but leveled off at higher plant $\mathrm{N}$ concentrations. But RGR increased gradually with increasing plant $\mathrm{N}$ concentration before it leveled off at higher Plant N concentrations (Corine et al., 2003).

Plant $\mathrm{N}$ concentration was also decreased with increasing P limitation (Fig. 1.3.3a). But there was a consistent increase in plant $\mathrm{P}$ concentration and stem $\mathrm{P}$ concentration with decreasing $\mathrm{N}$ supply (Fig. 1.3.3b). The explanation for the differences in response is mainly due to different roles of $\mathrm{N}$ and $\mathrm{P}$ in plant's energy metabolism. 

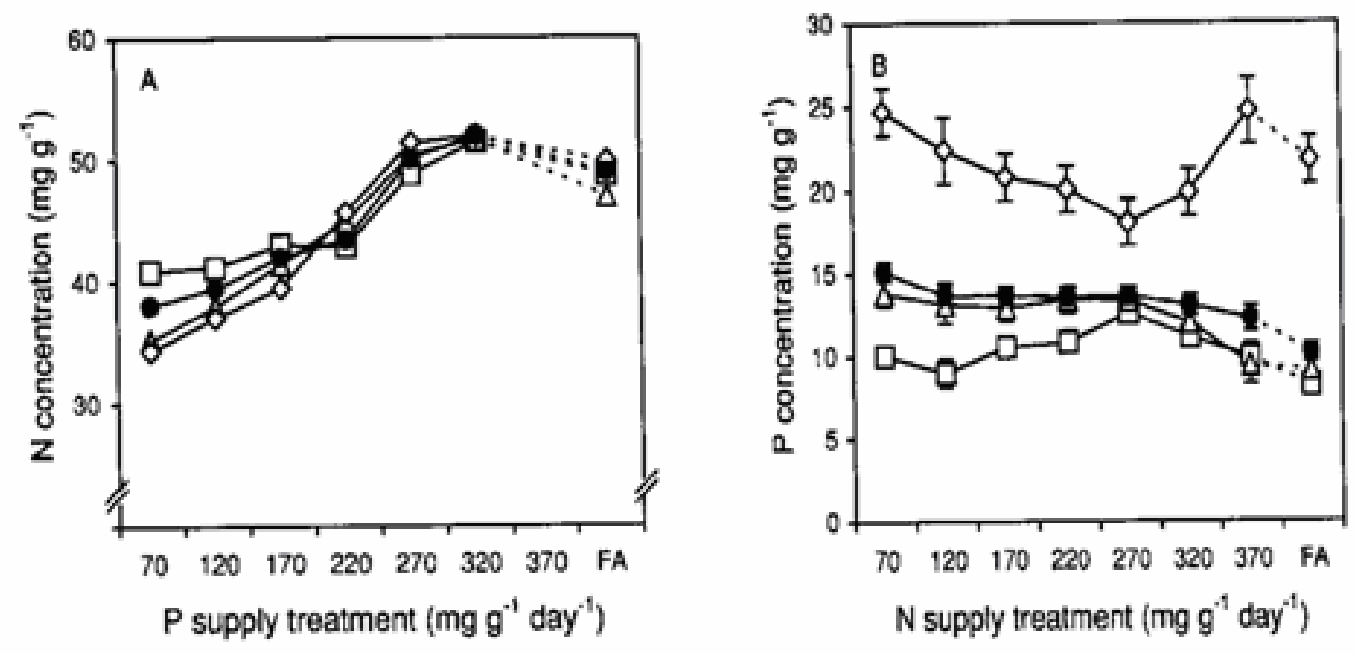

Fig. 1.3.3. Interactive effects of $\mathrm{N}$ and $\mathrm{P}$ nutrition in tomato leaves (Corine et al., 2003).

Mengel and Kirkby (1987) found that the accumulated inorganic phosphate and nitrate do not increase RGR but did increase the plant $\mathrm{P}$ and $\mathrm{N}$ concentration. An increase in $\mathrm{P}$ nutrition improved symbiotic $\mathrm{N}_{2}$ fixation in bean only at low $\mathrm{N}$ concentrations (Leidi and Navarro, 2000).

\subsubsection{Lime by Nitrogen Interactions}

Pasture growth and $\mathrm{N}$-accumulation responded to changes in soil acidity at the Bungendore site. There was also an increase in subterranean clover $\mathrm{N}$ yields, and pasture clover contents by addition of superphosphate in presence of lime at Bungendore site (Peoples et al., 1995) (Table1.3.2). 
Table1.3.2. Effect of lime and supersphosphate applications on pasture growth and accumulation of $\mathrm{N}$ in 1991. For each measurement, values followed by the same superscript letter do not differ significantly $(\mathrm{P}=0.05)$.

\begin{tabular}{|c|c|c|c|c|c|c|}
\hline $\begin{array}{l}\text { Site and } \\
\text { treatment }\end{array}$ & $\begin{array}{l}\text { Phosphorus } \\
\text { applied } \\
\left(\mathrm{kg} \mathrm{P} \mathrm{ha}^{-1}\right)\end{array}$ & $\begin{array}{l}\text { Pasture } \\
\text { dry matter } \\
\text { production } \\
\left(\mathrm{t} \mathrm{ha}^{-1}\right)\end{array}$ & $\begin{array}{l}\text { Non-clover } \\
\text { N yield } \\
\left(\mathrm{kg} \mathrm{P} \mathrm{ha}^{-1}\right)\end{array}$ & $\begin{array}{l}\text { Subterranean } \\
\text { clover } \\
\mathrm{N} \text { yield } \\
\left(\mathrm{kg} \mathrm{P} \mathrm{ha}^{-1}\right)\end{array}$ & $\begin{array}{l}\text { Pasture } \\
\text { clover } \\
\text { content* } \\
\text { ( } \% \mathrm{~N} \\
\text { basis) }\end{array}$ & $\begin{array}{l}\text { Total } \\
\text { pasture } \mathrm{N} \\
\left(\mathrm{kg} \mathrm{P} \mathrm{ha}^{-1}\right)\end{array}$ \\
\hline \multicolumn{7}{|l|}{ Bungendore } \\
\hline \multirow[t]{3}{*}{ Nil } & 0 & $3.19^{\mathrm{a}}$ & $33^{\mathrm{a}}$ & $23^{a}$ & $41^{\mathrm{a}}$ & $56^{\mathrm{a}}$ \\
\hline & 10 & $3.11^{\mathrm{a}}$ & $29^{\mathrm{a}}$ & $29^{\mathrm{a}}$ & $50^{\mathrm{ab}}$ & $58^{\mathrm{a}}$ \\
\hline & 20 & $3.26^{\mathrm{a}}$ & $28^{\mathrm{a}}$ & $39^{\mathrm{a}}$ & $58^{\mathrm{b}}$ & $67^{\mathrm{a}}$ \\
\hline \multirow[t]{3}{*}{ Lime } & 0 & $4.61^{b}$ & $46^{\mathrm{b}}$ & $38^{\mathrm{a}}$ & $45^{\mathrm{a}}$ & $84^{\mathrm{b}}$ \\
\hline & 10 & $5.18^{b}$ & $36^{\mathrm{ab}}$ & $70^{\mathrm{b}}$ & $66^{\mathrm{b}}$ & $106^{\mathrm{c}}$ \\
\hline & 20 & $5.07^{\mathrm{b}}$ & $40^{\mathrm{ab}}$ & $65^{\mathrm{b}}$ & $62^{b}$ & $105^{\mathrm{c}}$ \\
\hline \multicolumn{7}{|l|}{ Braidwood } \\
\hline $\mathrm{Nil}^{+}$ & $0-20$ & 3.18 & 53 & 4 & 6 & 57 \\
\hline Lime $^{+}$ & $0-20$ & 3.55 & 55 & 4 & 6 & 59 \\
\hline \multicolumn{7}{|l|}{ Beechworth } \\
\hline Nill $^{+}$ & $0-20$ & 3.08 & 37 & 18 & 33 & 55 \\
\hline Lime $^{+}$ & $0-20$ & 2.91 & 34 & 18 & 34 & 52 \\
\hline
\end{tabular}

* Subterranean clover $\mathrm{N}$ as a proportion of total pasture $\mathrm{N}$.

${ }^{+}$There was no significant effect o phosphorus treatment at either Braidworth; data averaged.

The poor performance of pastures has been attributed to acid soil effects on $\mathrm{N}_{2}$ fixation in mixed swards (Evans et al., 1980) and low P availability (Heylar and Anderson, 1970).

\subsubsection{Lime by Phosphorus Interactions}

Liming is a common practice to raise soil $\mathrm{pH}$ and increase phosphorus bioavailability (Sanchez and Uehara, 1980). However, P sorption has been shown to increase, decrease or remain unchanged with increasing $\mathrm{pH}$. Liming increased $\mathrm{P}$ sorption in three acid soils from southern Brazil up to pH 5.0 (Anjos and Rowell, 1987). Haynes 
(1982) found that mineral surfaces became increasingly negative with increasing $\mathrm{pH}$, resulting in more electrostatic repulsion and decreased P sorption. Reduced P sorption in a Cerrado Oxisol with an increase in $\mathrm{pH}$ was attributed to increased competition between hydroxyl and phosphate ions for specific adsorption on mineral surfaces (Smyth and Sanchez, 1980). Decreased P availability after liming was also attributed to the precipitation of insoluble calcium phosphates and / or increased P sorption on to newly formed hydroxyl $\mathrm{Al}$ surfaces formed following precipitation of exchangeable $\mathrm{Al}$ (Naidu et al., 1987; White and Taylor, 1977).

Lemare and Leon (1989) studied the effect of liming on the amounts of total and isotopically exchangeable phosphate adsorbed from solutions in five soils. Lime decreased the amount of phosphate sorbed at all concentrations in solution in an Oxisol and an inceptisol. In an Ultisol and an Inceptisol, lime increased the sorption of P at small concentrations and decreased it at large concentrations. In another context that contained spheroidal allophone and high organic matter, lime enhanced sorption at all concentrations of P. Phosphorus desorption exhibited the expected hysteresis between sorption and desorption at all three $\mathrm{pH}$ levels for each level of P loading (Sato and Comerford, 2005). Phosphorus sorption decreased up to 21 and 31\% when $\mathrm{pH}$ increased from 4.7 to 5.9 and 7.0, respectively. P desorption increased with an increase in soil $\mathrm{pH}$. Therefore, in this study, liming exhibited a dual trend of decreasing P sorption and increasing P desorption (Fig.1.3.4). 


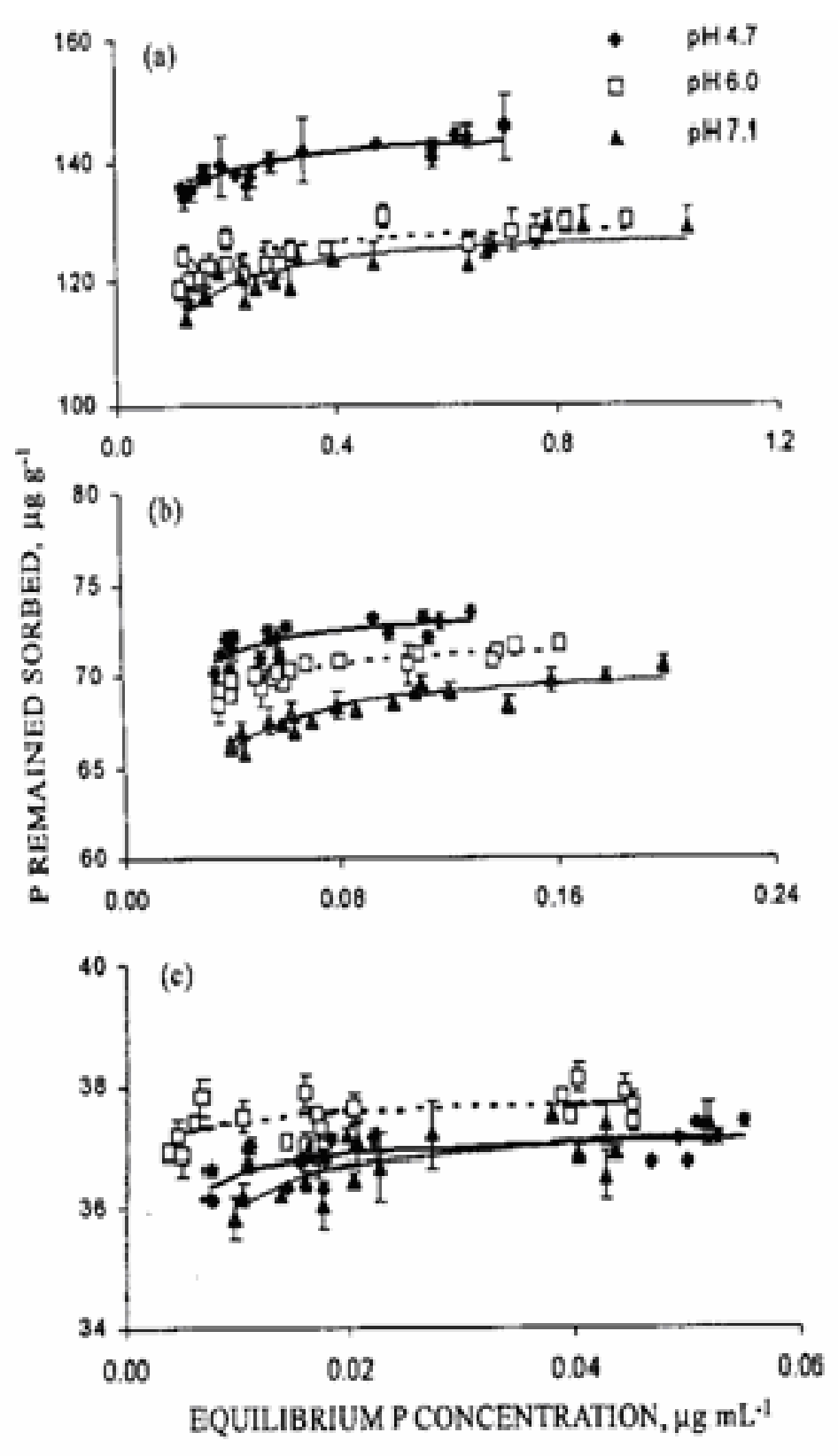

Figure1.3.4. Phosphorus desorption isotherms at three different soil $\mathrm{pH}$ levels with three different initial P addition levels (a) $180 \mu \mathrm{g} \mathrm{g}^{-1}$ of P. (b) $80 \mu \mathrm{g} \mathrm{g}^{-1}$. (c) $40 \mu \mathrm{g} \mathrm{g}^{-1}$ of P (Sato and Comerford, 2005)

Both phosphorus and lime applications had nearly equivalent additive effects on dry matter production in white clover due to improvement in plant available P (Bailey and Laidlaw, 1999). Both liming and addition of $\mathrm{P}$ treatments seemed to increase the pool of plant available $\mathrm{P}$ in soil either by supplying $\mathrm{P}$ directly or liming which stimulates 
organic P mineralization (Bailey, 1991). The effect of P uptake on enhancement of dry matter yield in white clover is shown in Fig. 1.3.5.

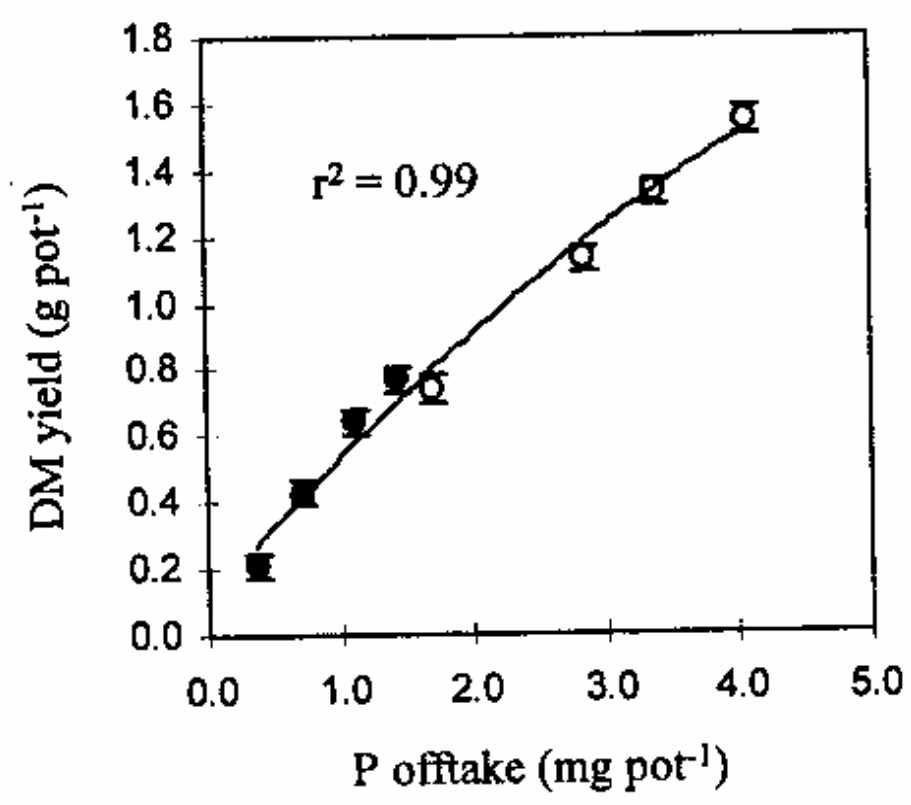

Fig. 1.3.5. Effect of $P$ uptake on dry matter yield in white clover (Bailey and Laidlaw, 1999).

Fox et al. (1964) found that small additions of lime to acidic Hawaiin soils greatly increased the uptake of fertilizer $\mathrm{P}$, but application of lime at $\mathrm{pH} 7.0$ reduced P-uptake. Lime additions caused a marked decrease in soluble P concentration. Although concentrations of phosphate in saturation paste extracts increased considerably with increased $\mathrm{P}$ addition, they decreased significantly with increasing lime addition (Table 1.3.3). 
Table 1.3.3. Effect of lime and $\mathrm{P}$ treatments on $\mathrm{P}, \mathrm{Al}, \mathrm{Mn}, \mathrm{Ca}, \mathrm{Mg}, \mathrm{K}$ and $\mathrm{Na}$ concentrations in saturation paste extracts (Haynes and Ludecke, 1981).

\begin{tabular}{|c|c|c|c|c|c|c|c|}
\hline \multirow[t]{2}{*}{ Treatment } & \multicolumn{3}{|c|}{ Concentration $(\mu \mathrm{M})$} & \multicolumn{4}{|c|}{ Concentration (mM) } \\
\hline & P & $\mathrm{Al}$ & $\mathrm{Mn}$ & $\mathrm{Ca}$ & $\mathrm{Mg}$ & $\mathrm{K}$ & $\mathrm{Na}$ \\
\hline $\mathrm{P}_{1} \mathrm{~L}_{0}$ & $1.9 \mathrm{c}$ & $296 d$ & $41 d$ & $1.38 \mathrm{a}$ & $0.78 \mathrm{~d}$ & $0.83 \mathrm{~d}$ & $1.59 \mathrm{c}$ \\
\hline $\mathrm{L}_{1}$ & $1.3 \mathrm{bc}$ & $82 \mathrm{c}$ & $17 \mathrm{c}$ & $5.63 b$ & $0.50 \mathrm{c}$ & $0.57 \mathrm{c}$ & $1.42 b$ \\
\hline $\mathrm{L}_{2}$ & $1.0 \mathrm{~b}$ & $56 b$ & $6 b$ & $6.44 \mathrm{c}$ & $0.27 b$ & $0.39 b$ & $1.28 \mathrm{ab}$ \\
\hline $\mathrm{L}_{3}$ & $0.6 \mathrm{a}$ & $31 \mathrm{a}$ & $4 a$ & $6.88 \mathrm{~d}$ & $0.20 \mathrm{a}$ & $0.32 \mathrm{a}$ & $1.00 \mathrm{a}$ \\
\hline $\mathrm{P}_{4} \mathrm{~L}_{0}$ & $81.6 \mathrm{~d}$ & $131 d$ & $35 d$ & $4.81 \mathrm{a}$ & $0.53 d$ & $0.67 \mathrm{c}$ & $1.44 \mathrm{c}$ \\
\hline $\mathrm{L}_{1}$ & $35.5 \mathrm{c}$ & $61 \mathrm{c}$ & $17 \mathrm{c}$ & $6.27 b$ & $0.30 \mathrm{c}$ & $0.34 b$ & $1.18 \mathrm{~b}$ \\
\hline $\mathrm{L}_{2}$ & $17.4 \mathrm{~b}$ & $52 b$ & $6 b$ & $7.53 \mathrm{c}$ & $0.24 b$ & $0.31 \mathrm{ab}$ & $1.12 \mathrm{~b}$ \\
\hline $\mathrm{L}_{3}$ & $11.9 \mathrm{a}$ & $30 \mathrm{a}$ & $4 a$ & $7.89 \mathrm{~d}$ & $0.17 \mathrm{a}$ & $0.28 \mathrm{a}$ & $0.92 \mathrm{a}$ \\
\hline
\end{tabular}

With more added lime, phosphorus extracted by various methods (water soluble, resin extractable, Morgan extractable and Williams extractable) decreased (Table 1.3.4).

Table1.3.4. Effect of lime and P treatments on the amount of available P extracted by various methods. (Haynes and Ludecke, 1981).

\begin{tabular}{lllllll}
\hline Treatment & \multicolumn{5}{c}{ P extracted by various methods $\left(\mu \mathrm{g} \mathrm{g}^{-1}\right)$} \\
& $\begin{array}{l}\text { Water } \\
\text { soluble }\end{array}$ & $\begin{array}{l}\text { Anion } \\
\text { exchange } \\
\text { resin }\end{array}$ & Morgan & Troug & Williams & Bray 1 \\
& & & & & \\
\hline & & & & & \\
$\mathrm{P}_{1} \mathrm{~L}_{0}$ & $11.7 \mathrm{c}$ & $24.6 \mathrm{~d}$ & $34.9 \mathrm{~d}$ & $15.1 \mathrm{a}$ & $73.3 \mathrm{~d}$ & $111 \mathrm{a}$ \\
$\mathrm{L}_{1}$ & $11.6 \mathrm{c}$ & $20.1 \mathrm{c}$ & $26.1 \mathrm{c}$ & $14.9 \mathrm{a}$ & $60.8 \mathrm{c}$ & $118 \mathrm{~b}$ \\
$\mathrm{~L}_{2}$ & $10.7 \mathrm{~b}$ & $17.8 \mathrm{~b}$ & $19.5 \mathrm{~b}$ & $14.9 \mathrm{a}$ & $57.7 \mathrm{~b}$ & $120 \mathrm{bc}$ \\
$\mathrm{L}_{3}$ & $8.3 \mathrm{a}$ & $10.4 \mathrm{a}$ & $12.4 \mathrm{a}$ & $15.0 \mathrm{a}$ & $45.9 \mathrm{a}$ & $124 \mathrm{c}$ \\
& & & & & & \\
$\mathrm{P}_{4} \mathrm{~L}_{0}$ & $96.8 \mathrm{~d}$ & $178 \mathrm{~d}$ & $145.0 \mathrm{~d}$ & $122 \mathrm{a}$ & $463 \mathrm{~d}$ & $413 \mathrm{a}$ \\
$\mathrm{L}_{1}$ & $91.5 \mathrm{c}$ & $165 \mathrm{c}$ & $99.0 \mathrm{c}$ & $121 \mathrm{a}$ & $412 \mathrm{c}$ & $419 \mathrm{~b}$ \\
$\mathrm{~L}_{2}$ & $77.9 \mathrm{~b}$ & $115 \mathrm{~b}$ & $89.1 \mathrm{~b}$ & $124 \mathrm{a}$ & $355 \mathrm{~b}$ & $437 \mathrm{c}$ \\
$\mathrm{L}_{3}$ & $49.0 \mathrm{a}$ & $98 \mathrm{a}$ & $64.9 \mathrm{a}$ & $121 \mathrm{a}$ & $283 \mathrm{a}$ & $446 \mathrm{~d}$ \\
\hline
\end{tabular}


The immediate source of $\mathrm{P}$ for growing crops is inorganic $\mathrm{P}$ in the soil solution. Generally, agricultural crops require up to $0.3 \mu \mathrm{g} \mathrm{P} \mathrm{ml}{ }^{-1}$ of soil solution (Russel, 1973). With increasing lime additions, available phosphate indices (i.e. water soluble, resin-, Morgan- and Williams-extractable) decreased significantly. Decrease was found in easily soluble P and 'Fe-bound' and to lesser extent 'Ca-bound' P fractions. The 'Reductant soluble P' (occluded) was not affected by lime additions, whereas an increase was observed in the 'Al-bound' form (Haynes and Ludecke, 1981). These different forms of phosphate were categorized based on the type of extractant (i.e. water, resin, Morgan and William, Troug, and Bray 1) used (Table. 1.3.5).

Table 1.3.5. Effects of lime and P treatments on the various inorganic soil P fractions (Haynes and Ludecke, 1981).

\begin{tabular}{cllcll}
\hline Treatment & \multicolumn{5}{c}{$\mathrm{P}$ extractable $\left(\mu \mathrm{g} \mathrm{g}^{-1}\right)$} \\
& $\begin{array}{l}\text { Easily } \\
\text { soluble }\end{array}$ & $\mathrm{Al}-$ bound & Fe- bound & $\begin{array}{l}\text { Reductant } \\
\text { soluble }\end{array}$ & $\mathrm{Ca}-$ bound \\
& & & $\left(\mu \mathrm{g} \mathrm{g}^{-1}\right)$ & & \\
$\mathrm{P}_{1} \mathrm{~L}_{0}$ & 4.8 & 36 & 40 & 11 & 3.5 \\
$\mathrm{~L}_{1}$ & 2.9 & 38 & 36 & 11 & 3.3 \\
$\mathrm{~L}_{2}$ & 1.4 & 41 & 34 & 11 & 2.8 \\
$\mathrm{~L}_{3}$ & 0.6 & 44 & 34 & 10 & 2.8 \\
& & & & & \\
$\mathrm{P}_{4} \mathrm{~L}_{0}$ & 34.9 & 324 & 135 & 11 & 7.6 \\
$\mathrm{~L}_{1}$ & 15.3 & 356 & 126 & 11 & 5.3 \\
$\mathrm{~L}_{2}$ & 6.8 & 387 & 113 & 11 & 5.7 \\
$\mathrm{~L}_{3}$ & 3.0 & 399 & 108 & 11 & \\
\hline
\end{tabular}

Correlations between available $\mathrm{P}$ and plant uptake were positive and significant despite weak or non-significant correlations between phosphate indices in soil and yield of two species (Table 1.3.6). The legume yield and P uptake increased with increasing 
lime rates. The best correlations were seen with Troug and Bray P which were the only indices that did not decrease with increasing lime rates.

Table1.3.6. Simple correlation coefficients (r) between extractable soil P and total yield and P uptake of lotus and white clover (Haynes and Ludecke, 1981).

\begin{tabular}{|c|c|c|c|c|}
\hline Soil test & Lotus yield & Lotus P uptake & Clover yield & Clover P uptake \\
\hline & $\mathrm{Mg} \mathrm{ha}^{-1}$ & $\%$ & $\mathrm{Mg} \mathrm{ha}^{-1}$ & $\%$ \\
\hline Troug & $0.68 * *$ & $0.88^{* * *}$ & $0.62 *$ & $0.86^{* * *}$ \\
\hline Bray & $0.63 * *$ & $0.86^{* * *}$ & 0.58 & $0.84 * * *$ \\
\hline Williams & 0.51 & $0.75^{* * *}$ & 0.47 & $0.70 * *$ \\
\hline Water soluble & 0.44 & $0.69 * *$ & 0.39 & $0.63 * *$ \\
\hline Resin extractable & 0.41 & $0.67 * *$ & 0.28 & $0.60 *$ \\
\hline Morgan & 0.25 & 0.51 & 0.08 & $0.61 *$ \\
\hline
\end{tabular}

Levels of significance shown: $* \mathrm{P} \leq 0.05 ; * * \mathrm{P} \leq 0.01$ and $* * * \mathrm{P} \leq 0.001$

Added lime increased the efficiency of P fertilization and also reduced the possibility of $\mathrm{P}$ pollution due to excessive $\mathrm{P}$ application. Increasing soil $\mathrm{pH}$ by liming reduced $\mathrm{P}$ concentration in soil solution $\left(\mathrm{P}_{\mathrm{li}}\right)$ and increased anion resin exchangeable $\mathrm{P}$ $\left(\mathrm{P}_{\mathrm{si}}\right)$. Added $\mathrm{P}$ increased $\mathrm{P}_{\mathrm{si}}$ linearly and produced a curvilinear decrease in $\mathrm{P}_{\text {li. }}$ (Figure 1.3.6) (Chen and Barber, 1990). In this study, as the $\mathrm{pH}$ increased, $\mathrm{P}$ was sorbed to exchangeable sites of newly formed surfaces and anion resin exchangeable P (Pi) increased. This would reduce $\mathrm{P}$ in soil solution, which would adversely affect $\mathrm{P}$ availability plants. So it is important to know the $\mathrm{pH}$ and determine the exact quantity of lime that causes $\mathrm{P}$ desorption sufficient to meet the P requirements of plants. These facts have to be considered when making fertilizer recommendations for acidic agricultural lands. 


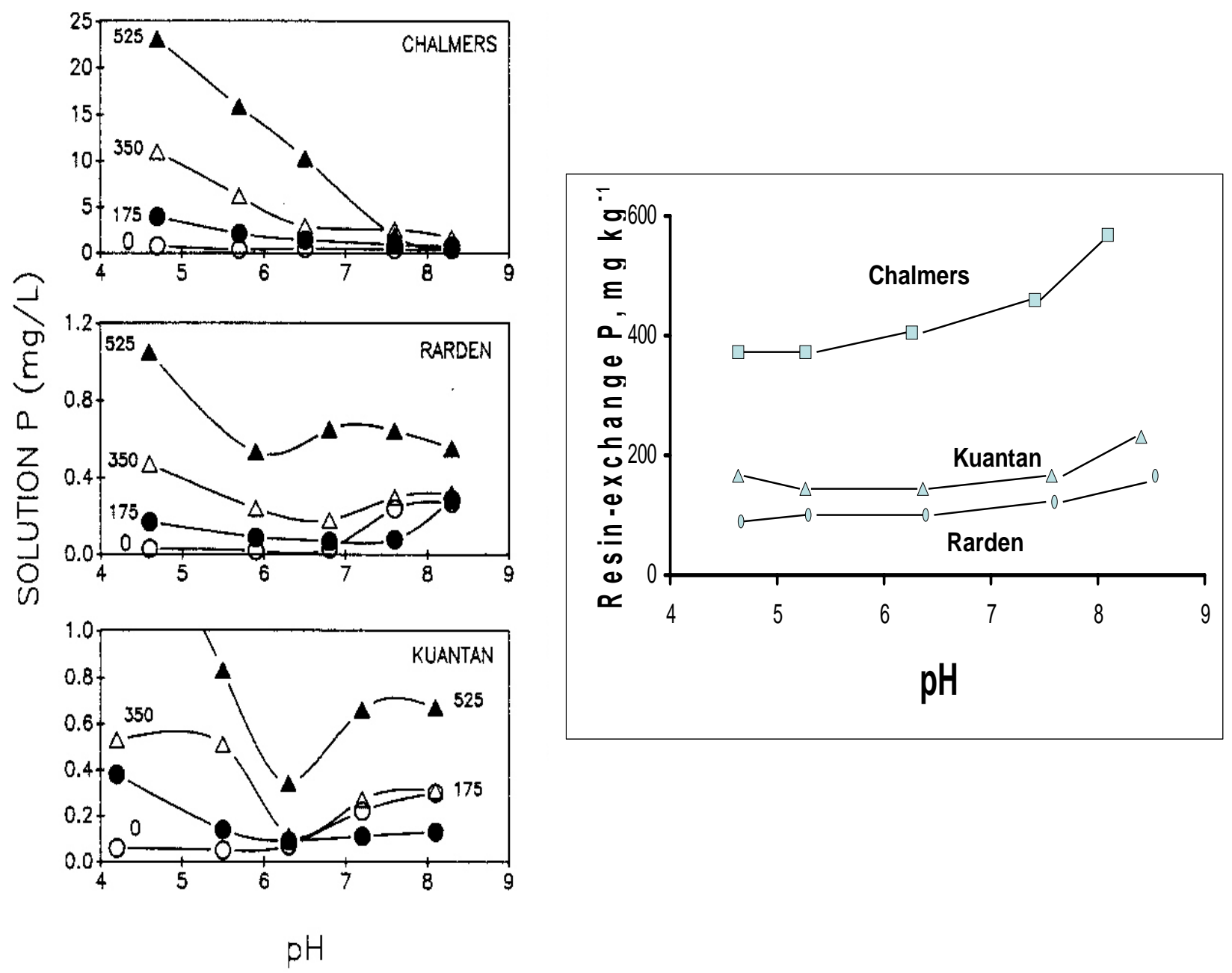

Fig. 1.3.6. Effect of soil $\mathrm{pH}$ and $\mathrm{P}$ rates on solution $\mathrm{P}$ and resin-exchange $\mathrm{P}$ (avg. of four rates of P) for three acid soils (Chen and Barber, 1990).

Liming had a P-sparing effect immediately after application, but thereafter may undergo complicated processes that negatively affect $\mathrm{P}$ bioavailability. There was an initial rapid release of $\mathrm{P}$ at different lime rates due to the $\mathrm{P}$-sparing effect, but subsequently the $\mathrm{P}$ concentration in the equilibrating solutions decreased, which indicates 
some resorption of $\mathrm{P}$ until equilibrium was attained after 2-3 days (Curtin and Smillie, 1984) (Fig. 1.3.7).

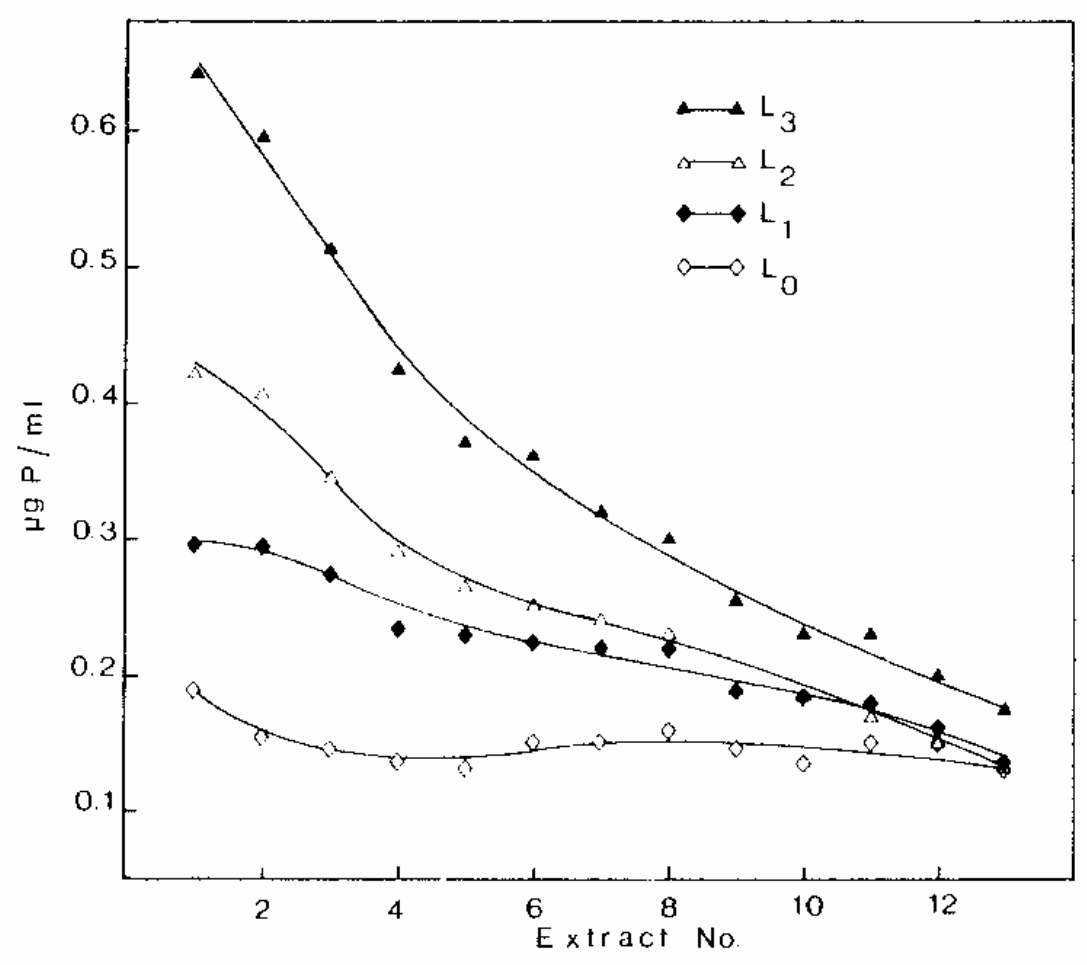

Fig. 1.3.7. Soil $\mathrm{P}$ desorption in an extraction sequence with $0.2 \mathrm{M} \mathrm{NaCl}$ at four lime levels (Curtin and Smillie, 1984).

As the $\mathrm{pH}$ of highly weathered soils increases, the concentration of phosphate in solution is generally observed to initially decrease, pass through a minimum for some time and then increase (Murrmann and Peech, 1969) (Fig. 1.3.8). This phenomenon is due to solubility of minimum phosphate in the $\mathrm{pH}$ range 5.5 to 6.5 and there is a close relationship between the effect of lime applications on the precipitation of exchangeable $\mathrm{Al}$ as amorphous hydroxides and the increased ability of soils to fix phosphate. If the soil 
$\mathrm{pH}$ increases above 6.5 to 7.0 , the hydroxyl-Al species become soluble due to sequential deprotonation to form negatively charged aluminum complexes like $\mathrm{Al}(\mathrm{OH})_{4}{ }^{-} \mathrm{Al}(\mathrm{OH})_{5}{ }^{2-}$ and $\mathrm{Al}(\mathrm{OH})_{6}{ }^{3-}$. These dissolved negatively charged hydroxyl-Al release previously sorbed phosphate. This process explains the phosphorus solubility curve in the figure 1.3.7 (Haynes, 1982).

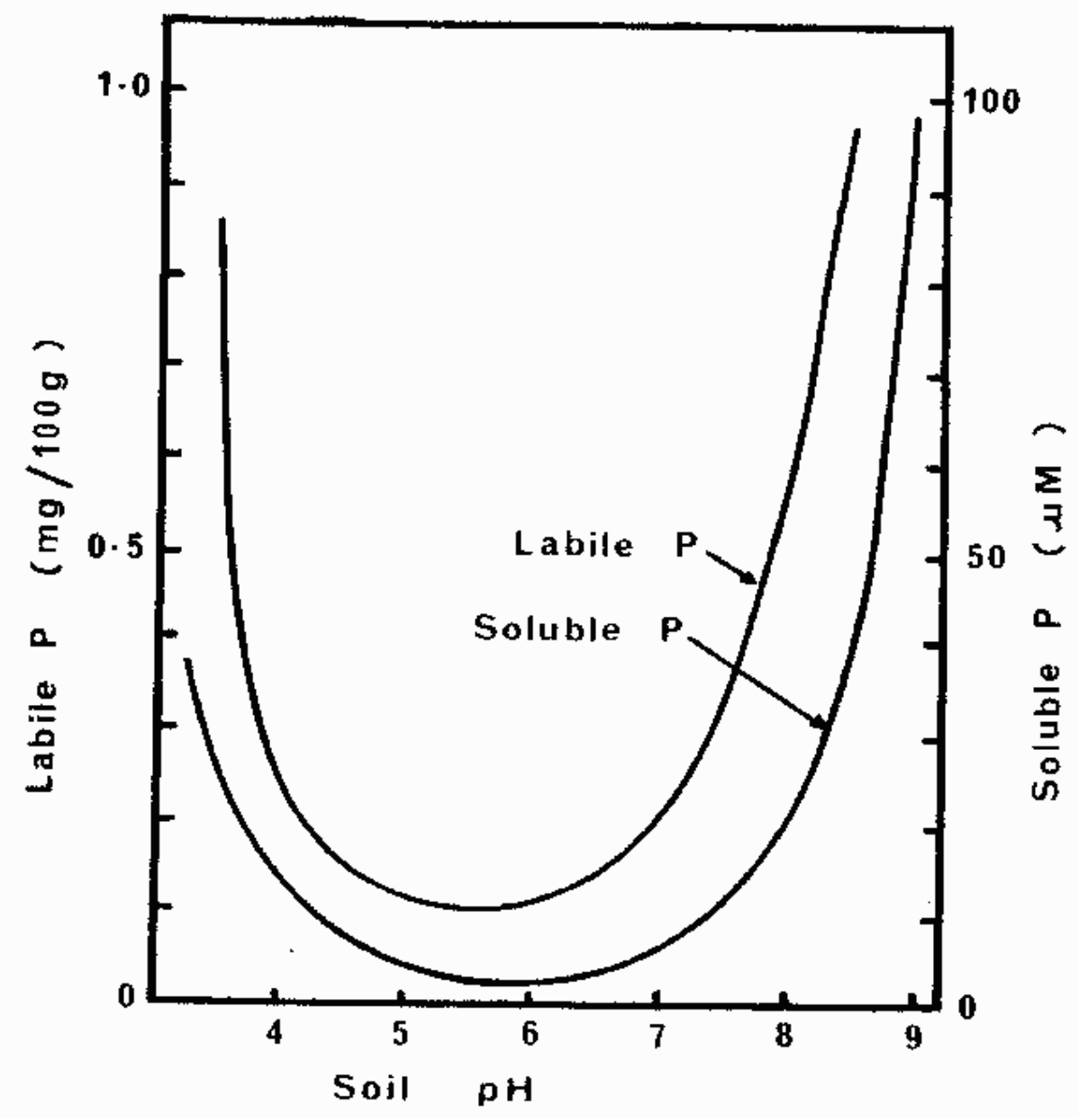

Fig. 1.3.8. Effect of soil $\mathrm{pH}$ on the $\mathrm{P}$ concentration in soil solution (Murrmann and Peech, 1969). 


\subsection{Soil Water}

Topography has a significant effect on soil formation and water potential. For example, the thickness of the soil profile is often determined by the nature of its position on the landscape. With identical rainfall and comparable parent material the soil is more moist on gentle slopes than on steeply sloping land and still moist or wet in valleys and depressions (Brady and Weil, 1999). Soils on steep slopes are generally shallow, stony and have weakly-developed profiles with less distinguished horizons due to rain-wash and surface runoff. Steep slopes and accelerated erosion cause a slow downward movement of soil mass under the influence of gravity which is known as soil creep and produces thick colluvial soil at the slope toe. Variation in water potential due to toposequence also plays a critical role in solublization and transport of minerals in the soil and thus should be considered while designing management practices for pastures. Fertilizer use efficiency is a function of available water (Fiez et al., 1994; GutierrezBoem and Thomas, 1998). Thus, water potential has an influence on the movement and availability of nutrients from applied fertilizers and amendments.

\subsubsection{Crop Response to Available Water}

The response of forage sorghum (Sorghum bicolor L.) to three irrigation treatments in semiarid environment was studied for two seasons in which the irrigation water at $8 \mathrm{~mm}_{\text {day }}{ }^{-1}$ was delivered every 7 (light frequent), 10 (moderate less frequent) and 13 (heavy infrequent) days. Averaged over two seasons, maximum dry matter yields were $16.3,11.8$, and 10.5 tonnes ha $^{-1}$ for frequent, intermediate, and infrequent irrigation regimes respectively (Saeed and Nadi, 1998) (Fig.1.4.1) 


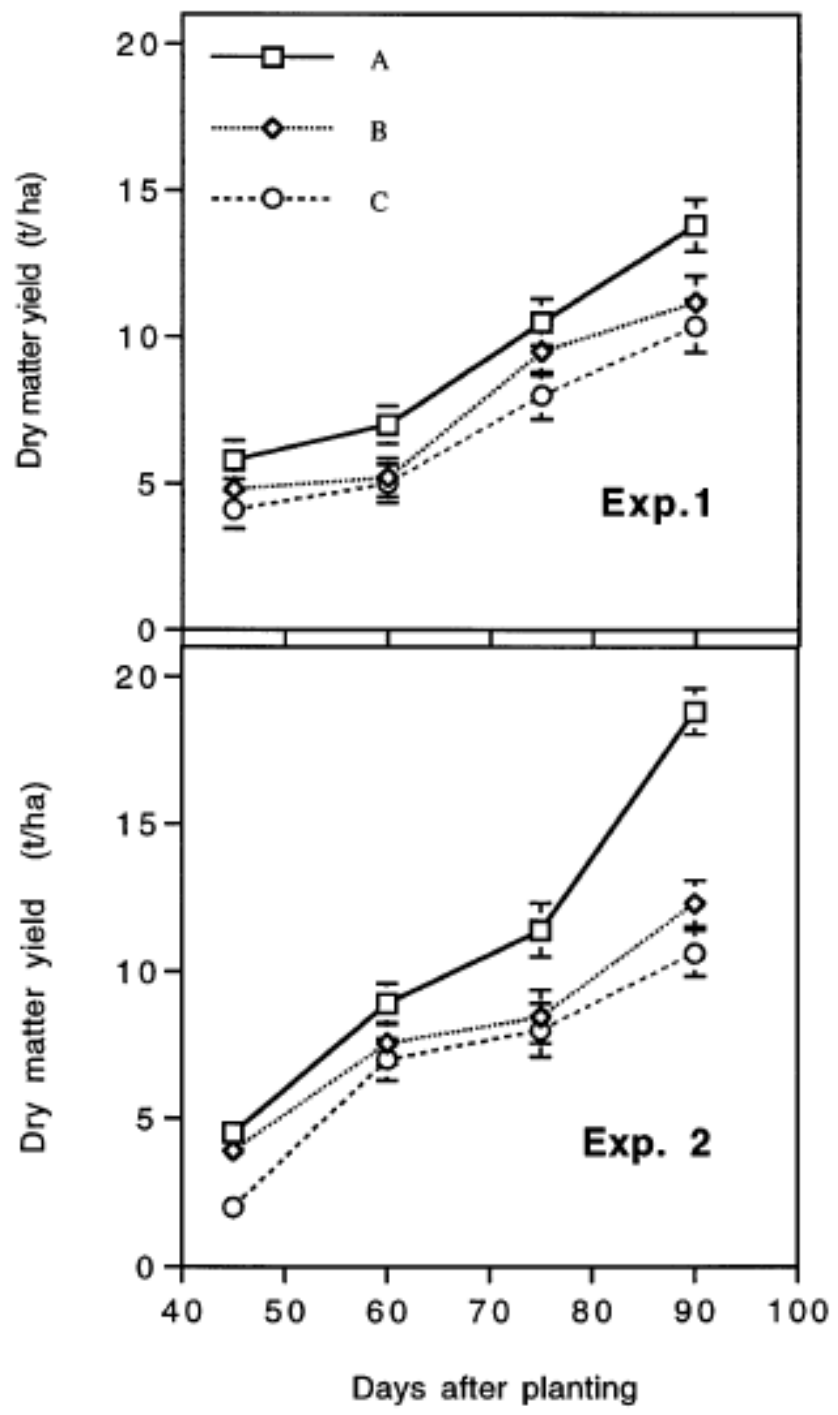

Fig.1.4.1. Average forage sorghum dry matter yield for four sampling occasions under the three water regimes (A (7 days), B (10 days), and C (13 days)) (Saeed and Nadi, 1998)

David (2004) found that dry matter yield of Kenaf (Hibiscus cannabinus L.) increased linearly with increases in available water and water use, with about $2000 \mathrm{~kg}$ ha $^{-}$ ${ }^{1} \mathrm{DM}$ yield produced with 274-mm water use, increasing to $6000 \mathrm{~kg} \mathrm{ha}^{-1}$ with $507 \mathrm{~mm}$ water use (Fig.1.4.2). 


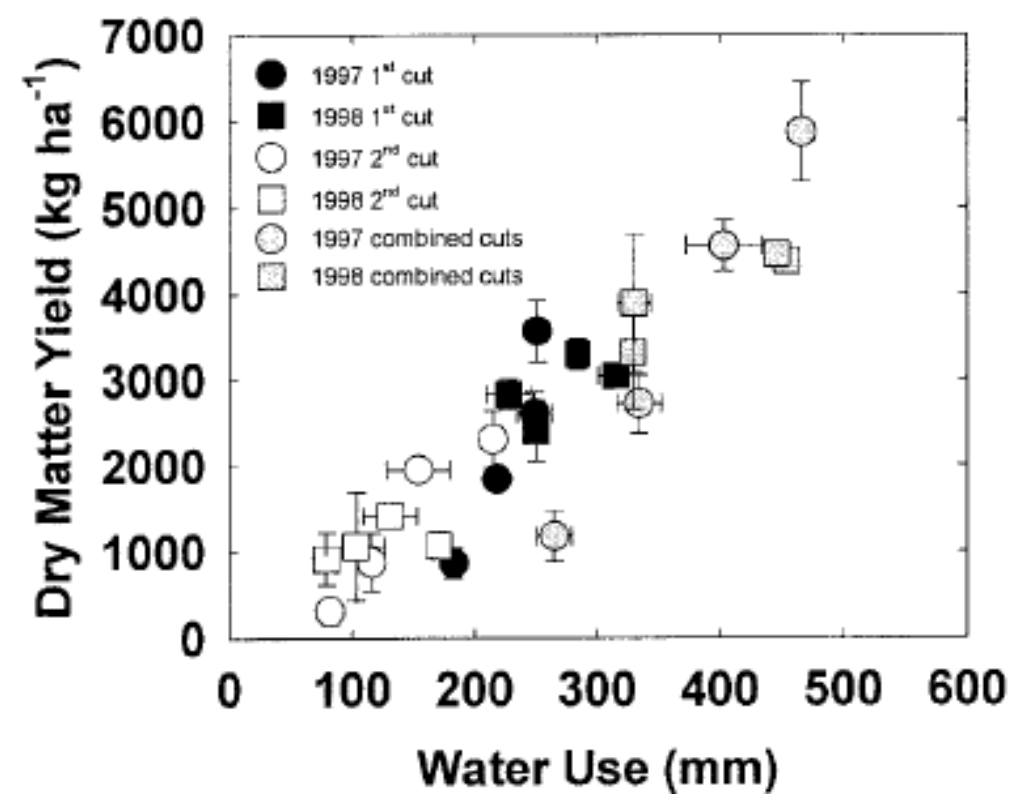

Fig.1.4.2. Dry matter yield vs water use for two cuttings of kenaf grown under an irrigation gradient at Akron, CO, in 1997 and 1998 (David, 2004)

\subsubsection{Water by Lime by Nitrogen by Phosphorus Interactions}

The energy state of water in the soil is important in the process of nutrient absorption by plants. The water potential of a soil is responsible for the dissolution of applied fertilizers and affects nutrient availability through its effects on mass flow and diffusion processes. Thus, the water potential of soil is crucial in governing the physical, chemical and microbiological processes of nutrients taking place in the soil system. Soil microbial activity is also affected by soil water potential, and microorganisms perform many of the nutrient transformations in soil.

Robinson (1957) studied N-dynamics in soil in response to different moisture levels and found that the rates of processes such as ammonification were reduced to one half at wilting point. Miller and Johnson (1964) determined that the optimum matric suction in soil for $\mathrm{N}$ mineralization ranged from 0.15 to 0.5 bar. The rates of 
ammonification and nitrification were significantly influenced by soil moisture content at tensions between 0.2 and 15 bars (Reichman et al., 1966). These two processes are essential to make soil nitrogen available to plants. Hopmans et al. (1980) showed that $\mathrm{N}$ mineralization in forest soils under two different plantings (pine and eucalyptus) was strongly dependent upon soil moisture content (Table 1.4.1).

Table 1.4.1. Effect of moisture content on N-mineralization in forest soils (Hopmans et al., 1980)

\begin{tabular}{llllllllll}
\hline Incubation & Forest type & Nitrogen & \multicolumn{5}{c}{ Moisture content \% } \\
\hline \multirow{2}{*}{ (days) } & & & 5 & 10 & 15 & 20 & 25 & 30 & 35 \\
& & Ppm & & & & & & & \\
& & $\mathrm{NH}_{4}^{+}$ & 40 & 70 & 83 & 76 & 88 & 88 & 43 \\
& $\mathrm{NO}_{3}^{-}$ & 1 & 2 & 3 & 15 & 8 & 2 & 1 \\
& & Total & 41 & 72 & 86 & 91 & 96 & 84 & 44 \\
90 & & & & & & & & \\
& \multirow{4}{*}{ Eucalyptus } & $\mathrm{NH}_{4}^{+}$ & 99 & 91 & 105 & 135 & 126 & 99 & 100 \\
& & $\mathrm{NO}_{3}^{-}$ & 1 & 4 & 3 & 2 & 5 & 11 & 1 \\
& & Total & 100 & 95 & 108 & 137 & 131 & 110 & 101 \\
\hline
\end{tabular}

Nitrate concentration was reduced by $22 \%$ in lettuce when the water potential was reduced from $-30 \mathrm{kPa}$ to $-100 \mathrm{kPa}$ (Aggelides et al., 1999). The optimum soil water potential for gross $\mathrm{N}$ mineralization and nitrification, microbial and enzymatic activities was -10 $\mathrm{kPa}$, compared with $0 \mathrm{kPa}$ and $-80 \mathrm{kPa}$ (Zaman et al., 1999).

Pier and Doerge (1995) observed a pronounced positive water x N interactions in watermelon with maximum fruit yields occurred at rates of applied $\mathrm{N}$ between 200 and $270 \mathrm{~K} \mathrm{ha}^{-1}$ at mean soil water tension of $6 \mathrm{kPa}$ (Fig. 1.4.3). 


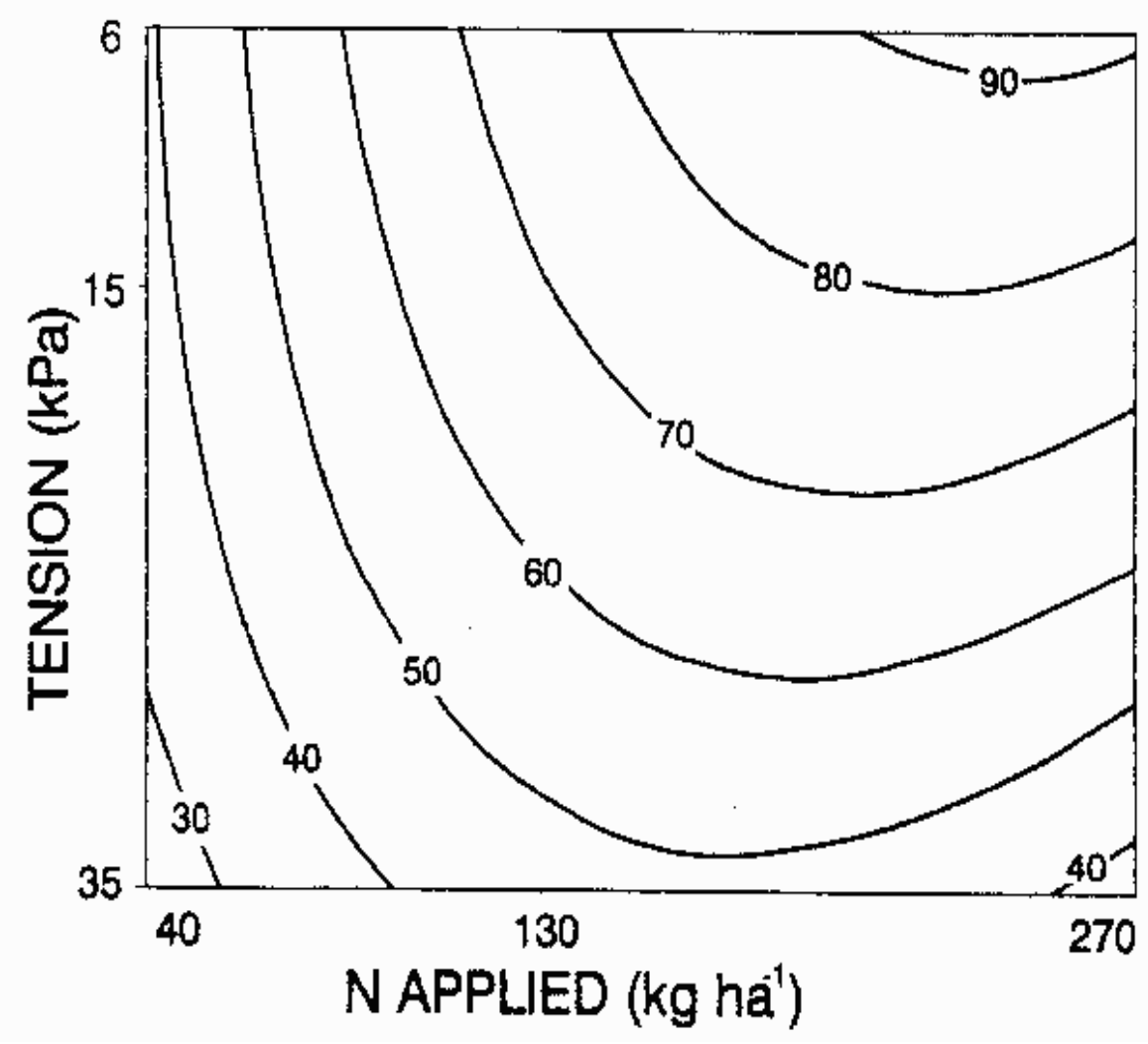

Fig. 1.4.3. Predicted marketable watermelon yield, Contour line units are $\mathrm{Mg} \mathrm{ha}^{-1}$. Response surface lack of fit: $\mathrm{P}<0.175$ (Pier and Doerge, 1995)

Soil moisture had a considerable effect on the mobility and uptake of phosphorus by corn (Mederski and Wilson, 1960). Olsen et al. (1965) observed that P uptake by corn seedling roots decreased by $50 \%$ as soil moisture decreased from that held at a water potential of $-33 \mathrm{kPa}$ to that at $-300 \mathrm{kPa}$ and lower moisture reduced $\mathrm{P}$ diffusion through the soil to the root surface. Dunham and Nye (1976) noted a significant reduction in P uptake by onion (Allium cepa L.) seedlings as soil moisture was reduced. An increase in water potential from $-10 \mathrm{kPa}$ to $-0.1 \mathrm{kPa}$ resulted in an increase of between $38 \%$ and $239 \%$ in the concentration of $\mathrm{KCl}$-extractable inorganic $\mathrm{P}$ in the soil, depending on time 
and incubation temperature (Grierson et al., 1999). Mackay and Barber (1985) showed that as soil moisture was raised from 0.22 to 0.27 (volumetric basis), P-uptake by corn increased by 55 to $70 \%$ (Table 1.4 .2 ).

Table 1.4.2. Influence of soil moisture content on $\mathrm{P}$ uptake by corn.

\begin{tabular}{|c|c|c|c|c|c|c|c|c|c|}
\hline \multicolumn{10}{|c|}{ Moisture levels } \\
\hline & \multicolumn{3}{|c|}{ M0 (0.22) } & \multicolumn{3}{|c|}{ M1 (0.27) } & \multicolumn{3}{|c|}{ M2 (0.32) } \\
\hline Soil types & S0 & S1 & S2 & S0 & $\mathrm{S} 1$ & $\mathrm{~S} 2$ & S0 & $\mathrm{S} 1$ & S2 \\
\hline $\begin{array}{l}\text { Total plant wt } \\
\text { g Pot }^{-1}\end{array}$ & 1.76 & 3.39 & 7.75 & 2.52 & 4.86 & 8.74 & 2.44 & 4.35 & 7.28 \\
\hline $\begin{array}{l}\text { P uptake } \\
\mu \text { mol Pot }^{-1}\end{array}$ & 150 & 229 & 477 & 271 & 381 & 741 & 226 & 352 & 611 \\
\hline \multicolumn{10}{|c|}{ Significance of F values from Analysis of variance } \\
\hline \multicolumn{4}{|c|}{ Sources of variation } & \multicolumn{3}{|c|}{ Plant uptake } & \multicolumn{3}{|c|}{ P- uptake } \\
\hline \multicolumn{4}{|c|}{ Moisture (M) } & \multicolumn{3}{|c|}{$* *$} & \multicolumn{3}{|c|}{$* *$} \\
\hline \multicolumn{4}{|l|}{ Soil (S) } & \multicolumn{3}{|c|}{$* *$} & \multicolumn{3}{|c|}{$* *$} \\
\hline \multicolumn{4}{|l|}{$\mathrm{MX} \mathrm{S}$} & \multicolumn{3}{|c|}{$* *$} & \multicolumn{3}{|c|}{$* *$} \\
\hline
\end{tabular}

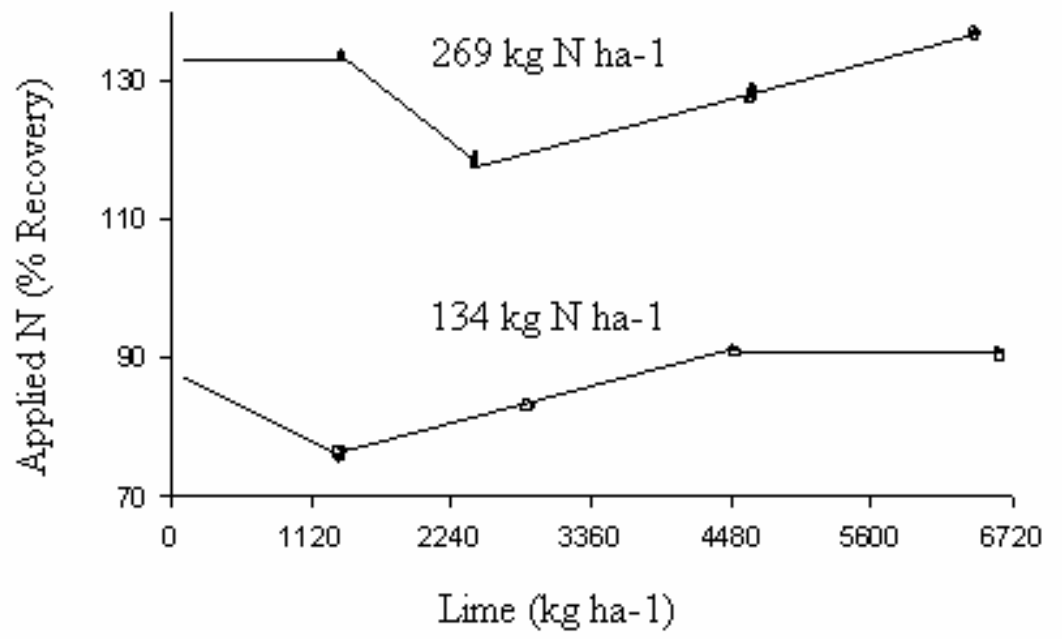

Fig. 1.4.4. Recovery of applied N on Kachemak silt loam (Winston et al., 1976) 
Liming affects both chemical and microbial transformation of nitrogen in soils. The efficiency of nitrification inhibitors decreases with the addition of lime due to increase in activity of nitrifiers and general microbial activity resulting in rapid biodegradation of nitrification inhibitors (Slangen and Kerkhoff, 1984). Nyborg and Hoyt (1978) found a substantial increase in nitrogen availability by liming which may be due to microbial induced organic $\mathrm{N}$ mineralization. Timothy grass (Phleum pretense $\mathrm{L}$.) showed increased recovery of $\mathrm{N}$ at both higher $(269 \mathrm{~kg} / \mathrm{ha})$ and lower rates $(134 \mathrm{~kg} / \mathrm{ha})$ in response to liming on Kachemak silt loam (Winston et al., 1976) (Fig.1.4.4). Lyngstad (1992) also observed that when soil $\mathrm{pH}$ was raised to 7.0 or above by application of lime, considerable organic $\mathrm{N}$ mineralization $\left(\mathrm{mg} \mathrm{kg}^{-1}\right)$ occurred in soils (Table 1.4.3). Igue et al. (1970) noted a significant positive response of wheat grain yield to phosphorus and lime application. The P-sparing effect of liming resulted in an increase in concentration of $\mathrm{P}$ in plant tissue as well as an increase in dry matter production of perennial ryegrass (Helyar and Anderson, 1971; Bailey and Steven, 1989) (Fig. 1.4.5).

Table 1.4.3. Liming effect on N-mineralization in soils from six year pot experiment (Lyngstad, 1992)

\begin{tabular}{lllllll}
\hline & \multicolumn{5}{c}{$\mathrm{CaO}\left(\mathrm{t} \mathrm{ha}^{-1}\right)$} \\
Year & 0 & 1.8 & 3.7 & 5.5 & 11.7 & LSD \\
\hline$n^{\text {st }}$ & 53 & 59 & 67 & 75 & 99 & 9 \\
$2^{\text {sd }}$ & 55 & 59 & 63 & 68 & 82 & 5 \\
$3^{\text {rd }}$ & 62 & 64 & 68 & 70 & 78 & 5 \\
$4^{\text {th }}$ & 65 & 69 & 68 & 68 & 70 & 4 \\
$5^{\text {th }}$ & 61 & 66 & 63 & 62 & 66 & 5 \\
6 th & 67 & 70 & 69 & 68 & 67 & 5 \\
\hline
\end{tabular}




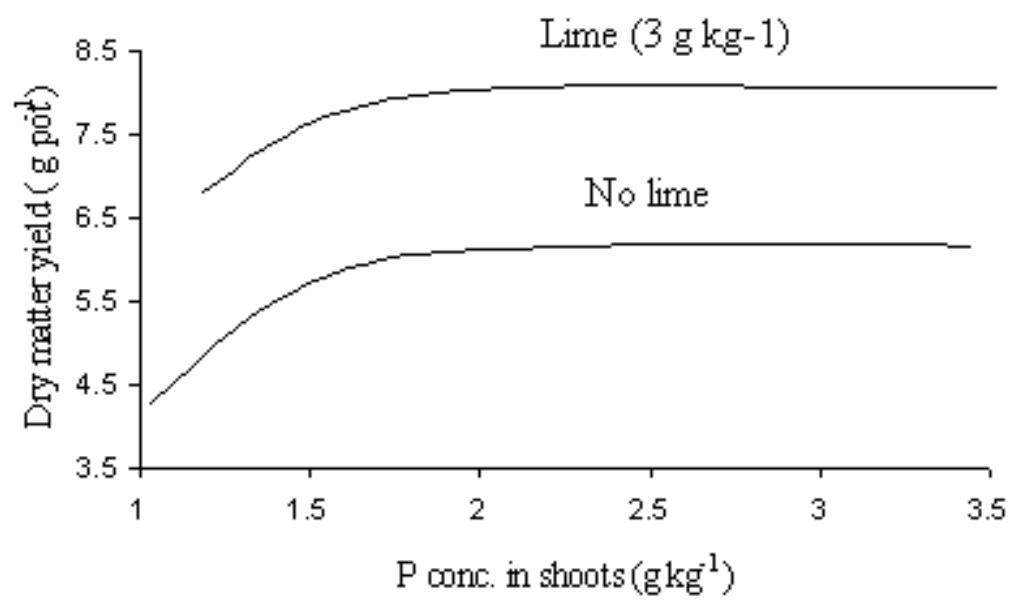

Fig.1.4.5. Effect of lime application on P-uptake by perennial ryegrass (Helyar and Anderson, 1971)

The mobilization of applied $\mathrm{P}$ was enhanced and more available to the crop with even a low lime dose (Bazegskii et al., 1976). Leaf analysis showed a pronounced increase in P concentration due to liming in soybean, sunflower and beans (Van Raij and Quaggio, 1990). Naidu et al. (1990) observed that the adsorption of phosphate reduced the soil positive charge at low $\mathrm{pH}$ and increased negative charges at high $\mathrm{pH}$. The net number of surface charge per unit of phosphate adsorbed varied with $\mathrm{pH}$ and appeared to depend on the mineralogy of the soil (Fig. 1.4.6). 


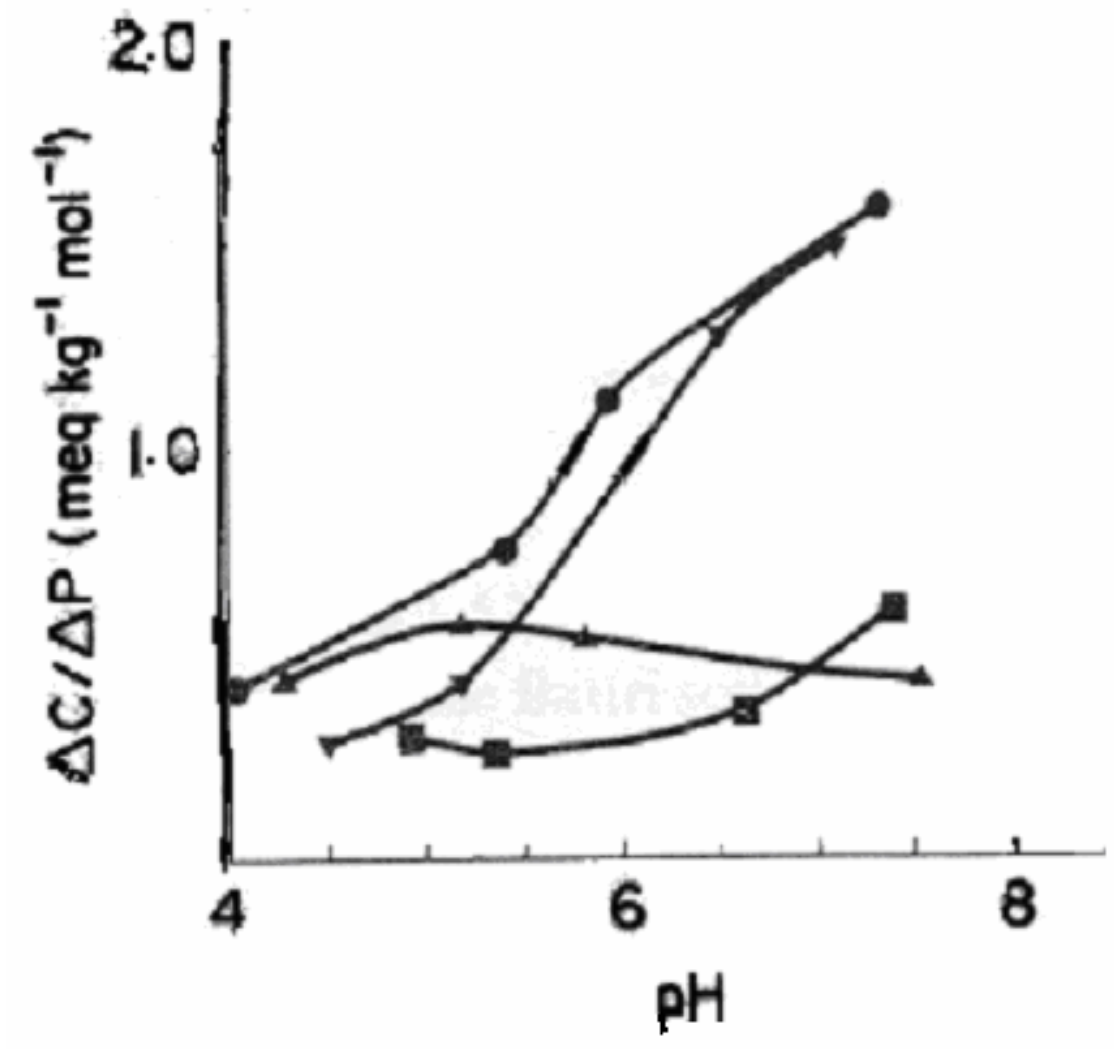

Fig.1.4.6. Net charge per mole of added $\mathrm{P}$ at different $\mathrm{pH}$ values in four different soils (Naidu et al., 1990)

Addition of phosphorus increased corn yield in all cropping seasons but the magnitude decreased as soil pH increased (Ernani et al., 2000). The availability and movement of phosphorus in the soil from added fertilizer is primarily influenced by moisture content of soil. The ability of plants to cope with mild water stress was enhanced by adequate $\mathrm{P}$ nutrition from fertilizers or manures and $\mathrm{P}$ uptake was affected by applied P, but not by water stress (Gutierrez-Boem et al., 1998) (Table 1.4.4). 
Table 1.4.4. Influence of $P$ application on water use efficiency (WUE) of plants under stressed conditions (Gutierrez-Boem et al., 1998).

\begin{tabular}{|c|c|c|c|c|}
\hline \multirow{3}{*}{$\begin{array}{l}\mathrm{P} \text { treatment } \\
\mathrm{mg} \mathrm{P} \mathrm{kg}^{-1} \text { soil }\end{array}$} & \multicolumn{2}{|c|}{ Shoot dry weight } & \multicolumn{2}{|c|}{ Shoot $\mathrm{P}$ conc. } \\
\hline & Well watered & Stressed & Well watered & Stressed \\
\hline & \multicolumn{2}{|c|}{ mg plant $\mathrm{g}^{-1}$} & \multicolumn{2}{|c|}{$\mathrm{mg} \mathrm{P} \mathrm{g}^{-1}$} \\
\hline P0 & 317 & 293 & 0.36 & 0.36 \\
\hline P10 & 485 & 442 & 0.66 & 0.70 \\
\hline $\mathrm{P} 20$ & 565 & 521 & 0.90 & 0.92 \\
\hline Mean & 455 & 419 & 0.64 & 0.67 \\
\hline Contrasts & & & & \\
\hline P0 vs. P10 \& P20 & & $* *$ & & $* *$ \\
\hline $\mathrm{P} 10$ vs. $\mathrm{P} 20$ & & $* *$ & & $* *$ \\
\hline
\end{tabular}

** Significant at the 0.01 probability level.

Application of $26.2 \mathrm{~kg} \mathrm{P} \mathrm{ha}^{-1}$ to pea (Pisum sativum $L$ ) resulted in a marked improvement in yield, nutrient uptake and water use efficiency (Kasturikrishna and Alhlawat, 1999). The combination of N, P and organic fertilizer significantly improved winter wheat yield and its water use efficiency even at lower moisture regimes (Cao, 2000). Thus, the variation in water status along slope and its interactions with applied fertilizers and amendments should be considered when making recommendations for undulating pasture lands.

\subsection{Summary}

The success of a liming program is dependent on the accuracy of the lime recommendation, which in turn depends on the quality of the underlying correlations and calibrations. Expensive large-scale field calibration experiments are rarely conducted anymore. The relatively low economic returns from pastures, especially in West Virginia make it even more unlikely that a calibration experiment will be conducted. Therefore any improvements in lime recommendations of quick tests have to be made from lime correlations with reference method (lime incubation studies or direct calcium hydroxide 
solution). Moreover, it is unlikely that a single lime correlation can accurately identify appropriate lime rates for all soils. Hence, one of the objectives of this study was to improve the accuracy of lime predictions by quick tests by accounting for soil order and by developing equations based on lime correlations for acidic pasture soils of West Virginia. Following development of accurate lime recommendations using quick tests, it is necessary to understand how the applied lime interacts with soil physical and chemical characteristics such as water potential, $\mathrm{N}$ and $\mathrm{P}$ levels to ultimately affect the productivity of grasslands.

Any pasture system needs appropriate agronomic practices to maximize productivity. Management of acidic pasture soils of Appalachian region will benefit from accurate and rapid methods of characterizing soil and nutrient factors that influence production. Among these factors, water potential, $\mathrm{pH}, \mathrm{N}$ and $\mathrm{P}$ levels were recognized as most critical to successfully maximize grassland productivity. So, following development of an accurate quick tests to determine lime requirement in the first experiment, the second objective of this research was to determine the optimal $\mathrm{pH}, \mathrm{N}$ and $\mathrm{P}$ needs as a function of water potential for bluegrass alone and a bluegrass - white clover mixture. 


\subsection{REFERENCES}

Abruna, F., and J.V. Chandler. 1955. Refinement of a quantitative method for determining the lime requirements of soils. J. Agri. Univ. Puerto Rico. 39:41-45. (Abstract only)

Adams, F. 1984. Crop response to lime in the Southern United States. p.211-259. In F. Adams (ed.) Soil Acidity and Liming. American Society of Agronomy. Madison, WI, USA.

Adams, F., and C.E. Evans. 1962. A rapid method for measuring lime requirement of Red-Yellow Podzolic soils. Soil Sci. Soc. Am. Proc. 26:355-357.

Aggelides, S., I. Assimakopoulos, P. Kerkides, and A. Skondras. 1999. Effects of soil water potential on the nitrate content and the yield of lettuce. Commun. Soil Sci. Plant Anal. 30:235-243.

Aitken, R.L., P.W. Moody, and P.G. Mckinley. 1990. Lime requirement of acidic Queensland soils. II. Comparison of laboratory methods for predicting lime requirement. Aust. J. Soil Res. 28:703-15.

Alabi, K.E., R.C. Sorensen, D. Knudsen, and O.H. Rehm. 1986. Comparison of several lime requirement methods on coarse textured soils of Northeastern Nebraska. Soil Sci. Soc. Am. J. 50:937-941.

Anjos, J.T, and D.L. Rowell. 1987. The effect of lime on phosphorus adsorption and barley growth in three acid soils. Plant and Soil 103: 75-82. 
Bailey, J.S. 1991. A re-examination of phosphorus-lime interactions in perennial ryegrass. Plant and Soil 135:185-196.

Bailey, J. S., and A.S. Laidlaw. 1999. The interactive effects of phosphorus, potassium, lime and molybdenum on the growth and morphology of white clover (Trifolium repens L.) at establishment. Grass and Forage Sci. 54:69-76.

Bailey, J.S., and R.J. Steven. 1989. Factors explaining variable lime responses in pastures: calcium x zinc x phosphorus interactions. J. Plant Nutr. 12:387-405.

Bazegskii, E.P., T.K. Egorova, and L.I. Zamyatina. 1976. Effect of liming on the effectiveness of phosphorus fertilizers. Agrokhimiya 7:36-44. (Abstract only)

Bolan, N.C., D.C. Adriano, and D. Curtin. 2003. Soil acidification and liming interactions with nutrient and heavy metal transformation and bioavailability. Advances. Agron. 78:215-272.

Brady, N.C., and R.R. Weil. 1999. In Nature and Properties of Soils. Prentice-Hall, Englewood Cliffs, NJ, USA.

Brown, J.R., and J.R. Cisco. 1984. An improved Woodruff buffer for estimation of lime requirements. Soil Sci. Soc. Am. J. 48:587-92.

Buol, S.W., R.J. Southard, R.C. Graham, and P.A. McDaniel. 2003. Soil Genesis and Classification. $5^{\text {th }}$ ed. Blackwell Publishing, Ames, Iowa, USA.

Burman, U., B.K. Garg, and S. Kathju. 2004. Interactive effects of thiourea and phosphorus on clusterbean under water stress. Biol. Plant. 48:61-65.

Cao, J. 2000. Effect of different fertilizer combinations on water supply-demand status of winter wheat. J. Applied Ecology. 11:713-7. 
Chen, J.H., and S.A. Barber. 1990. Effect of liming and adding phosphate on predicted phosphorus uptake by maize on acid soils of three soil orders. Soil Science. 150:844-850.

Chen, J.H., and S.S. Lin. 1994. Comparison of seven methods for measuring the lime requirements of strongly acid soils. Zhongguo Nongye Huaxue Huizhi 32:61-74. (Abstract only).

Clark, D.A, and S.L. Harris. 1996. Effects of high rates of nitrogen fertilizer on white clover growth, morphology, and nitrogen fixation activity in grazed dairy pasture in northern New Zealand. NZ J. Agr. Res. 39:149-158.

Cockayne, A.H. 1956. Grasslands of New Zealand. p. 585-595. In Proceedings of the VII International Grassland Congress, Palmerston North, New Zealand.

Collins, D.P., and P.B. O' Donovan. 1969. An evaluation of white clover in swards for calf feeding. p. 285-291. In Lowe, J. (ed.) Proceedings of a Symposium on White Clover Research, Queens University, Belfast, 22-25 September, 1969.

Corine, C. de Groot., L.F.M. Marcelis, R. Boogaard, W.M. Kaiser, and H. Lambers. 2003. Interaction of nitrogen and phosphorus nutrition in determining growth. Plant and Soil 248:257-268.

Curtin, O., H.P.W. Rostad, and P.M. Huang. 1984. Soil acidity in relation to soil properties and lime requirement. Canad. J. Soil. Sci. 64:545-554.

Curtin, D., and G.W. Smillie. 1983. Effects of liming on soil chemical characteristics and grass growth in laboratory and long-term field-amended soils. 1. Soil chemistry. Plant and Soil 95:15-22. 
Curtin, C., and G.W. Smillie. 1984. Influence of liming on soluble and labile P in fertilized soil. Commun. Soil Sci. Plant Anal. 15:177-188.

Dahlgren, R., S. Shoji, and M .Nanzyo. 1993. Mineralogical characteristics of volcanic ash soils. p.101-144. In S. Shoji, M. Nanzyo and R. Dahlgren (ed.) Volcanic Ash Soil- Genesis, Properties, and Utilization. Developments in Soil Science. Elsevier, Amsterdam, Holland.

Daniel, G., M. Palkovics, S. Nemeth, and I. Talajtani. 1989. Determination of the lime requirement of various soils by the buffer method. Agrokem. Talajtan. 38:71-3. (Abstract only)

David, C.N. 2004. Kenaf forage and quality under varying water availability. Agron. J. 96:204-213.

DeWalle, D.R., G.C. Ribblett, J.D. Helvey, and J. Kochenderfer. 1985. Laboratory investigation of leachate chemistry from six Appalachian forest floor types subjected to simulated acid rain. J. Envir. Quality. 14:234-240.

Dunham, R.J., and P.H. Nye. 1976. The influence of water content on the uptake of ions by roots III. Phosphate, potassium, calcium and magnesium uptake and concentration gradients in soil. J. Applied Ecology. 13:967-984.

Eckert, D.J. 1987. Soil test interpretations: Basic cation saturation ratios and sufficiency levels. In J.R. Brown (ed.) Soil Testing, Sampling, Correlation, Calibration, and Interpretation. Special Publication No. 21. Soil Science Society of America. Madison, WI, USA. 
Ernani, P.R., J.A.L. Nascimento, M.L. Campos, and R.J. Camillo. 2000. Influence of phosphorus and liming combination on corn yield. Rev. Bras. Cienc. Solo. 24:537-544. (Abstract only)

Evangelou, V.P. 1995. Pyrite Oxidation and its Control. CRC/Lewis Press, Boca Raton, FL.

Evans, L.S., K.F. Lewin, and F.A. Vella. 1980. Effect of nutrient medium pH on symbiotic nitrogen fixation by Rhizobium leguminosarum and Pisum sativum. Plant and Soil 56:71-80.

Fiez, T.E., B.C. Miller, and W.L. Pan. 1994. Winter wheat yield and grain protein across varied landscape positions. Agron. J. 86:1026-1032.

Fox, R.H .1980. Comparison of several lime requirement methods for agricultural soils in Pennsylvania. Commun. Soil Sci. Plant Anal.11:57-69.

Fox, R.L., S.K. De Datta, and J.M. Wang. 1964. Phosphorus and aluminium uptake by plants from latosols in relation to liming. Trans. $8^{\text {th }}$ Int. Congr. Soil Sci. IV. 595603.

Goulding, K.W.T, and B. Annis. 1998. Lime, liming and the management of soil acidity. p.36. Proc. Fertilizer Soc. No. 410, The International Fertilizer Society York, England.

Grierson, P.F., N.B. Comerford, and N.B. Jokela. 1999. Phosphorus mineralization and microbial biomass in a Florida spodosol: Effects of water potential, temperature and fertilizer application. Biol. Fertil. Soils 28:244-252. 
Gutierrez-Boem, F.H., and G.W. Thomas. 1998. Phosphorus nutrition affects wheat response to water deficits. Agron. J. 90:166-171.

Halder, B.R., and L.N. Mandal. 1985. Lime requirement of acid soils in relation to $\mathrm{pH}$, extractability, extractable acidity and exchangeable aluminum content of the soil. J. Indian. Soc. Soil Sci. 33:528-35.

Haynes, R.J. 1982. Effects of liming on phosphate availability in acid soils. Plant and Soil. 68:289-308.

Haynes, R.J., and T.E. Ludecke. 1981. Effect of lime and phosphorus applications on concentrations of available nutrients and on $\mathrm{P}, \mathrm{Al}$ and $\mathrm{Mn}$ uptake by two pasture legumes in acid soil. Plant and Soil 62:117-128.

Helyar, K.R., and A.J. Anderson. 1970. Responses of five pasture species to phosphate, lime, and nitrogen on an infertile acid soil with a high phosphate sorption capacity. Aust. J. Agr. 21:677-692.

Helyar, K.R., and A.J. Anderson. 1971. Effect of lime on the growth of five species, aluminum toxicity and phosphorus availability. Aust. J. Agr. 22:707-721.

Hopmans, P., D.W. Flinn, and P.W.Farrel. 1980. Nitrogen mineralization in a sandy soil under native eucalypt forest and exotic pine plantations in relation to moisture content. Commun. Soil Sci. Plant Anal.11:71-79.

Igue, K., H. Gargantini, and M. Alcover. 1970. Effect of liming and phosphate manuring on wheat cultivated in a soil of low pH and fertility. Bragantia 29:59- 66. (Abstract only). 
Jenny, H., and R. Overstreet. 1939. Cation interchange between plant roots and soil colloids. Soil Sci. 47:257 - 272 .

Kamprath, E.J. 1970. Exchangeable aluminum as a criterion for liming leached mineral soils. Soil Sci. Soc. Am. Proc. 24:252-254.

Kasturikrishna, S., and P.S. Ahlawat. 1999. Growth and yield response of pea (Pisum sativum L.) to moisture stress, phosphorus, sulphur and zinc fertilizers. Indian J. Agron. 44:558-596.

Leidi, E.O., and D.N. Rodriguez-Navarro. 2000. Nitrogen and phosphorus availability limit $\mathrm{N}_{2}$ fixation in bean. New Phytol. 147:337-346.

Lemare, P.H., and L.A. Leon. 1989. The effects of lime on adsorption and desorption of phosphate in five Colombian soils. Eur. J. Soil Sci. 40:59-69.

Longhurst, J.W.S. 1991. Acid Deposition: Origin, Impacts and Abatement Strategies. Springer-Verlag. New York, USA.

Lyngstad, I. 1992. Effect of liming on mineralization of soil nitrogen as measured by plant uptake and nitrogen released during incubation. Plant and Soil 144:247-253.

Machacha, S. 2004. Comparison of laboratory pH buffer methods for predicting lime requirement for acidic soils of eastern Botswana. Commun. Soil Sci. Plant Anal. 35:2675-2687.

Mackay, A.D., and S.A. Barber. 1985. Soil moisture effects on root growth and phosphorus uptake by corn. Agron. J. 77:519-523.

Magdoff, F.R., and R.J. Bartlett. 1985. Soil pH buffering revisited. Soil Sci. Soc. Am. J. 49:145-148. 
McBride, M.B. 1994. Environmental Chemistry of Soils. Oxford University Press. New York, USA.

McLean, E.O. 1973. Testing soils for $\mathrm{pH}$ and lime requirement. p.77-95. In L.M. Walsh and J.D. Beaton (ed.) Soil Testing and Plant Analysis. Soil Science Society of America. Madison, WI, USA.

McLean, E.O. 1978. Principles underlying the practice of determining lime requirements of acid soils. Commun. Soil Sci. Plant Anal. 9:699-715.

McLean, E.O., D.J. Eckert, G.Y. Reddy, and J.F. Trierweiller. 1978. An improved SMP soil lime requirement method incorporating double buffer and quick test features. Soil Sci. Soc. Am. J. 4:311-316.

McLean, E.O., and J.R. Brown.1984. Crop response to lime in the Midwestern United States. p.269-303. In F.Adam (ed.) Soil Acidity and Liming, Agronomy 12, American society of Agronomy, Madison, WI, USA.

Mederski, M.J., and J.W. Wilson. 1960. Relation of soil moisture to ion absorption by corn plants. Soil Sci. Soc. Am. Proc. 24:149-152.

Mehlich, A. 1976. New buffer $\mathrm{pH}$ method for rapid estimation of exchangeable acidity and lime requirements of soils. Commun. Soil Sci. Plant Anal. 7:253-263.

Mengel, K., and E.A. Kirkby. 1987. Principles of Plant Nutrition. International Potash Institute, Worblaufen, Bern

Miller, R.D., and D.D. Johnson. 1964. Effect of soil moisture tension on carbon dioxide evolution, nitrification, and nitrogen mineralization. Soil Sci. Soc. Am. Proc. 28:644- 647. 
Murrmann, R.P., and M. Peech. 1969. Effect of pH on labile and soluble phosphates in soils. Soil Sci. Soc. Am. Proc. 33:205-210.

Naidu, R., R.W. Tillman., J.K. Syers., and J.H. Kirkman. 1987. Effect of liming on phosphate extracted by two soil-testing procedures. Fert. Res. 14:143-152.

Naidu, R., J.K. Syers, R.W. Tillman, and J.H. Kirkman. 1990. Effect of liming and added phosphate on charge characteristics of acid soils. J. Soil Sci. 41:157-164.

NASS. 2005. National Agricultural Statistics Service. http://www.nass.usda.gov.

NRCS. 2004. National Resources Conservation Service. http://soils.usda.gov/.

Nyborg, M., and P.B. Hoyt. 1978. Effects of soil acidity and mineralization of soil nitrogen. Canad. J. Soil Sci. 58:331-338.

Olsen, S.R., W.D. Kemper, and J.C. Van Schaik. 1965. Self-diffusion coefficients of phosphorus in soil measured by transient and steady-state methods. Soil Sci. Soc. Am. Proc. 29:154-158.

Overman, A.R., and R.V. Schotz III. 2003. Model comparison for three forage grasses at the same location. Commun. Soil Sci. Plant Anal. 34: 735-745

Owusu-Bennoah, E., D.K. Acquaye, and T. Mahamah. 1995. Comparative study of selected lime requirement methods for some acid Ghanaian soils. Commun. Soil Sci. Plant Anal. 26:937-50.

Parfitt, R.L. 1980. Chemical properties of variable charge soils. p.167-194. In B.K.G. Theng (ed.) Soils with Variable Charge. New Zealand Society of Soil Science, Lower Hutt, New Zealand. 
Parks, G.A., and P.L. DeBruyun. 1962. The zero point of charge of oxides. J. Phys. Chem. 66:967-972.

Patiram, K.L., and R.N. Prasad. 1991. Evaluation of lime requirement methods to achieve the soil pH 6.0 and 5.5 for the acidic soils of Sikkim. Trop. Agri. (Trinidad). 68:284-8. (Abstract only)

Peoples, M.B., D.M. Lilley, V.F. Burnett, A.M. Ridley, and D.L. Garden. 1995. Effects of surface application of lime and superphosphate to acid soils on growth and $\mathrm{N}_{2}$ fixation by subterranean clover in mixed pasture swards. Soil Biol. and Biochem. 27:663-671.

Pier, J.W., and T.A. Doerge. 1995. Nitrogen and water interactions in trickle-irrigated watermelon. Soil Sci. Soc. Am. J. 59:145-150.

Rangely, A., and P. Newbould. 1985. Growth responses to lime and fertilizers and critical concentrations in herbage of white clover in Scottish hill soils. Grass Forage Sci. 40:265-277.

Reichman, G.A., D.L. Grunes, and F.G. Viets. 1966. Effect of soil moisture on ammonification and nitrification in two northern plains soils. Soil Sci. Am. Proc. $30: 363-366$

Ritchey, K.D., and J.D. Snuffer. 2002. Limestone, gypsum and magnesium oxide influence the restoration of an abandoned Appalachian pasture. Agron. J. 94:830839. 
Robinson, J.B.D. 1957. The critical relationship between soil moisture content in the region of the wilting point and mineralization of native soil nitrogen. J. Agr. Sci. 49:100-105.

Runge, A., and M.W. Rode. 1991. Effects of soil acidity on plant associations. p. 183202. In B. Ulrich and M.E. Sumner (ed.) Soil Acidity. Springer-Verlag, New York, USA.

Russel, E.W. 1973. Soil Conditions and Plant Growth. Longman, London.

Saeed, I.A.M., and A.H. El-Nadi. 1998. Forage sorghum yield and water use efficiency under variable irrigation. Irrig. Sci. 18:67-71.

Sanchez, P.A., and G. Uehara. 1980. Management considerations for acid soils with high phosphorus fixation capacity. p. 471-514. In The role of phosphorus in agriculture. American Society of Agronomy, Madison, WI, USA.

Sato, S., and N.B. Comerford. 2005. Influence of soil pH on inorganic phosphorus sorption and desorption in a humid Brazilian ultisol. R.Bras. Ci. Solo. 29:686694.

Shoemaker, H.E., E.O. Mclean, and P.F.Pratt. 1961. Buffer methods for determining lime requirement of soils with appreciable amounts of extractable aluminum. Soil Soc. Am. Proc. 25:274-277.

Singh, D.K., and P.W.G. Sale. 2000. Growth and potential conductivity of white clover roots in dry soil with increasing P supply and defoliation frequency. Agron. J. 92:868-874. 
Slangen, J.H.G., and P. Kerkhoff. 1984. Nitrification inhibitors in agriculture and horticulture. Fert. Res. 5:1-76.

Smyth, T.J., and P.A. Sanchez. 1980. Effects of lime, silicate, and phosphorus applications to an oxisol on phosphorus sorption and iron retention. Soil Sci. Am. J. 44:500-505.

Tilman, D., M.E. Dodd, J. Silvertown, P.R. Poulton, A.E. Johnston, and M.J. Crawley. 1994. The Park Grass Experiment: Insights from the most long-term ecological study. p. 287-303. In R.A. Leigh and A.E. Johnston (ed.) Long-term Experiments in Agricultural and Ecological Sciences. CAB International, Wallingford.

Ulrich, B. 1994. Nutrient and acid-base budget of central European forest ecosystems. p. 1-50. In D L Godbold and A Hüttermann (ed.) Effects of Acid Rain on Forest Processes. Wiley Liss, New York.

Van Raij, B., and J.A. Quaggio. 1990. Extractable phosphorus availability indices as affected by liming. Commun. Soil. Sci. Plant Anal. 21:13-16.

Webber, M.O., P.B. Hoyt, N. Nyborg, and D. Corneau. 1977. A comparison of lime requirement methods for acid Canadian soils. Canad. J. Soil Sci. 57:361- 370.

White, R.W., and A.W. Taylor. 1977. Effect of pH on phosphate adsorption and isotopic exchange in acid soils at low and high additions of soluble phosphate. J.Soil Sci. 28:48-61.

Wilkinson, S.R., and G.W. Langdale. 1974. Fertility needs of the warm-season grasses. p.119-145. In Forage Fertilization. ASA, CSSA, and SSSA, Madison, WI, USA. 
Winston, M.L., P.F. Martin, and G.R. Smith. 1976. Lime and nitrogen influence on timothy yield and composition. Agron. J. 68:881-885.

Wong, C.C., and P.K. Eng. 1983. Small sward comparison of Stylosanthes and Desmodiam species grown in association with Guineagrass. MARDI Res. Bulletin 11:146-165.

Wood, M., J.E. Cooper, and A.J. Holding. 1984. Soil acidity factors and nodulation of Trifolium repens. Plant and Soil 78:367-379.

Woodruff, C.A. 1948. Testing soils for lime requirement by means of a buffer solution and an electrode. Soil Sci. 66:53:63.

Yuan, T.L. 1974. A double buffer method for the determination of lime requirement of acid soils. Soil Sci. Soc. Am. Proc. 38:437-441.

Zaman, M., H.J. Di., K.C. Cameron, and C.M. Frampton.1999.Gross nitrogen mineralization and nitrification rates and their relationships to enzyme activities and the soil microbial biomass in soils treated with dairy shed effluent and ammonium fertilizer at different water potentials. Biol. Fertil. Soils. 29:178-186.

Zhang, X.N., and A.Z. Zhao. 1997. Surface Charge. p.7-63. In T.R. Yu (ed.) Chemistry of Variable Charge Soils. Oxford University Press, New York, USA. 


\section{CHAPTER II}

\section{Grouping Soils by Taxonomic Order to Improve Lime Recommendations}

\subsection{ABSTRACT}

The success of a liming program is dependent upon the accuracy of the lime recommendation, which in turn depends on the quality of the underlying correlations and calibrations. Due to the expense, large-scale field calibration experiments are rarely conducted. The relatively low economic returns from pastures make it even more unlikely that a calibration experiment will be conducted, especially in West Virginia. Therefore any improvements in lime recommendations have to be made from lime correlations. Moreover, it is unlikely that a single lime correlation can accurately identify appropriate lime rates for all soils. Hence, the objectives of this study were to improve the accuracy of lime requirement using quick tests by accounting for soil order and to develop lime correlations for acidic pasture soils of West Virginia. Twenty five surface soil samples $(0-7.5 \mathrm{~cm})$ from the three major soil orders in the state (Alfisols, Inceptisols, Ultisols) were collected, most in cooperation with state soil scientists. Standard procedures for the determination of lime requirements by the Mehlich single Buffer, Adams-Evans Buffer and Shoemaker-McLean-Pratt Single Buffer methods were used. Statistically significant improvements in lime recommendations for target $\mathrm{pH} 6.5$ and 5.5 were achieved by accounting for soil order. Mehlich single buffer recommendations were better for Alfisols and Ultisols than for Entisols to achieve $\mathrm{pH}$ 6.5. Lime correlations were developed for all three chemical buffers by multiple 
regression where the independent variables were target $\mathrm{pH}$ and soil-buffer $\mathrm{pH}$. The Adam -Evans buffer predicted lime rates better for target $\mathrm{pH} 5.5$.

\subsection{INTRODUCTION}

The dominant soil orders for grasslands in West Virginia are Alfisols, Ultisols and Inceptisols. These soils tend to be acidic due to high precipitation and undulating topography. As a result of these factors, removal rate of base cations exceeds the rate of their liberation from non-exchangeable forms (DeWalle et al., 1985) resulting in soils dominated by variable charge minerals (Ritchey and Snuffer, 2002). Although lime is an inexpensive soil amendment, because economic returns to pasture are relatively low and lime applications can be difficult on the steep soils of the region, it is important that lime application accurately reflect to correct soil acidity.

Pasture soil samples for lime requirement determination are typically collected from the upper most portion of the A-horizon, typically less than $7.5 \mathrm{~cm}$. The properties used to distinguish between soil orders occur in subsurface horizons (e.g. base saturation at $125 \mathrm{~cm}$ below the top of argillic horizon to distinguish Alfisols from Ultisols), and so soil order would not be expected to influence epipedon lime requirement (Buol et al., 2003). However, in West Virginia, Aflisols are found over basic parent material and Ultisols over acid (felsic) crystalline rock and acidic sediments. Therefore, we are hypothesizing that accounting for soil order may improve lime recommendation correlations.

Various quick tests to estimate lime requirement based on the $\mathrm{pH}$ change of a buffer solution have been proposed. The choice of a buffer method depends on the 
physico-chemical properties of the soils to be tested and so tend to be common to a region of the country. Single-buffer methods were found to be as accurate as the more complicated double buffer methods to determine lime requirements after appropriate calibration (Tran and VanLierop, 1981). The most common chemical buffers used are Shoemaker, McLean, and Pratt single buffer (SMPB), Adams-Evans buffer (AEB), and Mehlich single buffer (MB). The SMPB method was designed to determine lime requirements for soils with high amounts of extractable aluminium and high buffer capacity (Shoemaker et al., 1961). The AEB was developed for soils (Ultisols) with low cation exchange capacity (Adams and Evans, 1962). Both SMPB (McLean et al., 1978) and AEB (Fox, 1980) were observed to underestimate LR of low buffer capacity soils and to overestimate the LR in soils with intermediate to high buffer capacity. The Mehlich buffer was designed to predict the amount of lime needed to neutralize extractable acidity (Tran and VanLierop, 1982). Average lime doses determined by the Mehlich buffer method were 59\% of lime predictions by incubations (Mehlich, 1976). West Virginia is the only state in the northeast region (NEC-67, 1995) and one of only two states in the Appalachian region (Sims, 1996) to use the Mehlich buffer method for lime requirement determinations (North Carolina is the other state).

Comparative studies of different methods for determining lime requirement have been carried out all over the world to determine the most appropriate buffer method. Nevertheless, disagreements still exist about the most accurate assessment of the lime requirement for a specific soil-plant system. Soil test lime correlations are strictly valid only for the soils used in making the determination. There are approximately 177 soil series mapped in West Virginia belonging to six orders (59 Alfisols, 50 Ultisols, 41 
Inceptisols, 19 Entisols, six Mollisols and two Spodosols) in four Major Land Resource Areas (MLRAs). Given this range of soils, a single correlation is unlikely to identify the appropriate lime rate for each soil. Possibly, lime recommendations by quick tests can be improved by developing correlations with reference methods such as lime incubations and direct $\mathrm{Ca}(\mathrm{OH})_{2}$ titrations.

\subsection{OBJECTIVES}

1. To test the suitability of Shoemaker-McLean-Pratt buffer (SMPB) and Adams-Evans buffer (AEB) for making lime recommendations in West Virginia

2. Test the hypothesis that accounting for soil order will improve lime recommendations, and

3. Determine lime correlations for the Adams-Evans, Shoemaker-McLeanPratt and Mehlich buffer methods.

\subsection{MATERIALS AND METHODS}

Samples from 25 soil series were collected in West Virginia, most in cooperation with State soil scientists. Samples were collected from the upper $7.5 \mathrm{~cm}$ of soil, air dried, sieved to pass a $2 \mathrm{~mm}$ sieve and stored in plastic containers until use. When necessary, soils were incubated with $\mathrm{Al}_{2}\left(\mathrm{SO}_{4}\right)_{3}$ to reduce initial $\mathrm{pH}$ to a common starting point of approximately 5.0. Many of these samples, collected as part of ongoing soil survey work in the state, were point samples from control pedons.

Standard methods were used to determine the chemical and physical properties known to influence lime requirement of each soil sample. Texture was determined by the 
pipette method (Gee and Bauder, 1986); organic matter content by dry combustion using a LECO CNS 2000 (Nelson and Sommers, 1996); secondary nutrients (Ca, Mg, K and P) by Mehlich I extraction (NEC-67), micronutrients by DTPA extraction (NEC-67); exchangeable $\mathrm{Al}$ and exchangeable acidity by $1 \mathrm{M} \mathrm{KCl}$ extraction (Sims, 1996); cation exchange capacity (Chapman, 1965), and non-crystalline oxides by ammonium oxalate extraction in the dark (Jackson et al., 1986). All elemental concentrations were determined by ICP-AES (Perkin Elmer P400, Norwalk, CT).

The 'true' value of the lime requirement was assumed to be equal to that determined by $\mathrm{Ca}(\mathrm{OH})_{2}$ titration (Dun, 1943). This approach has been used in many other lime requirement determination studies (e.g. Follet and Follet, 1980; McConnell et al., 1990). Soil buffer $\mathrm{pH}$ was determined by the Mehlich single Buffer (MB), Adams-Evans Buffer (AEB) and Shoemaker-McLean-Pratt Single Buffer (SMPB) methods (Sims, 1996). All determinations were performed in triplicate. 'Estimated' lime requirements were obtained using measured buffer $\mathrm{pH}$ and the appropriate calibration table (Van Lierop, 1990; Adams and Evans, 1962).

Lime correlations were determined by multiple regression where the independent variables were target $\mathrm{pH}$ and soil-buffer $\mathrm{pH}$. Estimated $\mathrm{LR}$ values were compared to true LR values using Dunnett's t-test $(\infty=0.05)$, before and after grouping by order. 


\subsection{RESULTS AND DISCUSSION}

As collected, the mean $\mathrm{pH}$ of soil samples varied from 4.78 to 5.04, clay content from 22.7 to $25 \%$, organic matter content from 4.68 to $5.53 \%$, and CEC $\left(\mathrm{cmol}_{\mathrm{c}} \mathrm{kg}^{-1}\right.$ ) from 13.33 to 15.6 (Table 2.5.1).

Table 2.5.1. Mean, range and standard deviation of soil $\mathrm{pH}$, silt, clay and organic matter contents and cation exchange capacity (CEC) grouped by soil order.

\begin{tabular}{lcccc}
\hline & & & Soil Order & \\
Parameter & Statistic & Alfisol & Ultisol & Inceptisol \\
\hline $\mathrm{pH}$ & mean & 4.92 & 4.78 & 5.04 \\
& range & $4.8-5.17$ & $4.44-5.08$ & $4.8-5.17$ \\
Silt $(\%)$ & st. dev & 0.17 & 0.30 & 0.13 \\
& mean & 39.14 & 45.41 & 42.9 \\
& range & $9.36-61.16$ & $21.74-55.63$ & $30.4-51.3$ \\
Clay $(\%)$ & st. dev & 17.82 & 13.6 & 7.09 \\
& mean & 23.57 & 22.7 & 25 \\
& range & $17.9-31.9$ & $18.1-27.3$ & $17-38.2$ \\
OM $(\%)$ & st. dev & 3.82 & 3.49 & 6.85 \\
& mean & 5.53 & 4.68 & 5.01 \\
& range & $3.8-9.2$ & $3.5-7.9$ & $2.9-7.5$ \\
CEC $\left(\mathrm{cmol}_{\mathrm{c}} \mathrm{kg}\right)$ & st. dev & 1.72 & 1.84 & 1.67 \\
& mean & 14.7 & 13.3 & 15.6 \\
& range & $8.2-24.7$ & $8.5-16.1$ & $8.3-22.8$ \\
& st. dev & 5.16 & 3.47 & 6.43 \\
\hline
\end{tabular}

\subsubsection{Determination of lime requirement with chemical buffers}

The 'true' LR increased as target $\mathrm{pH}$ increased, as expected (Table. 2.5.2). The rate of increase was approximately $1.2 \mathrm{Mg} \mathrm{ha}^{-1}$ per unit increase in target $\mathrm{pH}$. SMPB 'estimated' LRs were consistently higher than either AEB or MB for all target $\mathrm{pH}$ levels. The mean over-prediction was greater for SMPB and AEB than for MB. 
Table 2.5.2. Mean LR values for different target $\mathrm{pH}$ levels

\begin{tabular}{llccc}
\hline \multirow{3}{*}{ Order } & & \multicolumn{3}{c}{ Lime Requirement } \\
\cline { 3 - 5 } Alfisols & Method & 5.5 & 6.0 & 6.5 \\
\cline { 3 - 5 } & & --- Target $\mathrm{pH}$ \\
& SMPB & 6.11 & 7.83 & 9.24 \\
& AEB & 2.76 & 5.23 & 8.15 \\
& MB & 3.23 & 5.73 & 6.05 \\
\multirow{3}{*}{ Ultisols } & Titration & 1.53 & 2.89 & 4.25 \\
& SMPB & 5.60 & 7.51 & 8.68 \\
& AEB & 3.04 & 5.51 & 8.28 \\
& MB & 3.51 & 6.15 & 6.52 \\
& Titration & 1.54 & 2.54 & 3.71 \\
& SMPB & 4.74 & 6.46 & 7.41 \\
& AEB & 1.73 & 4.20 & 7.4 \\
& MB & 3.8 & 5.53 & 5.82 \\
& Titration & 0.97 & 2.02 & 3.10 \\
\hline
\end{tabular}

Except for AEB and a target $\mathrm{pH}$ of 5.5, all buffer methods over-estimated LR at all target $\mathrm{pH}$ (Table. 2.5.3) compared to true LR values by direct calcium hydroxide titration method. The over-prediction for SMPB was consistently larger than for the other two methods. Shoemaker et al. (1961) found that predicted lime values using SMPB were significantly higher than the amount required by $\mathrm{CaCO}_{3}$ incubation to attain $\mathrm{pH} 6.5$. 
Table 2.5.3. Comparison of buffer methods with direct calcium hydroxide titration method for different target $\mathrm{pH}$ levels before grouping by soil order

\begin{tabular}{llcccc}
\hline Target $\mathrm{pH}$ & Method & $\begin{array}{c}\text { Mean } \\
\text { Difference* }\end{array}$ & $\begin{array}{c}\text { Mean } \\
\text { square } \\
\text { error }\end{array}$ & $\begin{array}{c}\text { Dunnett's } \\
\text { t value }\end{array}$ & $\begin{array}{c}\text { Dunnett's t } \\
\text { critical value }\end{array}$ \\
\hline 6.5 & SMPB & 5.20 & & $7.74^{*}$ & 2.38 \\
& MB & 1.98 & 1.60 & $2.94^{*}$ & \\
& AEB & 3.61 & & $5.37^{*}$ & \\
6.0 & SMPB & 4.76 & & $7.94^{*}$ & \\
& MB & 3.19 & 4.48 & $5.32^{*}$ & 2.38 \\
& AEB & 2.42 & & $4.04^{*}$ & \\
& & & & $7.79 *$ & \\
& SMPB & 4.25 & & $3.42^{*}$ & 2.38 \\
& MB & 1.87 & 3.71 & 2.10 & \\
\hline
\end{tabular}

* Mean difference between Buffer method predicted LR and $\mathrm{Ca}(\mathrm{OH})_{2}$ titration estimated LR

The 'estimated' LR by chemical buffers were plotted against the true LR by direct $\mathrm{Ca}(\mathrm{OH})_{2}$ titration to target $\mathrm{pH} 6.5$ (Fig. 2.5.1). The SMPB lime requirement for target $\mathrm{pH}$ 6.5 ranged from 1.2 to $18.8 \mathrm{Mg} \mathrm{ha}^{-1}$. SMPB exhibited greater change in buffer $\mathrm{pH}$, ranging from 4.92 to 7.07 . The buffering capacity of the SMPB solution seemed to be lowest. Vanlierop (1983) also oberved that SMPB has a greater sensitivity to change in $\mathrm{pH}$ for a given soil lime requirement. The higher sensitivity of SMPB resulted in a significant correlation $\left(\mathrm{R}^{2}=0.89\right)$ with actual values determined by direct $\mathrm{Ca}(\mathrm{OH})_{2}$ titration. The mean difference between AEB and true LR values significantly different (3.63 $\mathrm{Mg} \mathrm{ha}^{-1}$ ) for target $\mathrm{pH} 6.5$ (Table 2.5.3). AEB overestimated the lime requirement despite a significant correlation $\left(\mathrm{R}^{2}=0.81\right)$ with titration method (Fig. 2.5.1). The AEB solution showed relatively high resistance to change in buffer $\mathrm{pH}(6.96-7.68)$ for a given soil. The Mehlich single buffer under-predicted lime requirements for soils with low buffer capacity and over-predicted it for highly buffered soils. Lime requirements were 
significantly correlated $\left(R^{2}=0.88\right)$ with 1:1 line of true values (a plot of $L R$ values determined by direct calcium hydroxide titration method). The mean of estimated LR values of Mehlich buffer was significantly higher $\left(1.98 \mathrm{Mg} \mathrm{ha}^{-1}\right)$ than values of direct $\mathrm{Ca}(\mathrm{OH})_{2}$ titration at target $\mathrm{pH} 6.5$. The change in buffer $\mathrm{pH}$ of Mehlich buffer with soils ranged from 5.30 to 6.56 which indicated a relatively better sensitivity in predicting lime requirements than AEB. In this study, few lime values of highly buffered soils had enough influence on the regression line of Mehlich single buffer to deviate significantly from 1:1 line of true LR values. 


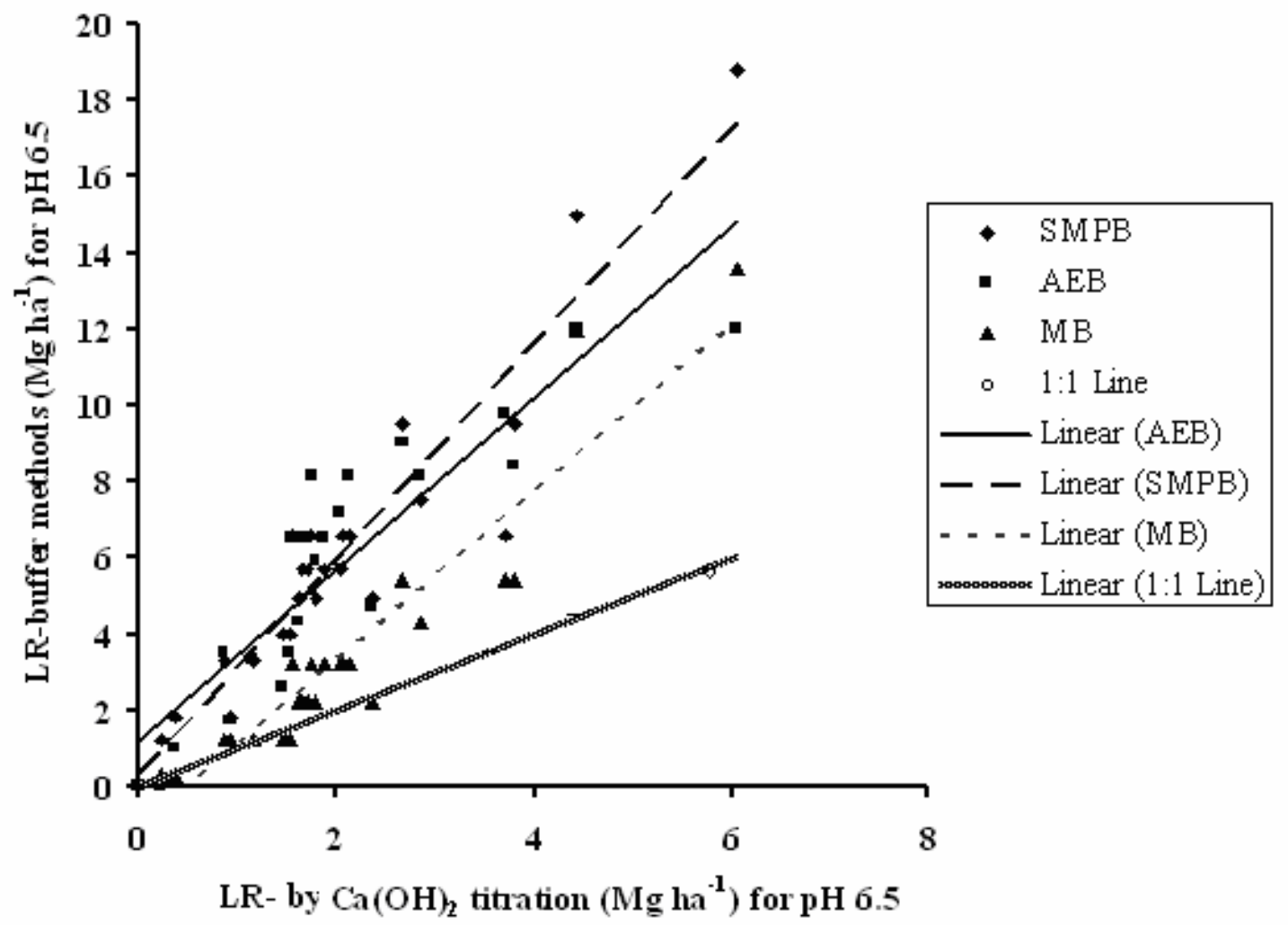

Figure 2.5.1. Lime requirement of 25 pasture soils as measured by three buffer methods vs $\mathrm{Ca}(\mathrm{OH})_{2}$ titration.

\subsubsection{Effect soil order on chemical buffer lime requirement predictions}

The SMPB method predictions did not improve after grouping by soil order at any target $\mathrm{pH}$. For a target $\mathrm{pH}$ of 5.5, grouping improved predictions for Alfisols and Ultisols with $\mathrm{AEB}$ and $\mathrm{MB}$ (Table 2.5.4). For a target $\mathrm{pH}$ 6.0, grouping improved predictions for Ultisols with AEB and MB. For target $\mathrm{pH}$ 6.5, grouping improved predictions for Alfisols and Ultisols with MB (Figures 2.5.2a-2.5.2c). 
Table 2.5.4. Soil grouping effect on lime requirement by quick tests for different target $\mathrm{pH}$ levels.

\begin{tabular}{|c|c|c|c|c|c|c|}
\hline Order & $\begin{array}{l}\text { Target } \\
\mathrm{pH}\end{array}$ & Method & $\begin{array}{c}\text { Mean } \\
\text { Difference }\end{array}$ & $\begin{array}{c}\text { Mean } \\
\text { square } \\
\text { error }\end{array}$ & $\begin{array}{l}\text { Dunnett's } \\
\text { t value }\end{array}$ & $\begin{array}{c}\text { Dunnett's t } \\
\text { critical } \\
\text { value }\end{array}$ \\
\hline \multirow[t]{9}{*}{ Alfisols } & \multirow[t]{3}{*}{5.5} & SMPB & 4.50 & & $5.07 *$ & \multirow{3}{*}{2.42} \\
\hline & & AEB & 1.16 & \multirow[t]{2}{*}{5.12} & 1.30 & \\
\hline & & MB & 1.63 & & 1.83 & \\
\hline & \multirow[t]{3}{*}{6.0} & SMPB & 5.03 & \multirow{3}{*}{6.11} & $5.18^{*}$ & \multirow{3}{*}{2.42} \\
\hline & & AEB & 2.44 & & $2.51 *$ & \\
\hline & & MB & 2.94 & & $3.03 *$ & \\
\hline & \multirow[t]{3}{*}{6.5} & SMPB & 4.62 & \multirow{3}{*}{6.86} & $4.49^{*}$ & \multirow{3}{*}{2.42} \\
\hline & & AEB & 2.80 & & $2.72 *$ & \\
\hline & & MB & 1.14 & & 1.10 & \\
\hline \multirow[t]{9}{*}{ Inceptisols } & \multirow[t]{3}{*}{5.5} & SMPB & 3.81 & \multirow{3}{*}{0.99} & $7.16^{*}$ & \multirow{3}{*}{2.50} \\
\hline & & AEB & 0.79 & & 1.48 & \\
\hline & & MB & 2.15 & & 4.04* & \\
\hline & \multirow[t]{3}{*}{6.0} & SMPB & 4.17 & \multirow{3}{*}{1.39} & $6.61^{*}$ & \multirow{3}{*}{2.50} \\
\hline & & AEB & 2.22 & & $3.52 *$ & \\
\hline & & MB & 3.55 & & $5.63 *$ & \\
\hline & \multirow[t]{3}{*}{6.5} & SMPB & 5.28 & \multirow{3}{*}{1.33} & $8.56^{*}$ & \multirow{3}{*}{2.50} \\
\hline & & AEB & 3.78 & & $6.13 *$ & \\
\hline & & MB & 2.94 & & $4.76^{*}$ & \\
\hline \multirow[t]{9}{*}{ Ultisols } & \multirow[t]{3}{*}{5.5} & SMPB & 4.05 & \multirow{3}{*}{4.14} & $3.14^{*}$ & \multirow{3}{*}{2.59} \\
\hline & & AEB & 1.49 & & 1.15 & \\
\hline & & MB & 1.97 & & 1.53 & \\
\hline & \multirow[t]{3}{*}{6.0} & SMPB & 4.97 & \multirow{3}{*}{5.39} & $3.38^{*}$ & \multirow{3}{*}{2.59} \\
\hline & & AEB & 2.97 & & 2.02 & \\
\hline & & MB & 3.60 & & 2.45 & \\
\hline & \multirow[t]{3}{*}{6.5} & SMPB & 5.43 & \multirow{3}{*}{5.84} & $3.55^{*}$ & \multirow{3}{*}{2.59} \\
\hline & & AEB & 4.38 & & $2.86^{*}$ & \\
\hline & & MB & 2.92 & & 1.91 & \\
\hline
\end{tabular}




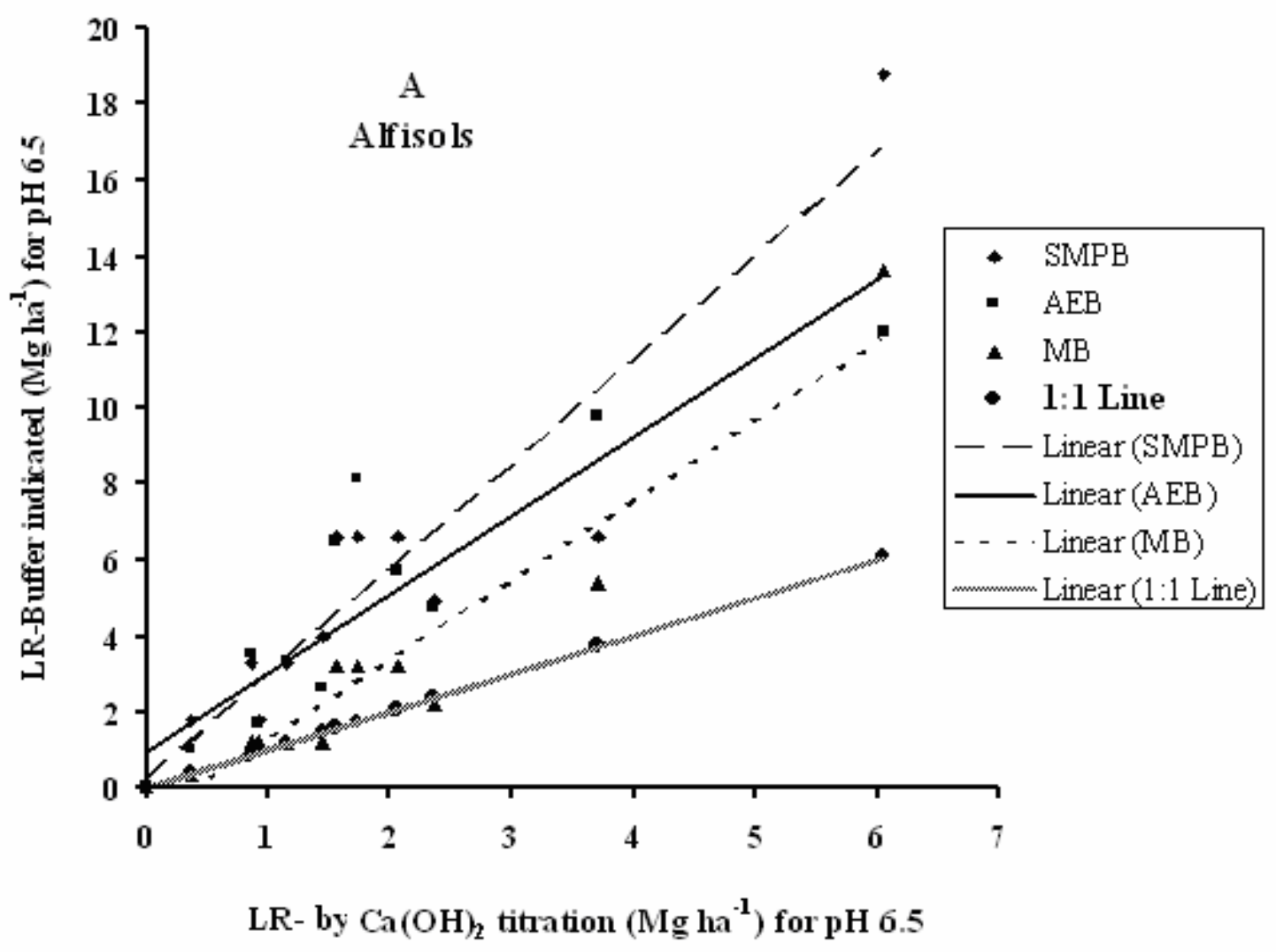

Figure 2.5.2a. Lime requirement of Alfisols as measured by three buffer methods vs. $\mathrm{Ca}(\mathrm{OH})_{2}$ titration. 


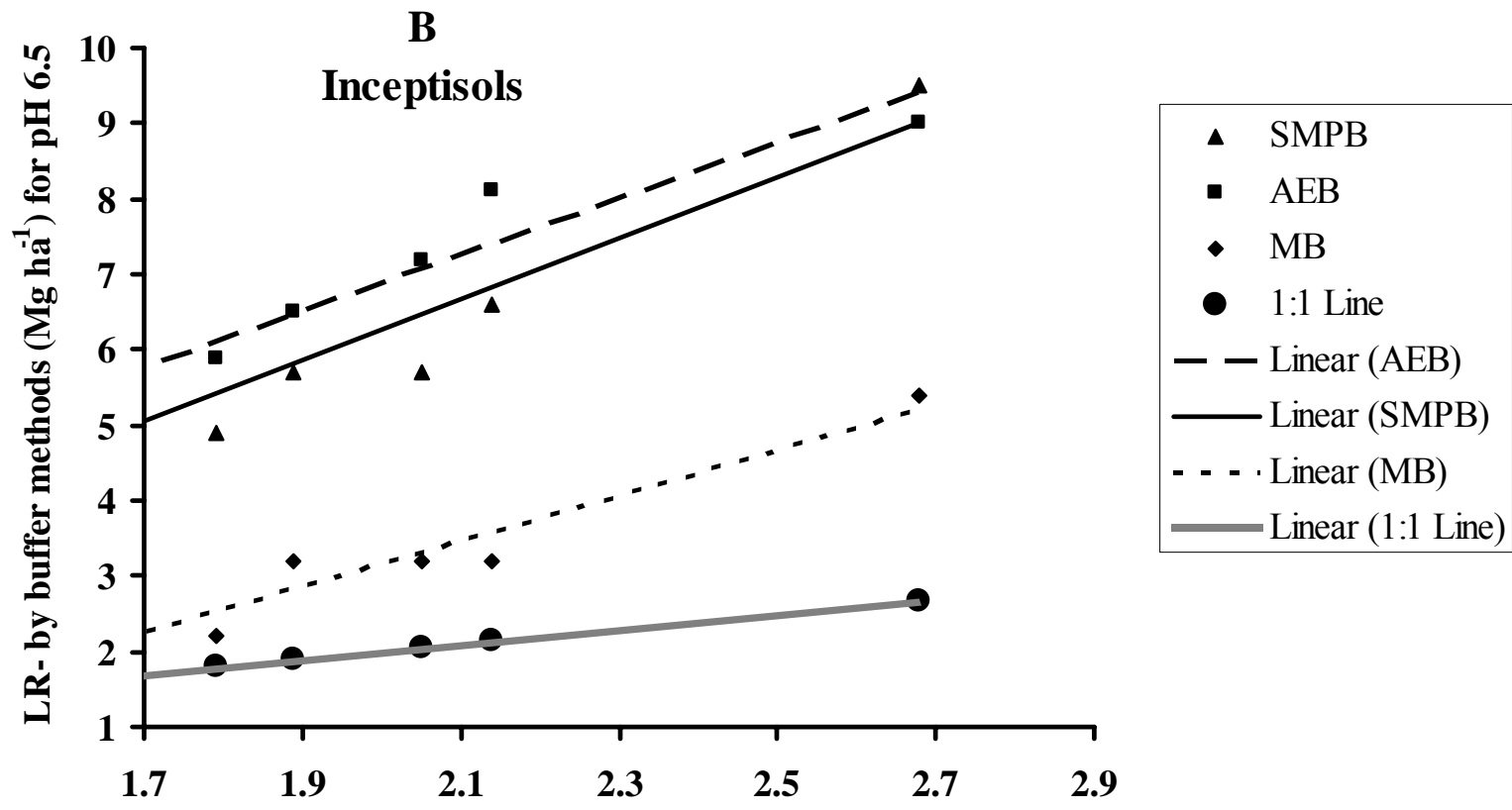

LR-by Ca(OH) $)_{2}$ titration $\left(\mathrm{Mg} \mathrm{ha}^{-1}\right)$ for pH 6.5

Figure 2.5.2b. Lime requirement of Inceptisols as measured by three buffer methods vs. $\mathrm{Ca}(\mathrm{OH})_{2}$ titration. 


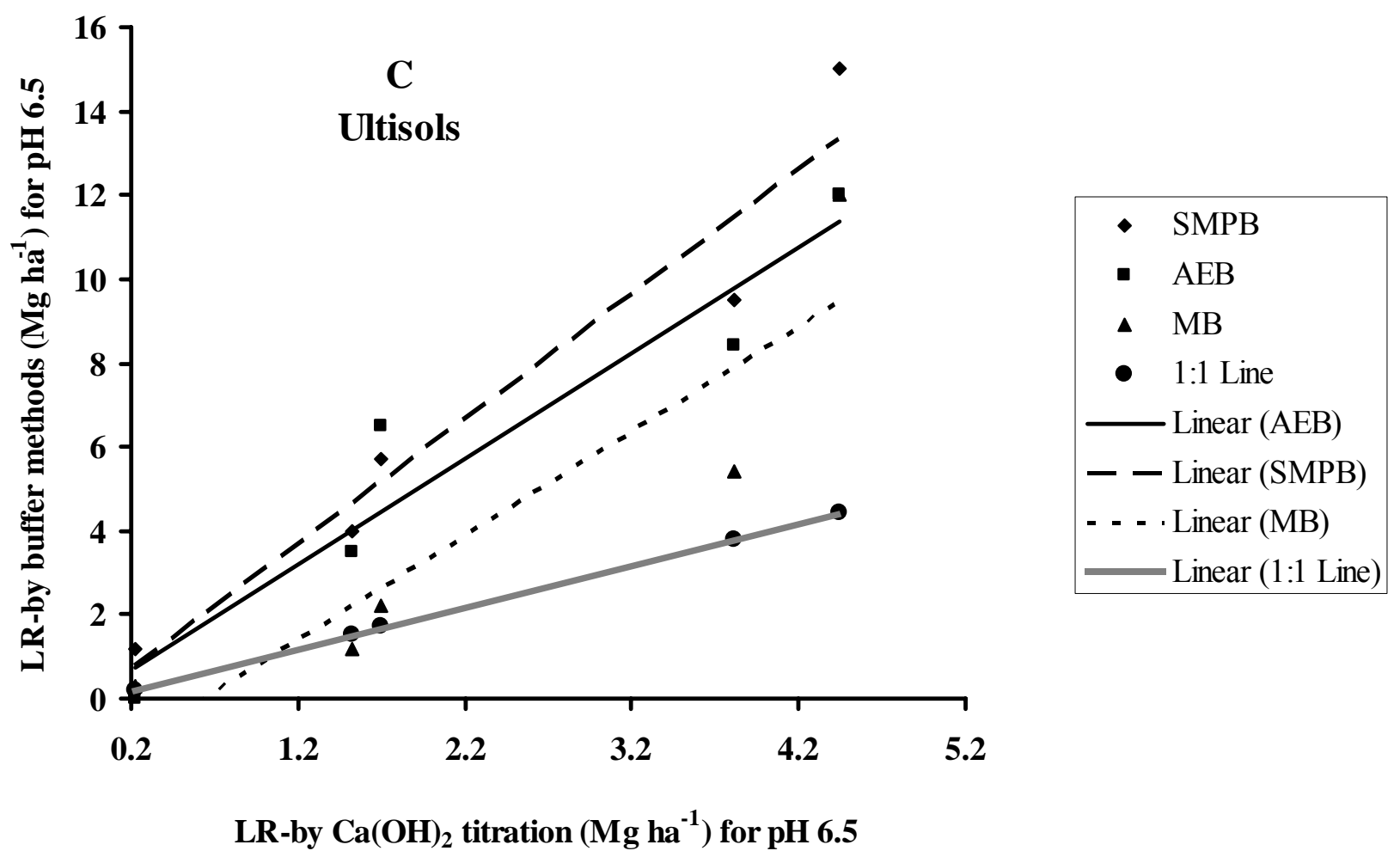

Figure 2.5.2c. Lime requirement of Ultisols as measured by three buffer methods vs. $\mathrm{Ca}(\mathrm{OH})_{2}$ titration.

\subsubsection{Improved lime recommendation correlations}

There are two reasons why the buffer method LR predictions may differ from the true $\mathrm{LR}$ as determined by $\mathrm{Ca}(\mathrm{OH})_{2}$ titration. First, the titration results may not represent the results obtained by $\mathrm{CaCO}_{3}$ incubation. Second, the underlying lime correlation equation may be in error. Because $\mathrm{Ca}(\mathrm{OH})_{2}$ titration has been shown to accurately predict $\mathrm{CaCO}_{3}$ incubation results (Alabi, 1986), and accounting for soil order significantly improved predictions for Alfisols and Ultisols for AEB and MB, we assumed that the 
error was with the lime correlation. The new correlation equations, some of which were not linear are given in Tables 2.5.5 - 2.5.7. Additional data will be needed to test the validity of these new correlation equations.

Table 2.5.5. Regression equations to predict lime requirements for target $\mathrm{pH} 5.5$

\begin{tabular}{llll}
\hline Buffer & Type & Order & Equations for LR $\left(\mathrm{Mg} \mathrm{ha}^{-1}\right)$ to target pH 5.5 \\
\hline MB & & & \\
& Linear & Alfisols & $\mathrm{LR}=15.0-2.28 * \mathrm{BpH}$ \\
& Quadratic & Inceptisols & $\mathrm{LR}=10.96-1.70 * \mathrm{BpH}+4.80^{*}(\mathrm{BpH}-5.94)^{2}$ \\
& & Ultisols & $\mathrm{LR}=23.15-3.62 * \mathrm{BpH}-5.84 *(\mathrm{BpH}-5.86)^{2}$ \\
AEB & & & \\
& Quadratic & Alfisols & $\mathrm{LR}=10.96-1.31 * \mathrm{BpH}+0.67 *(\mathrm{BpH}-7.18)^{2}$ \\
& & Inceptisol & $\mathrm{LR}=4.21-0.46 * \mathrm{BpH}+6.81 *(\mathrm{BpH}-7.25)^{2}$ \\
& & Ultisols & $\mathrm{LR}=22.79-2.94 * \mathrm{BpH}-3.29 *(\mathrm{BpH}-7.18)^{2}$ \\
SMPB & & Alfisols & $\mathrm{LR}=6.89-0.91 * \mathrm{BpH}+0.50 *(\mathrm{BpH}-5.85)^{2}$ \\
& Quadratic & Inceptisols & $\mathrm{LR}=5.73-0.80 * \mathrm{BpH}+3.62 *(\mathrm{BpH}-6.0)^{2}$ \\
& & Ultisols & $\mathrm{LR}=14.03-2.10 * \mathrm{BpH}-1.87 *(\mathrm{BpH}-5.84)^{2}$ \\
\hline
\end{tabular}

Table 2.5.6. Regression equations to predict lime requirements for target $\mathrm{pH} 6.0$

\begin{tabular}{|c|c|c|c|}
\hline Buffer & Type & Order & Equations for $\mathrm{LR}\left(\mathrm{Mg} \mathrm{ha}^{-1}\right)$ to target $\mathrm{pH} 6.0$ \\
\hline MB & Quadratic & $\begin{array}{l}\text { Alfisols } \\
\text { Inceptisols } \\
\text { Ultisols }\end{array}$ & $\begin{array}{l}\mathrm{LR}=37.06-5.77 * \mathrm{BpH}-4.12 *(\mathrm{BpH}-5.90)^{2} \\
\mathrm{LR}=32.90-5.20 * \mathrm{BpH}-12.55 *(\mathrm{BpH}-5.91)^{2} \\
\mathrm{LR}=26.64-4.04 * \mathrm{BpH}-6.42 *(\mathrm{BpH}-5.86)^{2}\end{array}$ \\
\hline AEB & $\begin{array}{l}\text { Linear } \\
\text { Quadratic }\end{array}$ & $\begin{array}{l}\text { Alfisols } \\
\text { Inceptisol } \\
\text { Ultisols }\end{array}$ & $\begin{array}{l}\mathrm{LR}=22.91-2.80 * \mathrm{BpH} \\
\mathrm{LR}=5.20-0.51 * \mathrm{BpH}+17.28 *(\mathrm{BpH}-7.25)^{2} \\
\mathrm{LR}=24.09-2.98 * \mathrm{BpH}-3.25 *(\mathrm{BpH}-7.18)^{2}\end{array}$ \\
\hline & $\begin{array}{l}\text { Linear } \\
\text { Quadratic }\end{array}$ & $\begin{array}{l}\text { Alfisols } \\
\text { Inceptisols } \\
\text { Ultisols }\end{array}$ & $\begin{array}{l}\mathrm{LR}=17.09-2.44 * \mathrm{BpH} \\
\mathrm{LR}=51.19-8.1 * \mathrm{BpH}-20.06 *(\mathrm{BpH}-6.02)^{2} \\
\mathrm{LR}=16.00-2.27 * \mathrm{BpH}-1.84 *(\mathrm{BpH}-5.84)^{2}\end{array}$ \\
\hline
\end{tabular}


Table 2.5.7. Regression equations to predict lime requirements for target $\mathrm{pH} 6.5$

\begin{tabular}{llll}
\hline Buffer & Type & Order & Equations for LR $\left(\mathrm{Mg} \mathrm{ha}^{-1}\right)$ to target pH 6.5 \\
\hline MB & & & \\
& Quadratic & Alfisols & $\mathrm{LR}=52.45-8.02 * \mathrm{BpH}-4.28^{*}(\mathrm{BpH}-5.90)^{2}$ \\
& & $\begin{array}{l}\text { Inceptisols } \\
\text { Ultisols }\end{array}$ & $\mathrm{LR}=19.82-2.87 * \mathrm{BpH}+6.28^{*}(\mathrm{BpH}-5.91)^{2}$ \\
AEB & & & \\
& Linear & Alfisols & $\mathrm{LR}=34.98-4.18 * \mathrm{BpH}$ \\
& Quadratic & Inceptisol & $\mathrm{LR}=4.84-0.32 * \mathrm{BpH}+13.75^{*}(\mathrm{BpH}-7.25)^{2}$ \\
& Linear & Ultisols & $\mathrm{LR}=26.17-3.14 * \mathrm{BpH}$ \\
SMPB & & & \\
& Linear & Alfisols & $\mathrm{LR}=25.43-3.50 * \mathrm{BpH}$ \\
& Quadratic & $\begin{array}{l}\text { Inceptisols } \\
\text { Ultisols }\end{array}$ & $\mathrm{LR}=13.84-1.83 * \mathrm{BpH}+3.25^{*}(\mathrm{BpH}-6.01)^{2}$ \\
& & UR $=18.38-2.50 * \mathrm{BpH}-1.41^{*}(\mathrm{BpH}-5.84)^{2}$ \\
\hline
\end{tabular}

In conclusion, in this study it was hypothesized that the accuracy of lime requirement could be improved by accounting for soil order. However, an improvement in accuracy was only seen in case of Mehlich and Adams-Evans buffer predictions and new lime correlation equations were developed. There appears to be an opportunity to improve lime predictions by accounting for soil order. However, these findings should be confirmed by extensive testing with larger number of samples. 


\subsection{REFERENCES}

Adams, F, and C.E. Evans. 1962. A rapid method for measuring lime requirement of Red-Yellow Podzolic soils. Soil Sci. Soc. Am. Proc. 26:355-357.

Alabi, K.E., R.C. Sorensen, D. Knudsen, and O.H. Rehm. 1986. Comparison of several lime requirement methods on coarse textured soils of Northeastern Nebraska. Soil Sci. Soc. Am. J. 50:937-941.

Buol, S.W., R.J. Southard, R.C. Graham, and P.A. McDaniel. 2003. Soil Genesis and Classification. $5^{\text {th }}$ ed. Blackwell Publishing, Ames, Iowa, USA.

Chapman, H.D. 1965. Cation exchange capacity. p.891-900. In C.A. Black (ed.) Method of Soil Analysis, Part 2: Chemical and Microbiological Properties. Am. Soc. Agron., Madison, WI, USA.

DeWalle, D.R., G.C. Ribblett, J.D. Helvey, and J. Kochenderfer. 1985. Laboratory investigation of leachate chemistry from six Appalachian forest floor types subjected to simulated acid rain. J. Environ. Qual. 14:234-240.

Dun, L.E. 1943. Lime requirement determination of soils by means of titration curves. Soil Sci. 56:341-351.

Follett, R.H., and R.F. Follett. 1980. Strengths and weaknesses of soil testing in determining lime requirements for soils. p. 40-51. In Proc. of the Natl. Conf. on Agric. Limestone 16-18 Oct. 1980. TVA National Fertilizer Development Center, Muscle Shoals, AL, USA.

Fox, R.H. 1980. Comparison of several lime requirement methods for agricultural soils in Pennsylvania. Commun. Soil Sci. Plant Anal. 11:57-69. 
Gee, G.W., and J.W. Bauder. 1986. Particle size analysis. In A. Klute (ed.) Methods of Soil Analysis. Part 1. Physical and Mineralogical Methods. 2nd Ed. American Society of Agronomy, Madison, WI, USA.

Jackson, M.L., C.H. Lim, and L.W. Zelazny. 1986. Oxides, hydroxides and aluminosilicates. In A. Klute (ed.) Methods of Soil Analysis. Part 1. Physical and Minerological Methods. $2^{\text {nd }}$ Ed. American Society of Agronomy, Madison, WI, USA.

McConnell, J.S., J.T. Gilmour, R.E. Baser, and B.S. Frizzell. 1990. Lime requirement of acid soils of Arkansas. Arkansas Experiment Station Special Report 150. Arkansas Agricultural Experiment Station, Fayetteville, AR, USA.

McLean, E.O., D.J. Eckert, G.Y. Reddy, and J.F. Trierweiller. 1978. An improved SMP soil lime requirement method incorporating double buffer and quick test features. Soil Sci. Soc. Am. J. 4:311-316.

McLean, E.O., H.E. Shoemaker, and W.R. Hourigan. 1960. Some effects of aluminum on lime requirement tests of soils. p. $142-151$. In Transaction International Congress of Soil Science, Madison, WI, USA.

Mehlich, A. 1976. New buffer $\mathrm{pH}$ method for rapid estimation of exchangeable acidity and lime requirement of soils. Commun. Soil Sci. Plant Anal. 7:253-263.

NEC-67. Northeast Coordinating Committee on Soil Testing. 1995. Recommended Soil Testing Procedures for the Northeastern United States. Northeastern Regional Publication No.493. Agricultural Experiment Station, University of Delaware. Nelson, D.W., and L.E. Sommers. 1996. Total carbon, organic carbon, and organic matter. In D.L. Sparks (ed.) Methods of Soils Analysis. Part 3. Chemical 
Methods. SSSA Book Series No. 5. American Society of Agronomy. Madison, WI, USA.

Ritchey, K.D., and J.D. Snuffer. 2002. Limestone, gypsum and magnesium oxide influence the restoration of an abandoned Appalachian pasture. Agron. J. 94:830839.

Shoemaker, H.E., E.O. McLean, and P.F.Pratt. 1961. Buffer methods for determining lime requirement of soils with appreciable amounts of extractable aluminum. Soil. Soc. Am. Proc. 25:274-277.

Sims, J.T. 1996. Lime requirement. In D.L. Sparks (ed.) Methods of Soil Analysis. Chemical Methods. SSSA Book Series No.5. American Society of Agronomy. Madison, WI, USA.

Tran, T.S., and W. Van Lierop. 1981. Evaluation and improvement of buffer-pH lime requirement methods. Soil Sci. 131:178-188.

Tran, T.S., and W. VanLierop. 1982. Lime requirement determination for attaining $\mathrm{pH}$ 5.5 and 6.0 of coarse textured soils using buffer $\mathrm{pH}$ methods. Soil Sci. Soc.Am.J. $46: 1008-1014$.

Van Lierop, W. 1983. Lime requirement determination of acid organic soils using bufferpH methods. Canad. J. Soil Sci. 63:411-423.

Van Lierop, W. 1990. Soil pH and lime requirement. p.73 -126. In R.L. Westerman (ed.) Soil Testing and Plant Analysis. $2^{\text {nd }}$ ed. SSSA, Madison, WI, USA. 


\section{CHAPTER III}

\section{Available Water Effect On Optimum pH, Nitrogen and Phosphorus Requirements \\ I. Kentucky Bluegrass}

\subsection{ABSTRACT}

The productivity of grasslands depends on soil factors such as water potential, $\mathrm{pH}$, $\mathrm{N}$ and $\mathrm{P}$ levels. There is a need to understand the interactive effects of these factors on yields of grasslands. Response surface methodology was applied to optimize yield of bluegrass for an acidic pasture soil. The effects of two levels of water potential (WP) and five levels each of $\mathrm{pH}, \mathrm{N}$, and $\mathrm{P}$ fertilizer additions were evaluated to optimize bluegrass herbage mass. Water potential, $\mathrm{pH}$, and $\mathrm{N}$ were significant main effects, as were the interactions $\mathrm{WP} \times \mathrm{pH}, \mathrm{WP} \times \mathrm{N}$, and $\mathrm{pH} \times \mathrm{N}$. The yield response function was derived from these four factors. The order of importance for these model parameters was WP $>\mathrm{N}$ $>\mathrm{pH} \approx \mathrm{WP} \times \mathrm{pH}>\mathrm{WP} \times \mathrm{N}>\mathrm{N} \times \mathrm{N}>\mathrm{pH} \times \mathrm{N}$. The optimum levels of these four factors were predicted by the RSREG procedure. These results have implications for how to divide pastures into management zones for optimal bluegrass production.

\subsection{INTRODUCTION}

Remediation of soil acidity is crucial for improving pasture soil quality and increasing herbage accumulation. Application of liming materials and fertilizers are needed to stimulate plant growth by reducing acid related constraints and increasing the availability of Ca, N, P and Mo (Adams, 1984). Liming results in changes in soil 
chemical and physical properties which improve conditions for plant growth (Menzies et al., 1994).

Liming has been shown to reduce sodium acetate extractable $\mathrm{Al}$, Fe and $\mathrm{H}$ ions (Ryan and Smillie, 1975), while increasing the soil cation exchange capacity (Hockman et al., 1992) and crop yields (Holford and Crocker, 1994). Another important reason for liming is to increase phosphate availability (Sanchez and Uehara, 1980). However, liming soils can either increase or decrease extractable P (Mendoza et al., 1995). Application of fertilizers to lime amended soils is an important management practice to restore the balance among cations and anion concentrations in soil solution and so promote plant growth.

Crop growth will be improved by liming when sufficient levels of plant essential nutrients are available. Therefore, optimum plant growth requires well balanced nutrient applications in addition to liming. Nitrogen fertilization is the main agronomic practice influencing grassland productivity and quality (Wilkinson and Langdale, 1974), and has been studied for many years. Johnson et al. (2001) studied the effects of nitrogen fertilization on yield of three tropical grasses in a study where five rates of nitrogen $(0$, $39,78,118$, and $157 \mathrm{~kg} \mathrm{~N} \mathrm{ha}^{-1}$ ) were applied. The forage mass increased by $129 \%$ at 78 $\mathrm{kg} \mathrm{N} \mathrm{ha}{ }^{-1}$ compared with no $\mathrm{N}$ fertilization. Additional $\mathrm{N}$ did not cause a further increase in forage mass. A similar increase in dry matter yield due to $\mathrm{N}$ fertilization in warmseason grasses was observed (Harvey et al., 1996; Caraballo et al., 1997). Malhi et al. (2004) studied the effect of N, P and K levels on productivity of timothy (Phleum pretense $L$.). They found that application of $\mathrm{N}$ markedly increased dry matter yield but $\mathrm{P}$ 
and $\mathrm{K}$ had moderate effects. The supply of $\mathrm{N}$ and $\mathrm{P}$ in fertilizers has been proven to significantly influence dry matter yield of grasslands.

Liming and application of fertilizers also have an impact on uptake of nutrients by plants. The uptake of $\mathrm{P}, \mathrm{K}, \mathrm{Ca}, \mathrm{Mg}$, and $\mathrm{Na}$, utilization of $\mathrm{N}$ and $\mathrm{P}$, and nutrient ratios were all positively correlated with dry matter yield and crude fiber concentration of meadow fescue grown from 1965 to 1974 (Wermke,1975).

Pasture fertilization increases nutrient availability in soil, interacts with other elements present in the soil, and increases forage growth (Clark and Harris, 1996). Liming along with application of fertilizers enhanced the concentration of N, P, Ca, and $\mathrm{Mg}$ in the soil as well as doubled the uptake by meadow plants without any negative effect on their soil concentrations (Kasperczyk et al., 2005). Staputis (2000) observed that soil $\mathrm{pH}$, liming and fertilization affected the yield and nutrient accumulation in a spring barley-red clover-spring wheat rotation. He also found that the optimal $\mathrm{pH}$ for nutrient uptake by plants was 4.6-5.0 in loamy sand and 5.0 in light and medium loam soil, despite the higher $\mathrm{N}$ assimilated at $\mathrm{pH} 6.5$ in medium loam soil.

Uptake of nutrients by plants is influenced by other elements present in the soil (Clark and Harris, 1996). Mayfield et al. (2002) observed maximum uptake of N, Ca, K, and $\mathrm{P}$ by Nandina domestica grown in soil-less media in treatments that received lime compared to the un-limed controls. Fageria et al. (1995) found that increasing levels of applied $\mathrm{P}\left(0.50\right.$ and $\left.175 \mathrm{mg} \mathrm{kg}^{-1}\right)$ significantly increased nutrient uptake by upland rice (Oryza sativa L.), wheat (Triticum aestivum L.), common bean (Phaseolus vulgaris L.) and Corn (Zea mays L.) grown on an Oxisol. But, increasing levels of lime (0, 2, and $4 \mathrm{~g}$ $\mathrm{kg}^{-1}$ ) tended to decrease uptake of $\mathrm{P}, \mathrm{Zn}, \mathrm{K}, \mathrm{Cu}, \mathrm{Mn}$, and $\mathrm{Fe}$ and increased the uptake of 
$\mathrm{Ca}$ and $\mathrm{Mg}$ in all crops. Foloni et al. (2006) observed that the application of ammonium sulfate along with lime was most effective in the enhancement of $\mathrm{Ca}$ and $\mathrm{Mg}$ uptake by cotton plants grown for 60 days in PVC columns filled with a sandy loam Oxisol. It was concluded that nitrogen fertilization added anions that increased the solubility of basic cations in the soil due to the formation of ionic pairs.

In contrast, liming agents and rates did not enhance the degree of absorption of macronutrients by sugarcane under field conditions (Prado et al., 2002). Different rates of lime application had no influence on $\mathrm{K}$ uptake by rice and lettuce grown on acid sulfate soils (Ramesh and Chonkar, 2001). Liming decreased the uptake of $\mathrm{Mg}, \mathrm{Mn}$, and $\mathrm{Zn}$ by maize plants grown on two acid Ultisols. Maize grown in an Ultisol expressed severe $\mathrm{Mn}$ deficiency due to liming soil to neutralilty even though a moderate amount of Mn was applied (Juo and $\mathrm{Uzu}, 1977$ ). Increased application of $\mathrm{CaO}$ or $\mathrm{MgO}$ reduced the uptake of $\mathrm{N}$ and Fe in rice plants, but $\mathrm{K}$ uptake was unaffected (Houng et al., 1967). Application of $\mathrm{CaO}$ was observed to increase $\mathrm{Mg}$ uptake, whereas $\mathrm{Mg}$ application reduced $\mathrm{Ca}$ uptake. Moreover, application of $\mathrm{Mg}$ without $\mathrm{Ca}$ caused severe stunting in rice.

The important and often neglected factor affecting nutrient availability in the field is soil water content, which has a significant effect on nutrient release from applied fertilizers as well as on mineralization reactions (Koerselman et al., 1993). Fertilizer use efficiency is a function of available water (Fiez et al., 1994; Gutierrez-Boem and Thomas, 1998). Superphosphate requires minimal moisture to dissolve P from the granule (Lawton and Vomocil, 1954). For grasslands on undulating terrain, the variation in toposequence influences water potential which can play a critical role in solubilization 
and transport of minerals in the soil and thus should be considered while designing management practices for pastures.

Available literature on forage response to water potential and fertilization is fragmented and not always integrated into a continuum of information relating to optimization of forage production on acidic pasture soils. A greater research effort is needed to develop comprehensive input recommendations to modify these low production and low income systems. In order to transform these low productivity systems to higher producing pasture systems, we need a better understanding of the interactions between fertilizers, water potential and other elements present in the soil.

The objectives of this study were to quantify the effects of water potential (WP), soil $\mathrm{pH}, \mathrm{N}$ and $\mathrm{P}$ on Kentucky bluegrass yield and nutrient uptake.

\subsection{MATERIALS AND METHODS}

An acidic soil was collected near Morgantown, WV from the Culleoka Westmoreland map unit, air-dried, crushed and passed through a $2 \mathrm{~mm}$ sieve. Soil $\mathrm{pH}$ was determined by glass membrane electrode; texture by the pipette method (Sternberg and Creager, 1961); organic matter content by loss on ignition (Oliver et al., 2001); and CEC by the ammonium acetate method (Chapman, 1965). A lime response curve was determined by direct $\mathrm{Ca}(\mathrm{OH})_{2}$ titration (Alabi et al., 1986). The soil moisture characteristic curve was determined using a dew-point potentiometer (Decagon Model WP4-T) and gravimetry. All determinations were done in triplicate. 
To produce soils with different $\mathrm{pH}$ levels, sufficient $\mathrm{Ca}(\mathrm{OH})_{2}$ was added, based on the lime response curve, to separate sub-samples to establish a range of final soil $\mathrm{pH}$ from 4.5 to 6.5 in approximately 0.5 increments. Limed soils were incubated at field capacity for one week, or until equilibrium $\mathrm{pH}$ was reached. Soils were again air-dried and stored until use. Soil was placed in pots $(30.5 \mathrm{~cm} \times 30.5 \mathrm{~cm} \times 5 \mathrm{~cm})$ and four rates of nitrogen were established by incorporating nitrogen $\left(\mathrm{NH}_{4} \mathrm{NO}_{3}\right)$ or phosphorus (as $\mathrm{KH}_{2} \mathrm{PO}_{4}$ ). Nitrogen was added at $0,10,25,50$ and $100 \mathrm{mg} \mathrm{N} \mathrm{kg}^{-1}$ soil. Phosphorus was added at 0 , 10, 20, 40 and $80 \mathrm{mg} \mathrm{Pg}^{-1}$ soil. Two water potentials, near field capacity (pF 2.7) and just above the permanent wilting point ( $\mathrm{pF}$ 3.9), as determined from the soil-water characteristic curve, were imposed and maintained using a sensor-based irrigation system (NETAFIM Flori 1). Water content was measured regularly by potentiometer (Decagon Model WP4-T). To reduce the number of experimental units a centrally composite rotatable design (Myers and Montgomery, 1995) with three replications was used (Appendix (Table A5)). Pots were directly seeded with Kentucky bluegrass (Poa pratensis L.) at the rate of $4 \mathrm{gm} \mathrm{pot}^{-1}$. Every three weeks a sample of the soil solution before watering was drawn with a soil solution sampler (Rhizon SMS) and analyzed for $\mathrm{pH}$ (microelectrode) and $\mathrm{Ca}^{2+}, \mathrm{PO}_{4}{ }^{3-}, \mathrm{NH}_{4}{ }^{+}$and $\mathrm{NO}_{3}{ }^{-}$by ion chromatography (DX-300, Dionex Corp). At the end of the experiment (60 days after sowing) herbage accumulation was measured by clipping at ground level and drying the herbage at $105{ }^{\circ} \mathrm{C}$ for 48 hours. The nutrient concentration in plants was determined by analyzing the above ground portion. Herbage was digested with concentrated $\mathrm{HNO}_{3}$ using microwave (MARS 5, CEM) ) (Rechcigal and Payne 1990). The extracts from this wet digestion were used to 
determine nutrient concentrations by ICP-OES (Perkin Elmer P400, Norwalk, CT). Nutrient concentrations were expressed on a tissue dry mass basis.

Herbage accumulation data were analyzed using a response surface methodology and the PROC RSREG procedure with Ridge max option in SAS (ver 9.1, SAS Institute, Cary, NC, USA). Herbage accumulation was the response variable and water potential, $\mathrm{pH}, \mathrm{N}$, and $\mathrm{P}$ rates were added to construct model main effects. The linear, quadratic, and cross product terms of these factors were also determined. A step-wise regression procedure was used to determine the best model. Adjusted $\mathrm{R}^{2}$ and $\mathrm{Cp}$ statistics were used to select model parameters. The effect of factors as linear, quadratic, and interaction (cross product) coefficients on the response variable (herbage accumulation) was tested for adequacy and fitness by analysis of variance. Concentrations of nutrients in herbage were analyzed to study the effect of water potential, $\mathrm{pH}, \mathrm{N}$, and $\mathrm{P}$ levels.

\subsection{RESULTS AND DISCUSSION}

The soil texture was a silt clay loam ( $34.3 \%$ clay; $44.0 \%$ silt), with an initial $\mathrm{pH}$ of 4.8, organic matter content $-9.2 \%, \mathrm{Ca}-42.5 \mathrm{ppm}, \mathrm{Mg}-9.8 \mathrm{ppm}, \mathrm{K}-40.8 \mathrm{ppm}, \mathrm{P}-$ $4.06 \mathrm{ppm}$, and a CEC of $15.84 \mathrm{cmol}_{\mathrm{c}} \mathrm{kg}^{-1}$. The lime response curve was linear from $\mathrm{pH}$ 5.2 to 6.5 (Appendix (Fig. A1)). On average, water potential (pF) was 2.7 in the field capacity treatment and 3.91 in the near wilting point treatment which were gravimetrically equal to $16 \%$ and $30 \%$ respectively (Appendix (Fig. A2-A3)). 


\subsection{1. $\quad$ Yield model}

Analysis of variance showed that the model significantly predicted herbage accumulation (response variable) despite the presence of a significant lack-of-fit (Table 3.4.1). A residual plot indicated no pattern in the residuals (Fig. 3.4.1), but a large variability. The lack of fit term was not significant when mean values were used (Fig. 3.4.2). These results suggest that a factor affecting yield was not captured by the treatments selected.

Table 3.4.1. Analysis of variance for model of response surface function

\begin{tabular}{llrrrl}
\hline Source & df & Sum of Squares & Mean Square & F Ratio & Pr $>$ F \\
\hline Model & 13 & 121.5 & 9.34 & 92.29 & $<0.0001$ \\
Error & 82 & 8.30 & 0.10 & & \\
Lack Of Fit & 16 & 3.96 & 0.24 & 3.77 & $<0.0001$ \\
Pure Error & 66 & 4.33 & 0.06 & & \\
C. Total & 95 & 129.8 & & & \\
\hline
\end{tabular}

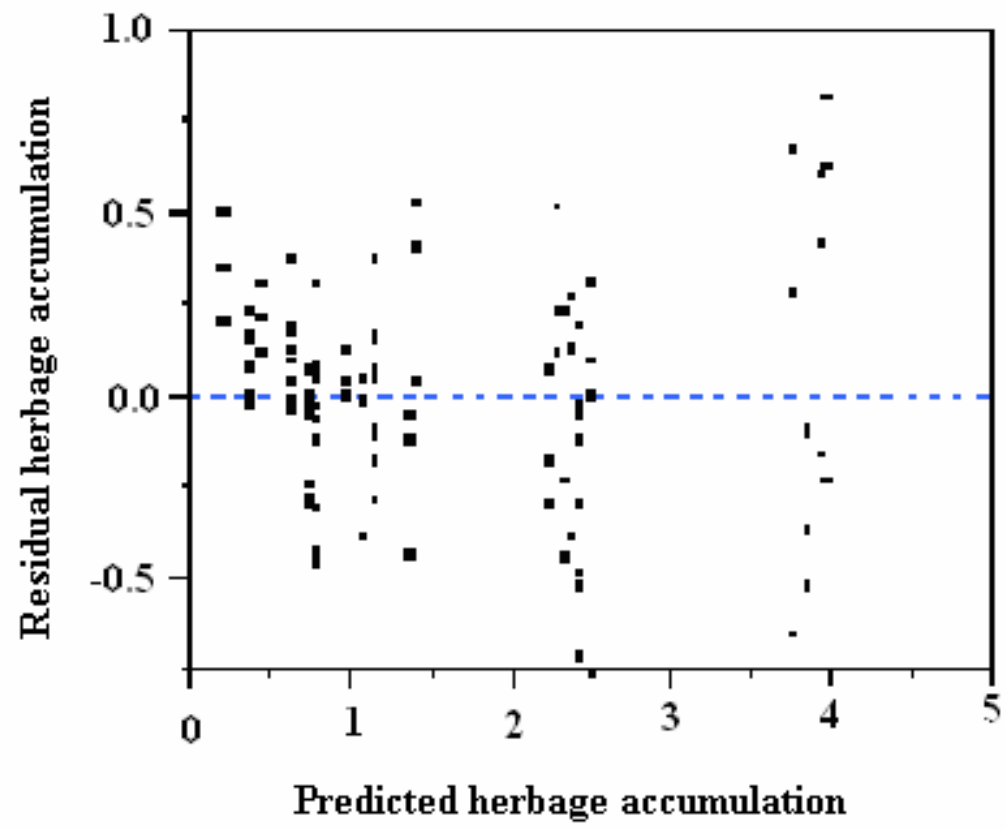

Figure. 3.4.1. Residuals plot for herbage accumulation 


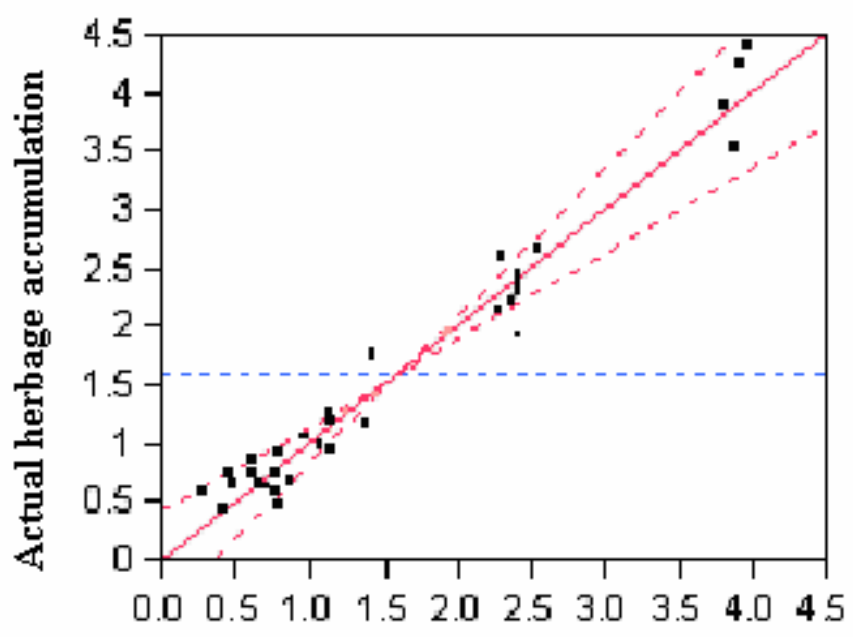

Predicted herbage accumulation

Figure 3.4.2. Actual vs. predicted herbage accumulation. Dashed lines indicate $95 \%$ confidence interval

Water potential, $\mathrm{pH}$ and $\mathrm{N}$ levels were the only main effects that influenced herbage accumulation $(\mathrm{p}<0.05)$ (Table 3.4.2). The cross product terms of water potential, $\mathrm{pH}$ and $\mathrm{N}$ as well as quadratic term of $\mathrm{N}$ were also significant. Phosphorus level was not significant as a main effect or as an interaction.

Water potential had the largest influence on bluegrass herbage accumulation, as indicated by sum of squares followed by $\mathrm{N}$ level (Table 3.4.2), The main effect of $\mathrm{pH}$ and the water potential by $\mathrm{pH}$ interaction were of similar importance, followed by the water potential by $\mathrm{N}$ interaction and the $\mathrm{N}$ quadratic effect. These terms were used to determine the response surface function,

$$
\begin{aligned}
& \mathrm{Y}=2.12-(1.5 * \mathrm{WP})+(0.7 * \mathrm{pH})+(0.02 * \mathrm{~N})- \\
& 1.09 *(\mathrm{WP}-3.305) *(\mathrm{pH}-5.5)-0.017 *(\mathrm{WP}-3.305) *(\mathrm{~N}-30.625)
\end{aligned}
$$




$$
+0.01 *(\mathrm{pH}-5.5) *(\mathrm{~N}-30.625)-0.00023 *(\mathrm{~N}-30.625) *(\mathrm{~N}-30.625)
$$

where $\mathrm{Y}$ is herbage accumulation $\left(\mathrm{Mg} \mathrm{ha}^{-1}\right), \mathrm{WP}$ is water potential $(\mathrm{pF}), \mathrm{pH}$ is in standard units, $\mathrm{N}$ is nitrogen rate $\left(\mathrm{mg} \mathrm{kg}^{-1}\right)$, and $\mathrm{P}$ is phosphorus rate $\left(\mathrm{mg} \mathrm{kg}^{-1}\right)$. Although the $\mathrm{pH}$ by $\mathrm{N}$ interaction was statistically significant, it was not included in the response surface model because it accounted for so little of the sum of squares (Table 3.4.2).

Table 3.4.2. Analysis of variance for the overall and interaction effects of the four factors on bluegrass yield

\begin{tabular}{llrrrr}
\hline Source & df & Estimates & $\begin{array}{r}\text { Sum of } \\
\text { squares }\end{array}$ & F-ratio & Pr $>$ F \\
\hline $\mathrm{WP}(\mathrm{pF})$ & 1 & -1.477792 & 76.737720 & 757.7211 & $<.0001$ \\
$\mathrm{~N}$ & 1 & 0.0229643 & 14.474719 & 142.9258 & $<.0001$ \\
$\mathrm{pH}$ & 1 & 0.6761241 & 10.009114 & 98.8317 & $<.0001$ \\
$\mathrm{P}$ & 1 & 0.0036056 & 0.209323 & 2.0669 & 0.1543 \\
$\mathrm{WP}{ }^{*} \mathrm{pH}$ & 1 & -1.093205 & 10.498455 & 103.6635 & $<.0001$ \\
$\mathrm{WP} * \mathrm{~N}$ & 1 & -0.017119 & 5.877817 & 58.0385 & $<.0001$ \\
$\mathrm{~N}^{*} \mathrm{~N}$ & 1 & -0.00023 & 2.702855 & 26.6884 & $<.0001$ \\
$\mathrm{pH} \mathrm{N}$ & 1 & 0.0111268 & 0.611855 & 6.0416 & 0.0161 \\
$\mathrm{P}^{*} \mathrm{P}$ & 1 & -0.000114 & 0.256907 & 2.5367 & 0.1151 \\
$\mathrm{pH} \mathrm{P}$ & 1 & -0.008014 & 0.182767 & 1.8047 & 0.1829 \\
$\mathrm{~N}^{*} \mathrm{P}$ & 1 & -0.000071 & 0.022681 & 0.2240 & 0.6373 \\
$\mathrm{pH} \mathrm{H}^{*} \mathrm{pH}$ & 1 & 0.0473971 & 0.016209 & 0.1601 & 0.6901 \\
$\mathrm{WP} \mathrm{P}$ & 1 & -0.000719 & 0.006345 & 0.0627 & 0.8030 \\
\hline
\end{tabular}

Based on parameter estimates, as the value of water potential increased (therefore drier) herbage accumulation was decreased (Table 3.4.2). The positive sign on parameter estimates of $\mathrm{N}$ and $\mathrm{pH}$ indicate that increasing soil $\mathrm{pH}$ and nitrogen fertilization increased herbage accumulation (Table 3.4.2)

The water potential by soil $\mathrm{pH}$ interaction showed that in addition to increasing herbage accumulation as $\mathrm{pF}$ decreased (increase in water potential), the rate of the 
increase per unit increase in soil $\mathrm{pH}$ increased as $\mathrm{pF}$ decreased (Fig. 3.4.3). Increasing soil $\mathrm{pH}$ did not increase herbage accumulation at the lowest water potential ( $\mathrm{pF} 3.90)$.

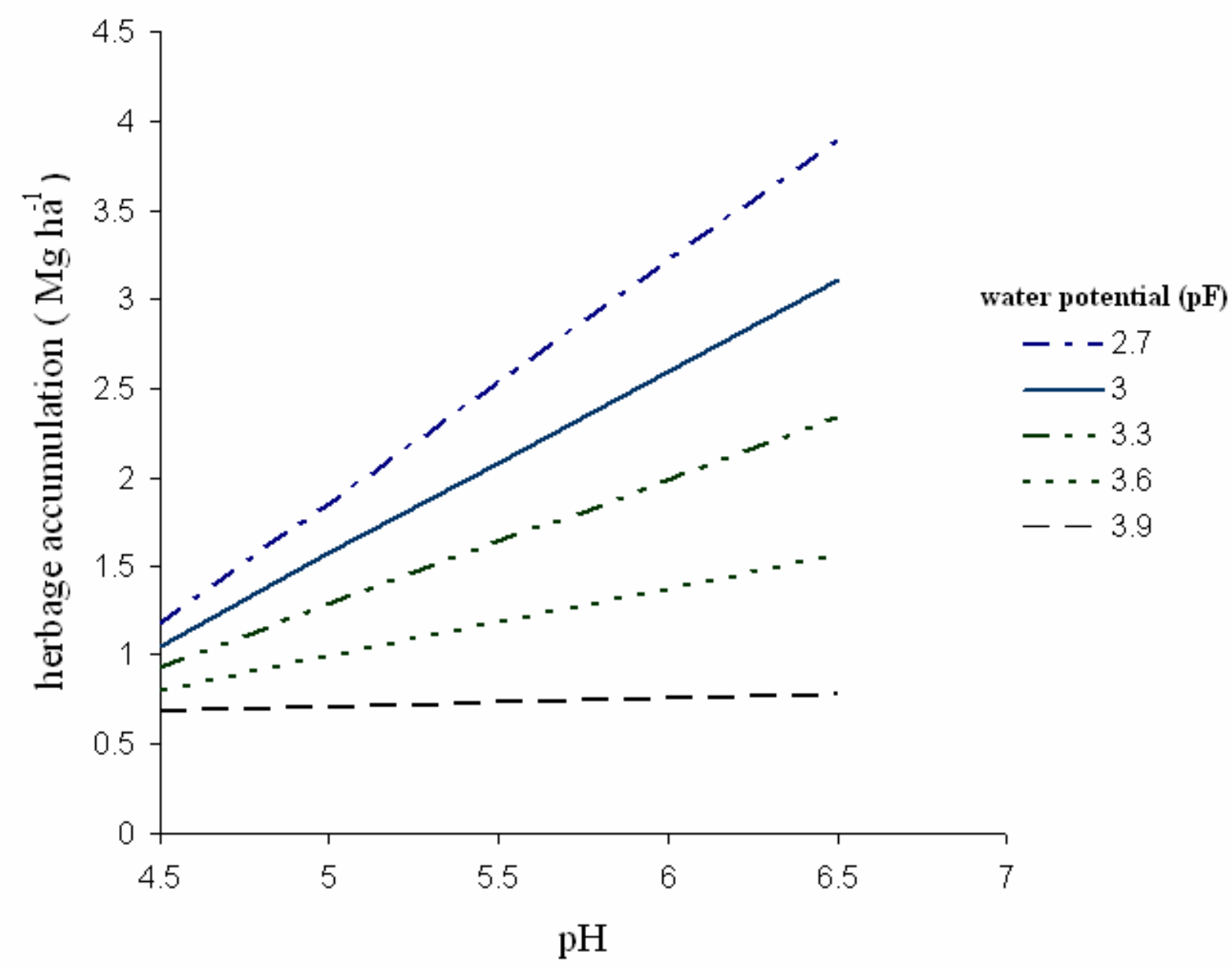

Fig. 3.4.3. Effect of water potential and $\mathrm{pH}$ level on Kentucky bluegrass herbage accumulation

Saeed and El- Nadi (1998) observed a response in dry matter yield of forage sorghum (Sorghum bicolor L.) to irrigation over two seasons. In their study, the dry matter yields were $16.3,11.8$, and $10.5 \mathrm{Mg} \mathrm{ha}^{-1}$ for frequent $\left(8 \mathrm{~mm} \mathrm{day}^{-1}\right.$ every 7 days), intermediate ( $8 \mathrm{~mm}$ day $^{-1}$ every 10 days $)$ and infrequent $\left(8 \mathrm{~mm} \mathrm{day}^{-1}\right.$ every 13 days $)$ 
irrigation regimes respectively. Paula et al. (1989) studied the effect of liming on yields of wheat. They observed maximum dry matter yields of $15.86,15.88$ and $12.53 \mathrm{~g} /$ pot for higher quantities of calcium to reach target $\mathrm{pH}$ 6.0. There have not been studies on the effects of both water potential and $\mathrm{pH}$ on dry matter yield as has been done in this study.

The yield response to added $\mathrm{N}$ increased as soil moisture increased (Figure 3.4.4). At the lowest water potential (high $\mathrm{pF}$ ), $\mathrm{N}$ additions had minimal effect on herbage accumulation and actually reduced yields at the higher $\mathrm{N}$ rates. The highest dry matter yields were observed at the highest water potential (low pF) with at least $100 \mathrm{mg} \mathrm{kg}^{-1} \mathrm{~N}$. The $\mathrm{N}$ rate that produced maximum yield generally decreased as water potential decreased, and was between $60-80 \mathrm{mg} \mathrm{kg}^{-1}$ for all but the wettest and driest soils. The reduction in herbage accumulation particularly at low water potential $(\mathrm{pF}>2.7)$ with higher $\mathrm{N}$ levels ( $>80 \mathrm{mg} \mathrm{kg}^{-1}$ ) may be due to salinity effect /osmotic effect on plants where there is not enough moisture to mobilize the applied nutrients. Pier and Doerge (1995) also observed pronounced positive interactions in watermelon with maximum fruit yields occurred at rates of applied $\mathrm{N}$ between $200-270 \mathrm{~kg} \mathrm{ha}^{-1}$ at a mean soil water tension of $6 \mathrm{kPa}$. Fertilizer use efficiency is a function of available soil water (Fiez et al., 1994) because of the effect water potential has on nutrient availability through processes such as movement, dissolution and hydrolysis. 


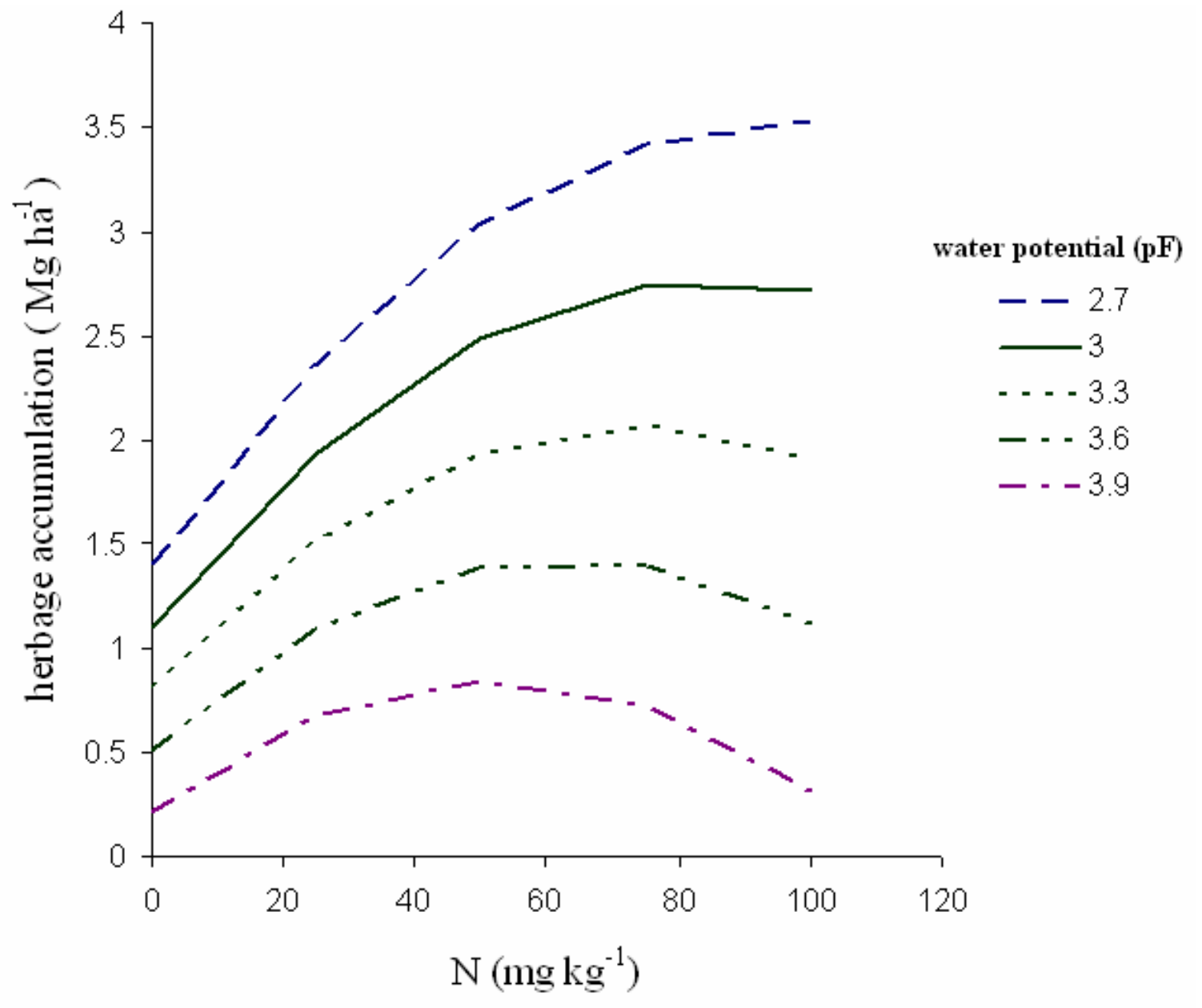

Fig. 3.4.4. Effect of water potential and $\mathrm{N}$ levels on Kentucky bluegrass herbage accumulation.

The herbage accumulation of bluegrass was also influenced significantly by the interaction between $\mathrm{pH}$ and $\mathrm{N}$ level (Fig. 3.4.5). Increasing $\mathrm{pH}$ increased herbage accumulation at all $\mathrm{N}$ levels, especially at higher rates of $\mathrm{N}$. The $\mathrm{N}$ rate that produced maximum yield increased as $\mathrm{pH}$ increased up to $\mathrm{pH}$ 6.5. Decreases in yield were observed as $\mathrm{N}$ rate exceeded $50-80 \mathrm{mg} \mathrm{kg}^{-1}$ when soil $\mathrm{pH}$ was less than 5.5 . This may again be a salinity effect. Winston et al. (1976) observed an increase in recovery of $\mathrm{N}$ as 
well as yield in Timothy grass (Phleum pretense L.) in response to liming on Kachemak silt loam.

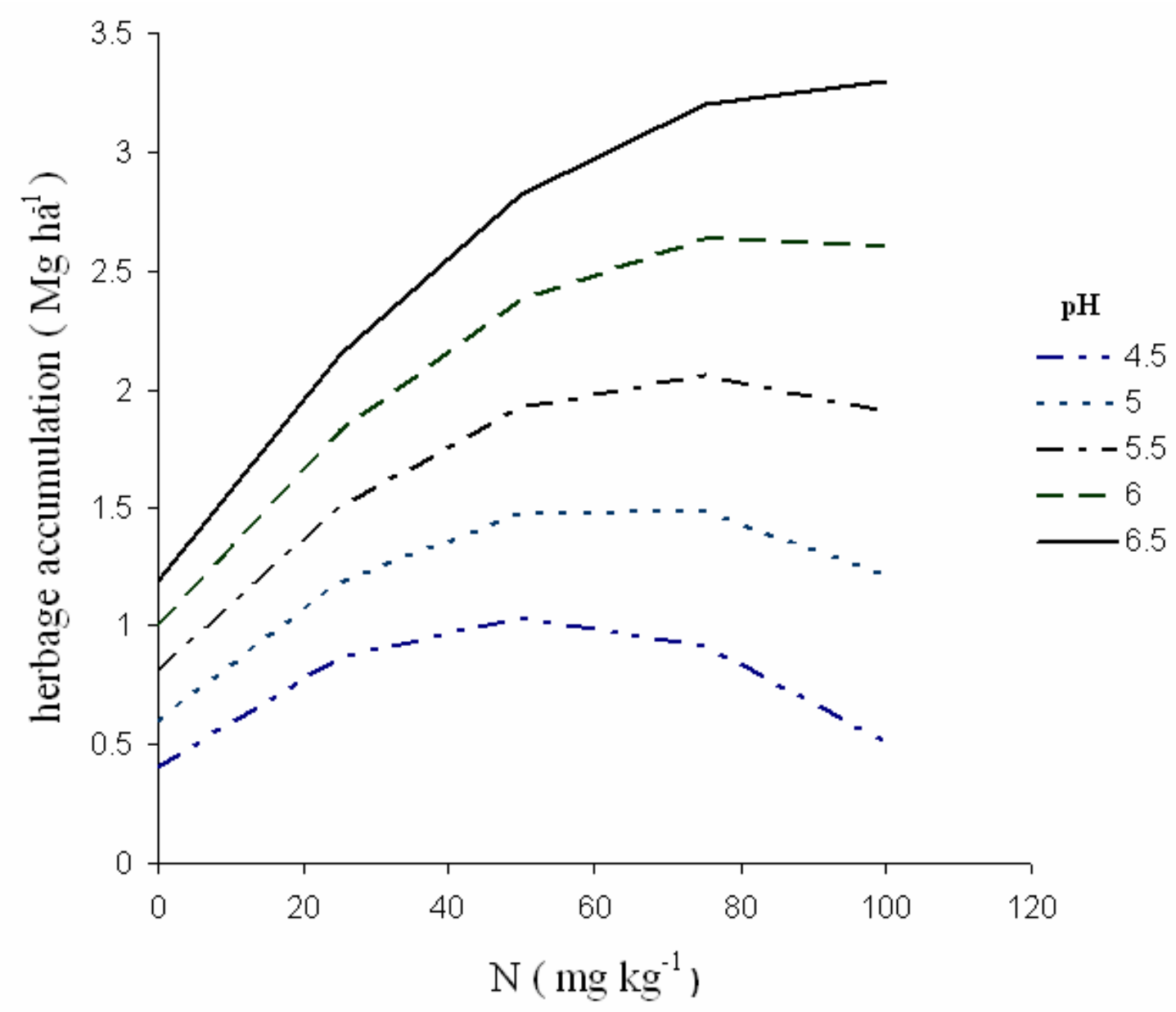

Fig. 3.4.5. Effect of $\mathrm{pH}$ and $\mathrm{N}$ levels on Kentucky bluegrass herbage accumulation

The RSREG using ridge max option in proc step of SAS program provided the optimum levels of these four factors to obtain maximum herbage accumulation (response) in bluegrass (Table 3.4.3). The higher herbage accumulation was observed when water potential $(\mathrm{pF})$ ranges about 2.88 to $3.30, \mathrm{pH}$ ranges 5.5- 6.1, and $\mathrm{N}$ levels 
ranges around $50-70 \mathrm{mg} \mathrm{kg}^{-1}$. These are the optimum conditions to be maintained to get higher herbage accumulation in bluegrass. Small variations of P levels found from 40.0 to $36.0 \mathrm{mg} \mathrm{kg}^{-1}$ in agreement with the observations regarding the ineffectiveness of the $\mathrm{P}$ doses to the herbage accumulation in bluegrass. The water potential, $\mathrm{pH}$ and $\mathrm{N}$ levels showed a significant positive influence on the herbage accumulation.

Table 3.4.3. Predicted herbage accumulation at optimum conditions

$$
\text { Optimum conditions }
$$

\begin{tabular}{lllll}
\hline $\begin{array}{l}\text { Water } \\
\text { potential } \\
(\mathrm{pF})\end{array}$ & $\mathrm{pH}$ & $\mathrm{N}\left(\mathrm{mg} \mathrm{kg}^{-1}\right)$ & $\mathrm{P}\left(\mathrm{mg} \mathrm{kg}^{-1}\right)$ & $\begin{array}{l}\text { Predicted } \\
\text { herbage } \\
\text { accumulation } \\
\left(\mathrm{Mg} \mathrm{h}^{-1}\right)\end{array}$ \\
\hline 3.30 & 5.5 & 50.0 & 40.0 & 2.11 \\
3.26 & 5.5 & 52.2 & 39.9 & 2.26 \\
3.21 & 5.6 & 54.3 & 39.7 & 2.42 \\
3.17 & 5.6 & 56.3 & 39.5 & 2.59 \\
3.13 & 5.7 & 58.2 & 39.1 & 2.77 \\
3.08 & 5.7 & 60.0 & 38.8 & 2.96 \\
3.04 & 5.8 & 61.1 & 38.4 & 3.16 \\
3.00 & 5.9 & 63.7 & 37.9 & 3.37 \\
2.96 & 5.9 & 65.6 & 37.4 & 3.59 \\
2.92 & 6.0 & 67.3 & 36.9 & 3.82 \\
2.88 & 6.1 & 69.0 & 36.3 & 4.06 \\
\hline
\end{tabular}

Optimum conditions were obtained from ridge analysis

\subsubsection{Nutrient concentration in herbage}

The effect of factors individually and their interactions on nutrient concentration in bluegrass herbage was also studied in this experiment (Table 3.4.4). 
Table 3.4.4. Model significance of nutrient concentration in Kentucky bluegrass

\begin{tabular}{llllll}
\hline Source & N\% & P\% & K\% & Ca\% & Mg\% \\
\hline & & & & & \\
& & & & & \\
& & & & & \\
WP (pF) & $<.0001$ & 0.0182 & $<.0001$ & $<.0001$ & $<.0001$ \\
pH & $<.0001$ & $<.0001$ & $<.0001$ & $<.0001$ & $<.0001$ \\
N & $<.0001$ & 0.0196 & 0.6586 & 0.1367 & 0.1074 \\
P & 0.0518 & $<.0001$ & 0.1043 & 0.7683 & 0.5434 \\
WP*pH & 0.2124 & 0.7635 & 0.0153 & 0.0096 & 0.0195 \\
pH*pH & 0.2138 & 0.1248 & 0.1171 & 0.2569 & 0.0114 \\
WP*N & 0.0240 & 0.3834 & 0.9607 & 0.3680 & 0.4285 \\
pH*N & 0.9009 & 0.4034 & 0.3666 & 0.7763 & 0.5032 \\
$N^{*} \mathrm{~N}$ & 0.0793 & 0.7187 & 0.8787 & 0.9479 & 0.1389 \\
WP*P & 0.3305 & 0.0815 & 0.9564 & 0.8015 & 0.5793 \\
pH*P & 0.2789 & 0.1192 & 0.8094 & 0.7802 & 0.6108 \\
$N^{*} \mathrm{P}$ & 0.0860 & 0.3842 & 0.5833 & 0.9043 & 0.8255 \\
$\mathrm{P}^{*} \mathrm{P}$ & 0.7786 & 0.0117 & 0.6061 & 0.8434 & 0.5638 \\
\hline
\end{tabular}

The nitrogen concentration was significantly influenced by water potential, $\mathrm{pH}, \mathrm{N}$ level, and a water potential by $\mathrm{pH}$ interaction (Table 3.4.4). Higher nitrogen uptake was seen at higher water potential $(\mathrm{pF} 2.7)$ with nitrogen level between 80 and $100 \mathrm{mg} \mathrm{kg}^{-1}$ (Fig. 3.4.6). The higher nitrogen concentration may be due to water potential being in the optimum range for transport associated processes. An impact of water potential and $\mathrm{pH}$ on nitrogen uptake was also found by Aggelides et al. (1999), who found that nitrate concentrations in lettuce were reduced when water potential was reduced from $-30 \mathrm{kPa}$ to $-100 \mathrm{kPa}$. The decrease in $\mathrm{N}$ uptake by Dalbergia sissoo seedlings was observed as irrigation rate decreased from $20 \mathrm{~mm}$ to $8 \mathrm{~mm}$ (Singh and Singh, 2006). Liming along with application of fertilizers enhanced the uptake of nitrogen by meadow plants (Kasperczyk et al., 2005). 


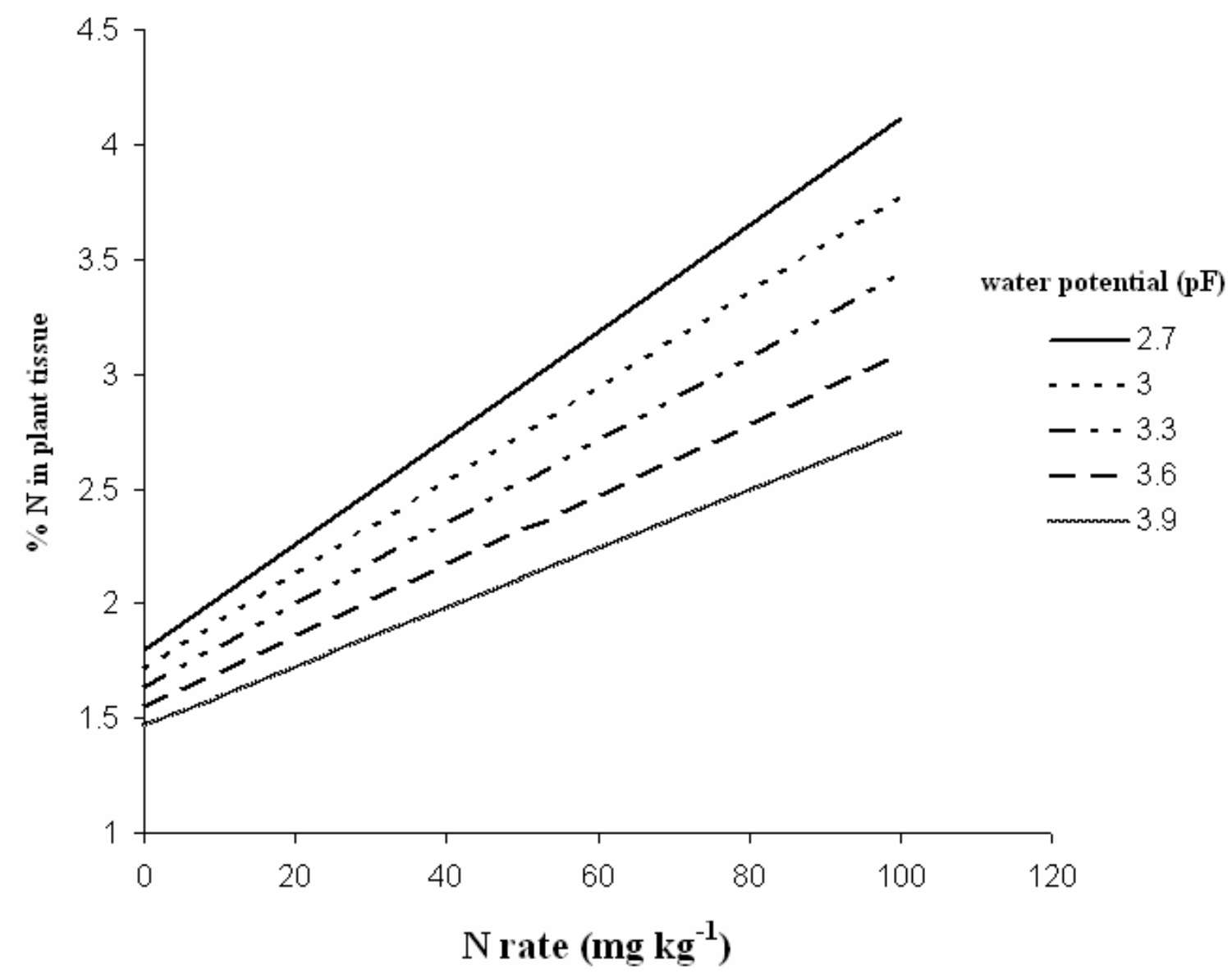

Fig. 3.4.6. Effect of water potential and $\mathrm{N}$ levels on $\mathrm{N}$ concentration in tissue

Phosphorus concentration was affected by water potential, $\mathrm{pH}, \mathrm{N}$ and $\mathrm{P}$ levels, but interactions were not significant (Table. 3.4.4). As water potential increased (low pF) the phosphorus concentration was also increased. This increase may be due to enhancement in diffusion, the principal mechanism for P movement through the soil to root surface. Similar phenomenon was observed by several researchers (Mederski and Wilson, 1960). Increase in $\mathrm{pH}$ also had a significant effect on $\mathrm{P}$ uptake. Mayfield et al. (2002) also observed higher uptake of P by Nandina domestica grown in soil-less media in treatments that received lime compared to un-limed controls. The amount of applied $\mathrm{N}$ increased $\mathrm{P}$ 
uptake in this experiment which was contrast to previous literature. George et al. (1999) observed that a high supply of $\mathrm{N}$ reduced the uptake of $\mathrm{P}$ in young spruce plants (Picea abies L.) due to lower root:shoot ratio. Increased amounts of applied P enhanced the uptake of P in this study. Fageria et al. (1995) also found that higher levels of applied P $\left(0,50\right.$ and $\left.175 \mathrm{mg} \mathrm{kg}^{-1}\right)$ significantly increased nutrient uptake by upland rice (Oryza sativa L.), wheat (Triticum aestivum L.), common bean (Phaseolus vulgaris L.) and corn (Zea mays L.) grown on an oxisol.

The concentrations of $\mathrm{K}, \mathrm{Ca}$, and $\mathrm{Mg}$ in shoots were significantly affected by the levels of water potential and $\mathrm{pH}$ of soil (Fig. 3.4.7-3.4.9). The concentration of $\mathrm{Ca}, \mathrm{Mg}$ and $\mathrm{K}$ was significantly higher at higher levels of $\mathrm{pH}$ and water potential (low $\mathrm{pF}$ values). This enhancement in cation concentration at higher water potentials may be due to optimum soil moisture conditions making these cations available to plants. Similar results were observed for uptake of Ca by perennial ryegrass (Newbould et al., 1971) and for K by corn (Mackay and Barber, 1985) which they attributed to enhancement in transport processes such as mass flow and diffusion. The increase in $\mathrm{pH}$ also enhanced the concentration of cations ( $\mathrm{Ca}, \mathrm{Mg}$, and $\mathrm{K}$ ) in this experiment. Kasperczyk et al. (2005) also observed an increase in concentrations of calcium and magnesium in meadow plants with the application of lime. The concentration of potassium in herbage was not affected by incidental supply of $\mathrm{K}$ in applied $\mathrm{P}\left(\mathrm{KH}_{2} \mathrm{PO}_{4}\right)$ in this study, but it was affected by levels of water potential and $\mathrm{pH}$. 


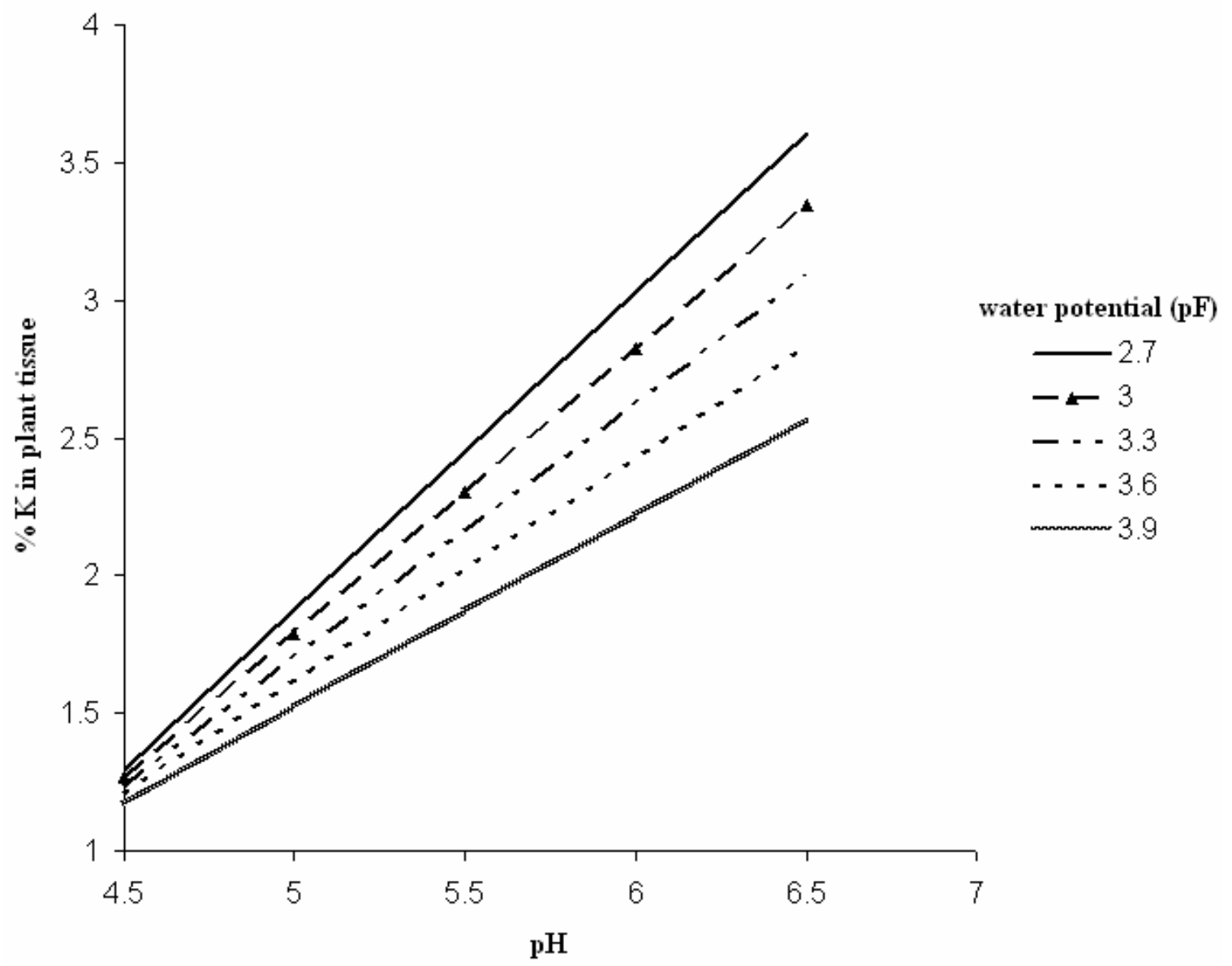

Fig. 3.4.7. Effect of water potential and $\mathrm{pH}$ on $\mathrm{K}$ concentration in tissue 


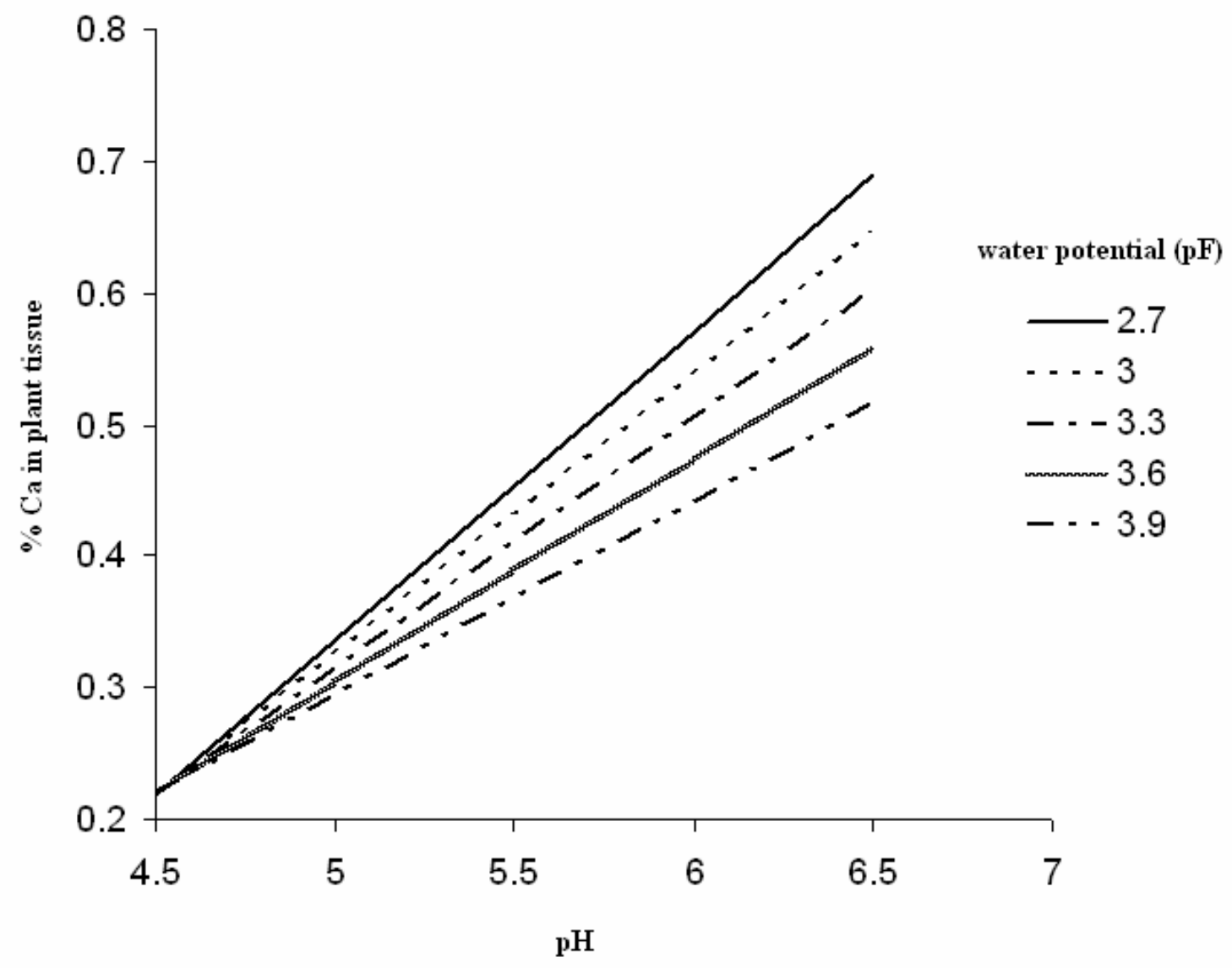

Fig. 3.4.8. Effect of water potential and $\mathrm{pH}$ on $\mathrm{Ca}$ concentration in tissue 


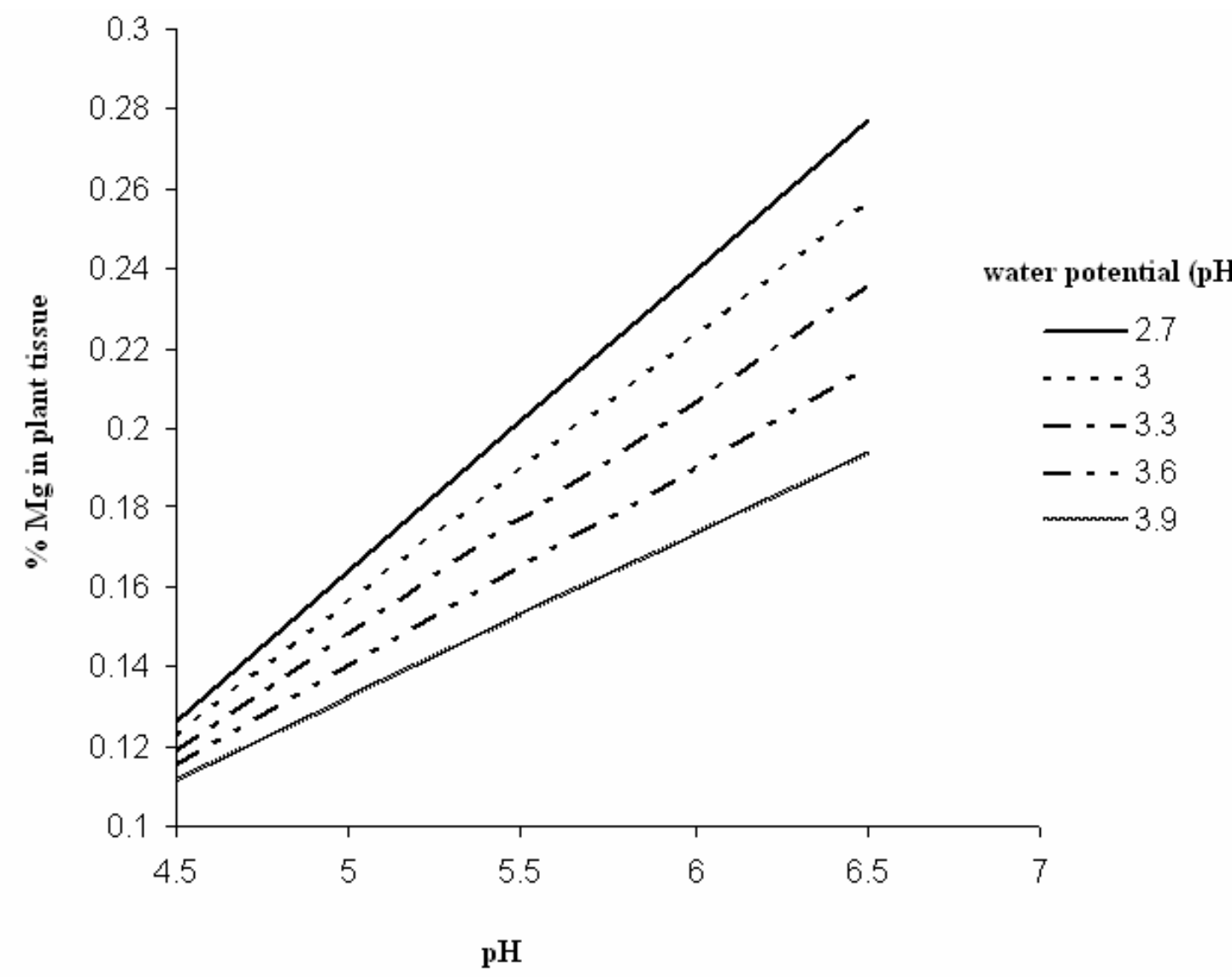

Fig. 3.4.9. Effect of water potential and $\mathrm{pH}$ on $\mathrm{Mg}$ concentration in tissue

Response surface methodology used in this study has provided a response function for Kentucky bluegrass herbage accumulation in an acidic pasture soil of the Appalachian region. The function also allows for prediction yield response, indicating that an improvement of forage production can be achieved. Optimal levels of growth determining factors were also derived to maximize the production of bluegrass. Nutrient concentrations in bluegrass herbage were affected by water potential, $\mathrm{pH}, \mathrm{N}$ and $\mathrm{P}$ levels in a similar way. It was concluded that water potential and $\mathrm{pH}$ had significant impacts on 
uptake of N, P, Ca, Mg, and K. Significant interaction effects of WP x N and WP x pH were observed on concentration of $\mathrm{N}$ and cations respectively.

\subsection{REFERENCES}

Adams, F. 1984. Crop response to lime in the Southern United States, p.211-259. In F. Adams (ed.) Soil Acidity and Liming. American Society of Agronomy. Madison, WI, USA.

Aggelides, S., I. Assimakopoulos, P. Kerkides, and A. Skondras. 1999. Effects of soil water potential on the nitrate content and the yield of lettuce. Commun. Soil Sci. Plant Anal. 30:235-243.

Alabi, H.E., R.C. Sorensen, D. Knudsen, and G.W. Rehm. 1986. Comparison of several lime requirement methods on coarse textured soils of northeastern Nebraska. Soil Sci. Soc. Am. J. 50:937-947.

Caraballo, A.D., D. E. Morillo, J. Faria-Marmol, and L.R. McDowell. 1997. Frequency of defoliation and nitrogen and phosphorus fertilization on Andropogon guyanas Kunth. 1. Yield, crude protein content, and in vitro digestibility. Commun. Soil Sci. Plant Anal. 28:823-831.

Chapman, H.D. 1965. Cation exchange capacity. p. 891-901. In C. A. Black (ed.) Methods of soil analysis Part 2: Chemical and Microbiological Properties. Am. Soc. Agron., Madison, WI, USA. 
Clark, D.A., and S.L. Harris. 1996. White clover or nitrogen fertilizer for dairying?. p.107-114. In D. R. Woodfield (ed.) New Zealand Grassl. Assoc. Lincoln Univ., Christchurch, NZ.

Fageria, N.K., F.J.P. Zimmermann, and V.C. Baligar. 1995. Lime and phosphorus interactions on growth and nutrient uptake by upland rice, wheat, common bean, and corn in an oxisol. J. Plant. Nutr. 18:2519-32.

Fiez, T.E., B.C. Miller, and W.L. Pan. 1994. Winter wheat yield and grain protein across varied landscape positions. Agron. J. 86:1026-1032.

Foloni, J.S.S., C. A. Rosoleum, R. A. Garcia, and A. Rodrigo. 2006. Effect of liming and ammonium sulfate in cotton. Rev. Bras. Cienc. Solo. 30:433-442. (Abstract only)

George, E., S. Kircher, P. Schwartz, A. Tesar, and B. Seith. 1999. Effect of varied nitrogen supply on growth and nutrient uptake of young Norway spruce plants grown in a shaded environment. J. Plant Nutr. Soil Sci.. 162:301-307.

Gutierrez-Boem, F.H., and G.W. Thomas. 1998. Phosphorus nutrition affects wheat response to water deficits. Agron. J. 90:166-171.

Harvey, R. W., J.P. Mueller, J.A. Barker, M. H. Poore, and J. P. Zublena. 1996. Forage characterstics, steer performance, and water quality from bermuda grass pastures fertilized with two levels of nitrogen from swine lagoon effluent. J. Anim. Sci. 74:457-464.

Hockman, Z., D.C. Edmeads, and E. White. 1992. Changes in effective cation exchange capacity and exchangeable aluminium with soil $\mathrm{pH}$ in lime-amended field soils. Aust. J. Agr. 30:177-187. 
Holford, I.C.R., and G.J. Crocker. 1994. Long-term effects of lime on pasture yields and response to phosphate fertilizers on eight acidic soils. Aust. J. Agr. 45:1045-1062.

Houng, K.H., T.T. Chen, and T.P. Liu. 1967. Effect of liming on the nutrient uptake of rice plants. Zhongguo Nongye Huaxuehuizhi.70:1-11. (Abstract only)

Johnson, C.A., B.A. Reiling, P. Mislevy, and M.B. Hall. 2001. Effects of nitrogen fertilization and harvest date on yield, digestibility, fiber and protein fractions of tropical grasses. J. Anim. Sci. 79: 2439-2448.

Juo, A.S.R., and F.O. Uzu. 1977. Liming and nutrient interactions in two ultisols from southern Nigeria. Plant and Soil 47:419-20.

Kasperczyk, M., W. Szewczyk, and P. Kacorzyk. 2005. Effects of liming, mineral fertilizing and oversowing on macroelement uptakes by meadow plants. Towarzystwo Chemii i Inzynierii Ekologicznej 12:821-825. (Abstract only)

Koerselman, W., M.B. Van Kerkhoven., and J.T.A. Verhoeven. 1993. Release of inorganic N, P and K in peat soils:Effect of temperature, water chemistry and water level. Biogeochem. 20:63-81.

Lawton, K., and J.A. Vomocil. 1954. The dissolution and migration of phosphorus from granular superphosphate in some Michigan soils. Soil Sci. Soc. Am. Proc. 18:2632.

Mackay, A.D., and S. A. Barber. 1985. Soil moisture effects on root growth and phosphorus uptake by corn. Agron. J. 77:519-523.

Malhi, S.S., H. Loeppky, H. Coulman, B. Gill, K.S. Curry, and P. Plews. 2004. Fertilizer nitrogen, phosphorus, potassium, and sulfur effects on forage yield and quality of 
timothy hay in the Parkland Region of Saskatchewan. J. Plant Nutr. 27:1341 1360.

Mayfield, J.L., J.L. Sibley, E.H. Simonne, and D.J. Eakes. 2002. Effect of liming materials on media $\mathrm{pH}$ and overall growth and nutrition of dwarf nandina. J. Plant Nutr. 25:1377-87.

Mederski, H.J., and J.H. Wilson. 1960. Relation of soil moisture to ion absorption by corn plants. Soil Sci. Soc. Am. Proc. 24:149-152.

Mendoza, R.E., M.B. Collantes, J. Anchorena, and S. Cazinzos. 1995. Effects of liming and fertilization on forage yield and vegetation in dry heath soils from Tierra del Fuego. J. Plant Nutr. 18:401- 420.

Menzies, N.W., L.C. Bell, and D.G. Edwards. 1994. Exchange and solution phase chemistry of acid, highly weathered soils.I. Characterstics of soils and effect of lime and gypsum amendments. Aust. J. Soil Res. 32:251-267.

Myers, R.H., and D.C. Montgomery. 1995. Response Surface Methodology: Process and Production in Optimization Using Designed Experiments. John Wiley \& Sons, Inc, New York, NY, USA.

Newbould, P., R. Taylor, and K.R. Howse. 1971. The absorption of phosphate and calcium from different depths in soil by swards of perennial ryegrass. J. Brazil Grassl. Soc. 26:201-208.

Oliver, H., A., F. Lotter, and G. Lemcke. 2001. Loss on ignition as a method for estimating organic and carbonate content in sediments: reproducibility and comparability of results. J. Paleolimnol. 25:101-110. 
Paula, M.B., F.D. Nogueira, H. Andrade, and J.E. Pittis. 1987. Effect of liming on dry matter yield of wheat in pots of low humic gley soil. Plant and Soil. 97:85-91.

Pier, J.W., and T.A. Doerge. 1995. Nitrogen and water interactions in trickle-irrigated watermelon. Soil Sci. Soc. Am. J. 59:145-150.

Prado, R.D., F.M. Fernandes, and W. Natale. 2002. Lime and slag application evaluated by leaf analysis for macronutrient accumulation and export in sugarcane. Scientia Agricola. 59: 129-135. (Abstract only)

Ramesh, V., and P.K. Chonkar. 2001. Growth and uptake of nutrients by rice and lettuce grown on an acid sulfate soil amended with fly ash and lime. J. Indian Soc. Soil Sci. 49:222-225.

Rechcigal, R.W., and G.G. Payne. 1990. Comparison of microwave digestion system to other digestion methods for plant tissue analysis. Commun. Soil Sci. Plant Anal. 21:2209-2218.

Ryan, J., and G.W. Smillie. 1975. Liming in relation to soil acidity and P fertilizer effieciency. Commun. Soil Sci. Plant Anal. 6:409 - 419.

Saeed, I.A.M., and A.H. El-Nadi. 1998. Forage sorghum yield and water use efficiency under variable irrigation. Irrig. Sci. 18:67-71.

Sanchez, P.A., and G. Uehara. 1980. Management considerations for acid soils with high phosphorus fixation capacity. p.471-514. In The role of phosphorus in agriculture. American Society of Agronomy, Madison, WI, USA. 
Singh, B., and G. Singh. 2006. Effects of controlled irrigation on water potential, nitrogen uptake and biomass production in Dalbergia sissoo seedlings. Environ. Exper. Bot. 55: 209-219.

Staputis, J. 2000. Interacting effects of liming, fertilization and plant breeding in some Lithuanian soils in relation to environmental protection. NATO Science Series. 69:1389-1839. (Abstract only)

Sternberg, R.W., and J.S. Creager. 1961. Comparative efficiencies of size analysis by hydrometer and pipette methods. J. Sediment Petrol. 31:96-100.

Wermke, M. 1975. Relationship between plant nutrient uptake and constituents of meadow fescue (Festuca pratensis L.) in relation to the suitability for conservation. Wirtschaftseigene Futter 21:304-11. (Abstract only)

Wilkinson, S.R., and G.W. Langdale. 1974. Fertility needs of the warm-season grasses. p. 119-145. In Forage Fertilization. ASA, CSSA, and SSSA, Madison, WI,USA.

Winston, M.L., P.F. Martin, and G.R. Smith. 1976. Lime and nitrogen influence on timothy yield and composition. Agron. J. 68:881-885. 


\section{CHAPTER IV}

\section{Available Water Effect On Optimum pH, Nitrogen and Phosphorus Requirements II. Kentucky Bluegrass - White Clover}

\subsection{ABSTRACT}

The productivity of grasslands depends on soil factors such as water potential, $\mathrm{pH}$, $\mathrm{N}$ and $\mathrm{P}$ levels. There is a need to understand the interactive effects of these factors on yield of grasslands. Response surface methodology was applied to optimize herbage accumulation of a bluegrass-white clover mixture for an acidic pasture soil. The effects of two levels of water potential (WP) and five levels each of $\mathrm{pH}, \mathrm{N}$, and $\mathrm{P}$ fertilizer additions were evaluated. Water potential, $\mathrm{pH}, \mathrm{N}$ and $\mathrm{P}$ were significant main effects, as were the interactions WP $x \mathrm{pH}, \mathrm{WP} \times \mathrm{N}, \mathrm{pH} \times \mathrm{pH}, \mathrm{P} \times \mathrm{P}, \mathrm{pH} \times \mathrm{N}$, and $\mathrm{N} \times \mathrm{P}$. The order of influence of factors on herbage accumulation was $\mathrm{WP}>\mathrm{N}>\mathrm{pH}>\mathrm{WP} \times \mathrm{N}>\mathrm{pH} \times \mathrm{pH}>\mathrm{P}$ $>$ WP $\times \mathrm{pH}>\mathrm{N} \times \mathrm{P}>\mathrm{pH} \times \mathrm{N}>\mathrm{P} \times \mathrm{P}$. Optimum levels of these four factors to maximize herbage accumulation were determined by using the RSREG procedure. These results have implications for how to divide pastures into management zones for optimal bluegrass-white clover production. 


\subsection{INTRODUCTION}

Legumes are an important component of grasslands and have been shown to increase herbage dry matter yield and quality (Malhi et al., 2002; Rhodes and Ortega, 1997). White clover (Trifolium repens L.) is one of the important legume crops in temperate pastures and can provide acceptably high levels of production under low-input systems (Rochon et al., 2004). White clover is commonly sown in grasslands of temperate zones around the world in order to improve fodder quality and to fix atmospheric nitrogen (Ledgard, 2001).

Remediation of soil acidity is crucial for improving pasture soil quality and increasing forage yield. Liming to remediate acidic soils has a longer history than any other forms of fertility amendments (Gardner and Garner, 1953). Liming results in changes in chemical and physical properties of soil which improve conditions for plant growth (Menzies et al., 1994). Red clover and lime increased the productivity and nutrient uptake by all other plants in a crop rotation, which also led to imbalance in $\mathrm{N}$ and K in the soil that could be corrected by fertilization (Shempel and Kukresh, 1975). Therefore, it is essential to include legumes in reclaimed acidic pasture lands to maximize productivity of these low-input systems.

There is a need to study the interactions of liming and nutrient levels of soil to derive better management practices for grasslands. Several long-term experiments demonstrated the importance of basic slag and P-rich fertilizers in raising the productivity of relatively infertile permanent pasture by promoting growth of white clover (Elliott and Thomas, 1934; Arnold et al., 1976). The important role of P fertilizers along with lime, $\mathrm{K}$, and $\mathrm{N}$ in improving pasture quality and output was observed in the Welsh uplands 
(Milton and Davies, 1947; Jones, 1967). Cockayne (1956) observed that the topdressing with super phosphate was a major factor for increasing pasture production and livestock output. Ozgur and Sebahattin (2006) found that phosphorus treatments significantly affected dry matter yield and crude protein yield in white clover cultivars. Nitrogen fixing plants have a greater need for P than nitrate-supplied plants (Israel, 1987). N inputs were recognized as equally important to increase herbage production and provide potential to absorb other essential elements from soil such as potassium (Reith et al., 1961).

Soil water content is an essential growth factor which can influence the success of any application of amendments and fertilizers. It had significant effect on nutrient release from applied fertilizers as well as mineralization reactions (Koerselman et al., 1993). Fertilizer use efficiency is a function of available water (Fiez et al., 1994; GutierrezBoem and Thomas, 1998).

Forage can be produced on acidic soils with appropriate agronomic practices. These practices will be affected by available soil water. Given the undulating topography of many Appalachian pastures and the resulting variability in soil water content, there is a need to understand the interactions between soil water, $\mathrm{pH}, \mathrm{N}$ and $\mathrm{P}$ application rates. This study was designed to derive yield response model for legume based pastures, and to quantify the interactions of water potential, $\mathrm{pH}, \mathrm{N}$ and $\mathrm{P}$ levels.

\subsection{MATERIALS AND METHODS}

An acidic soil $(\mathrm{pH}<5.5)$ was collected near Morgantown, WV from a Culleoka Westmoreland map unit, air-dried and passed through a $2 \mathrm{~mm}$ sieve. Soil $\mathrm{pH}$ was 
determined using a glass membrane electrode; texture by the pipette method (Sternberg and Creager, 1961); organic matter content by loss on ignition (Oliver et al., 2001); and CEC by the ammonium acetate method (Chapman, 1965). Lime response curve for the collected soil was developed by direct $\mathrm{Ca}(\mathrm{OH})_{2}$ titration method (Alabi et al., 1986). The soil moisture characteristic curve was determined using a dew-point potentiometer (Decagon Model WP4-T) and gravimetry. All determinations were done in triplicate.

Sufficient $\mathrm{Ca}(\mathrm{OH})_{2}$ was added to separate sub-samples produce different $\mathrm{pH}$ levels based on the lime response curve to establish a range of final soil $\mathrm{pH}$ from 4.5 to 6.5 in approximately 0.5 increments. Limed soils were incubated at field capacity for one week, or until equilibrium $\mathrm{pH}$ was reached. Soils were again air-dried and stored until use. The experiment was a centrally composite rotatable design with three replications in order to reduce the number of experimental units (Myers and Montgomery, 1995) (Appendix. (Table A5)). Soil was placed in pots $(30.5 \mathrm{~cm} \times 30.5 \mathrm{~cm} \times 20 \mathrm{~cm})$ and five fertilizer rates were established by incorporating nitrogen as $\left(\mathrm{NH}_{4} \mathrm{NO}_{3}\right.$ ) or phosphorus (as $\mathrm{KH}_{2} \mathrm{PO}_{4}$ ) to the soil. Nitrogen was added at $0,10,25,50$ and $100 \mathrm{mg} \mathrm{N} \mathrm{kg}^{-1}$ soil. Phosphorus was added to give final phosphorus concentrations of $0,10,20,40$ and $80 \mathrm{mg}$ $\mathrm{P} \mathrm{kg}^{-1}$ soil. Two water contents, near field capacity ( $\mathrm{pF} 2.7$ ) and just above the permanent wilting point ( $\mathrm{pF}$ 3.9), as determined from the soil-water characteristic curve were imposed and maintained using a sensor-based irrigation system (NETAFIM Flori I). Water content was measured regularly by potentiometer (Decogon Model WP4 -T).

Pots were seeded with bluegrass (Poa pratensis L.), white clover (Trifolium repens $L$.), or a $75 \%$ bluegrass - $25 \%$ white clover mixture (weight basis). White clover seeds were inoculated with Rhizobium trifoli just before seeding. Every three weeks a 
sample of the soil solution before watering was drawn with a soil solution sampler (Rhizon SMS) and analyzed for $\mathrm{Ca}^{2+}, \mathrm{PO}_{4}{ }^{3-}, \mathrm{NH}_{4}{ }^{+}$and $\mathrm{NO}_{3}{ }^{-}$by ion chromatography (DX300, Dionex Corp). At the end of the experiment (60 days after sowing) herbage accumulation was measured by clipping at ground level and drying the herbage at $105{ }^{\circ} \mathrm{C}$ for 48 hours. Nutrient concentration was determined in herbage by wet digestion with concentrated $\mathrm{HNO}_{3}$ using microwave (MARS 5, CEM) (Rechcigal and Payne 1990). The extracts from this wet digestion were used to determine nutrient concentrations by ICPOES (Perkin Elmer P400, Norwalk, CT). Nutrient concentrations were expressed on a tissue dry matter basis.

Herbage accumulation data were analyzed using a response surface methodology and the PROC RSREG procedure with Ridge max option in SAS (ver 9.1, SAS Institute, Cary, NC, USA). Herbage accumulation was the response variable and water potential, $\mathrm{pH}, \mathrm{N}$, and $\mathrm{P}$ rates were added to construct model main effects. The linear, quadratic, and cross product terms of these factors were also determined. A step-wise regression procedure was used to determine the best model. Adjusted $\mathrm{R}^{2}$ and $\mathrm{Cp}$ statistics were used to select model parameters. The effect of factors as linear, quadratic, and interaction (cross product) coefficients on response variable (dry matter yield) was tested for adequacy and fitness by analysis of variance. Nutrient concentrations in herbage were analyzed to study the effect of water potential, $\mathrm{pH}, \mathrm{N}$ and $\mathrm{P}$ levels. 


\subsection{RESULTS AND DISCUSSION}

The soil texture of the pot medium was a silt clay loam (34.3\% clay; $44.0 \%$ silt), with an initial $\mathrm{pH}$ of $4.8,9.2 \%$ organic matter, $42.5 \mathrm{ppm} \mathrm{Ca}, 9.8 \mathrm{ppm} \mathrm{Mg}, 40.8 \mathrm{ppm} \mathrm{K}$, $4.06 \mathrm{ppm} \mathrm{P}$, and a CEC of $15.84 \mathrm{cmol}_{\mathrm{c}} \mathrm{kg}^{-1}$. The lime response curve was linear from $\mathrm{pH}$ 5.2 to 6.5 (Appendix (Fig. A1)). On average water potential (pF) was 2.70 in the field capacity treatment and 3.91 in the near wilting point treatment of both were maintained during the entire period of the experiment which were gravimetrically equal to $16 \%$ and 30\%, respectively (Appendix (Fig. A2-A3)).

\subsubsection{Yield model}

Analysis of variance showed that the model significantly predicted herbage accumulation (response variable) despite the presence of a significant lack of fit (Table 4.4.1). A residual plot indicated no pattern in the residuals (Fig. 4.4.1), but a large variance. High variance in residual data from stratum may be due to a larger effect of treatments. The lack of fit term was not significant when mean values were used (Fig. 4.4.2). These results suggest that a factor affecting yield was not captured by the treatments selected.

Table 4.4.1. Analysis of Variance for the response model

\begin{tabular}{llrrrl}
\hline Source & df & Sum of Squares & Mean Square & F Ratio & Prob > F \\
\hline Model & 13 & 143.27 & 11.02 & 122.26 & $<.0001$ \\
Error & 82 & 7.39 & 0.09 & & \\
Lack Of Fit & 16 & 5.72 & 0.35 & 14.17 & $<.0001$ \\
Pure Error & 66 & 1.66 & 0.02 & & \\
C. Total & 95 & 150.66 & & & \\
\hline
\end{tabular}




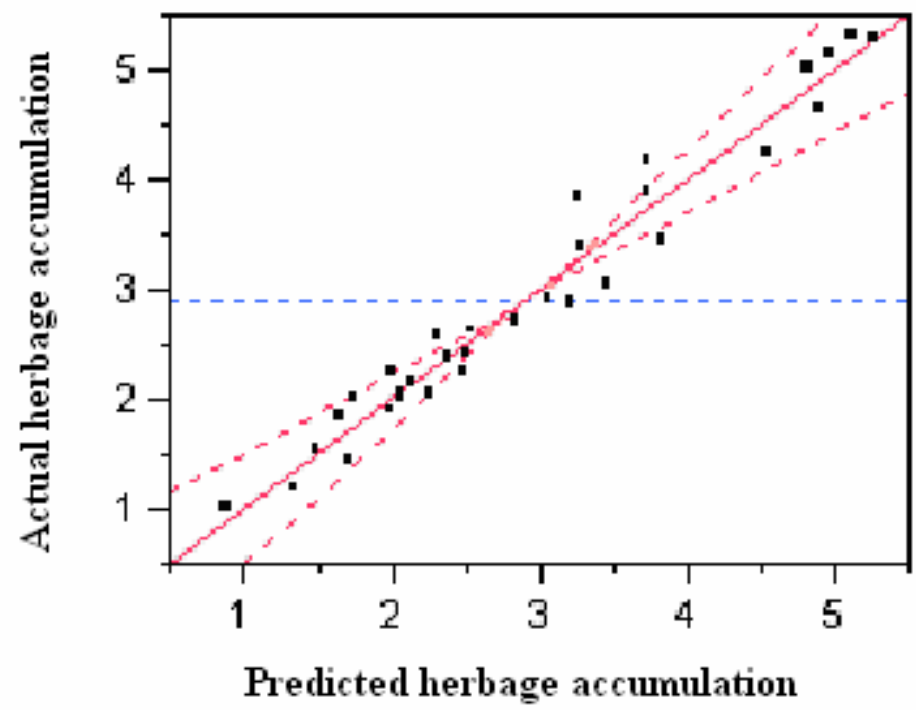

Fig. 4.4.1. Actual vs. predicted herbage accumulation using the model. Dashed lines indicate the $95 \%$ confidence interval.

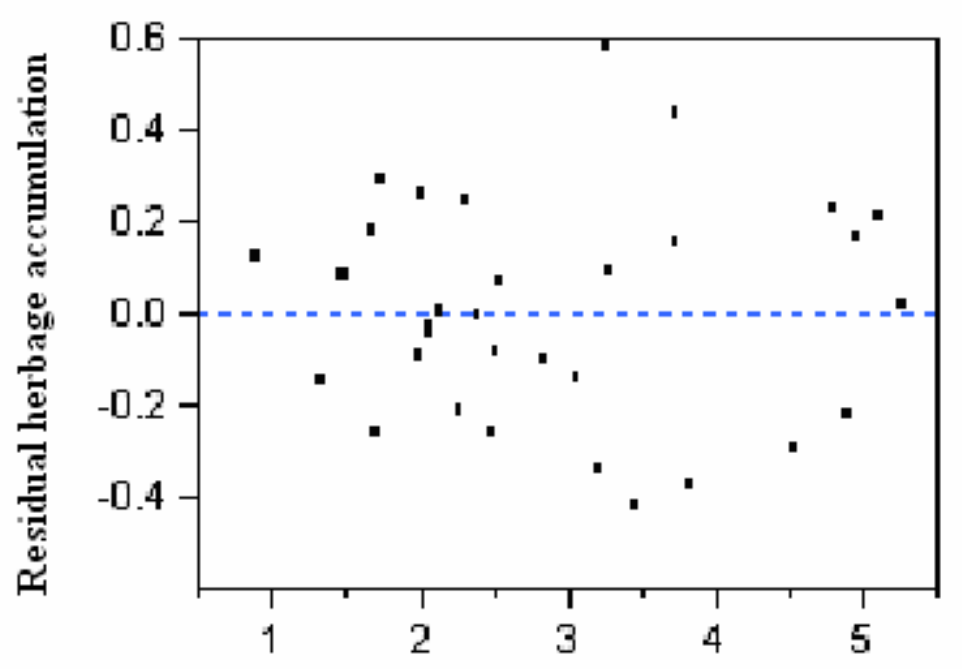

Predicted herbage accumulation

Fig. 4.4.2. Residual vs. Predicted values of herbage accumulation using the model 
Water potential, $\mathrm{pH}, \mathrm{N}$ and $\mathrm{P}$ were the main effects that influenced herbage accumulation $(\mathrm{P}<0.05)$ (Table. 4.4.2). The cross product terms of water potential $\mathrm{x} \mathrm{N}$, water potential $\times \mathrm{pH}, \mathrm{N} \times \mathrm{P}, \mathrm{pH} \times \mathrm{N}$ as well as quadratic terms of $\mathrm{pH}$ and $\mathrm{P}$ also showed significant effects on herbage accumulation.

Water potential had the largest influence on bluegrass-white clover herbage accumulation, as indicated by sum of squares followed by $\mathrm{N}, \mathrm{pH}$ and $\mathrm{P}$ levels. The order of influence of interaction terms on herbage accumulation was WP $\mathrm{x} \mathrm{N}>\mathrm{pH} \times \mathrm{pH}>\mathrm{WP}$ $\mathrm{x} \mathrm{pH}>\mathrm{N} \times \mathrm{P}>\mathrm{pH} \times \mathrm{N}>\mathrm{P} \times \mathrm{P}$. These terms were used to determine the response surface function.

$$
\begin{aligned}
& \mathrm{Y}=-(1.24 * \mathrm{WP})+(0.79 * \mathrm{pH})+(0.02 * \mathrm{~N})+(0.01 * \mathrm{P})-0.40 *(\mathrm{WP}- \\
& 3.305) *(\mathrm{pH}-5.5)-0.01 *(\mathrm{WP}-3.305) *(\mathrm{~N}-30.625)-0.67 *(\mathrm{pH}-5.5) *(\mathrm{pH}- \\
& 5.5)+0.01 *(\mathrm{pH}-5.5) *(\mathrm{~N}-30.625)+0.0005 *(\mathrm{~N}-30.305) *(\mathrm{P}-25)+ \\
& 0.0001 *(\mathrm{P}-25) *(\mathrm{P}-25)
\end{aligned}
$$

where $\mathrm{Y}$ is herbage accumulation of the bluegrass-white clover mixture in $\mathrm{Mg} \mathrm{ha}^{-1}$, WP is water potential $(\mathrm{pF}), \mathrm{N}$ and $\mathrm{P}$ are levels of nitrogen and phosphorus $\left(\mathrm{mg} \mathrm{kg}^{-1}\right)$ respectively. 
Table 4.4.2. ANOVA for effect of factors and their interactions on herbage accumulation of bluegrass and white clover mixture

\begin{tabular}{|c|c|c|c|c|c|}
\hline Source & df & Estimates & $\begin{array}{r}\text { Sum of } \\
\text { Squares }\end{array}$ & F Ratio & Pr $>$ F \\
\hline $\mathrm{WP}(\mathrm{pF})$ & 1 & -1.239285 & 53.966483. & 383.9171. & $<.0001$ \\
\hline $\mathrm{N}$ & 1 & 0.026478 & 19.2438650 & 136.9007 & $<.0001$ \\
\hline $\mathrm{pH}$ & 1 & 0.790049 & 13.666329 & 97.22210 & $<.0001$ \\
\hline $\mathrm{P}$ & 1 & 0.010981 & 1.9416700 & 13.81300 & 0.0004 \\
\hline $\mathrm{WP} * \mathrm{~N}$ & 1 & -0.014851 & 4.423316 & 31.4674 & $<.0001$ \\
\hline $\mathrm{pH} \mathrm{H}^{*} \mathrm{pH}$ & 1 & -0.674432 & 3.281965 & 23.3479 & $<.0001$ \\
\hline $\mathrm{WP} * \mathrm{pH}$ & 1 & -0.402648 & 1.42070 & 10.1318 & 0.0021 \\
\hline $\mathrm{N}^{*} \mathrm{P}$ & 1 & 0.000530 & 1.267860 & 9.0196 & 0.0036 \\
\hline $\mathrm{pH} \mathrm{H}^{*} \mathrm{~N}$ & 1 & 0.015327 & 1.161047 & 8.2597 & 0.0052 \\
\hline $\mathrm{P} * \mathrm{P}$ & 1 & 0.000197 & 0.774595 & 5.5105 & 0.0213 \\
\hline $\mathrm{pH} * \mathrm{P}$ & 1 & -0.013973 & 0.555554 & 3.9522 & 0.0502 \\
\hline $\mathrm{WP} * \mathrm{P}$ & 1 & -0.005952 & 0.435184 & 3.0959 & 0.0823 \\
\hline $\mathrm{N}^{*} \mathrm{~N}$ & 1 & $6.586 e-5$ & 0.222140 & 1.5803 & 0.2123 \\
\hline
\end{tabular}

Based on parameter estimates, as water potential increased (drier soil conditions), herbage accumulation decreased (Table 4.4.2). The positive sign on parameter estimates of $\mathrm{N}, \mathrm{pH}$ and $\mathrm{P}$ indicate that increasing soil $\mathrm{pH}, \mathrm{N}$ and $\mathrm{P}$ fertilization increased herbage accumulation (Table 4.4.2).

The water potential by $\mathrm{N}$ interaction showed that in addition to increasing herbage accumulation as $\mathrm{pF}$ decreased (increase in water potential), the rate of increase per unit increase in $\mathrm{N}$ rate increased as $\mathrm{pF}$ decreased (Fig. 4.4.3). Pier and Doerge (1995) also observed pronounced positive interactions in watermelon with maximum fruit yields occuring at rates of applied $\mathrm{N}$ between $200-270 \mathrm{~kg} \mathrm{ha}^{-1}$ at a mean soil water tension of 6 $\mathrm{kPa}$. Fertilizer use efficiency is a function of available soil water (Fiez et al., 1994) because of the effect water potential has on nutrient availability through processes such as movement, dissolution and hydrolysis. 


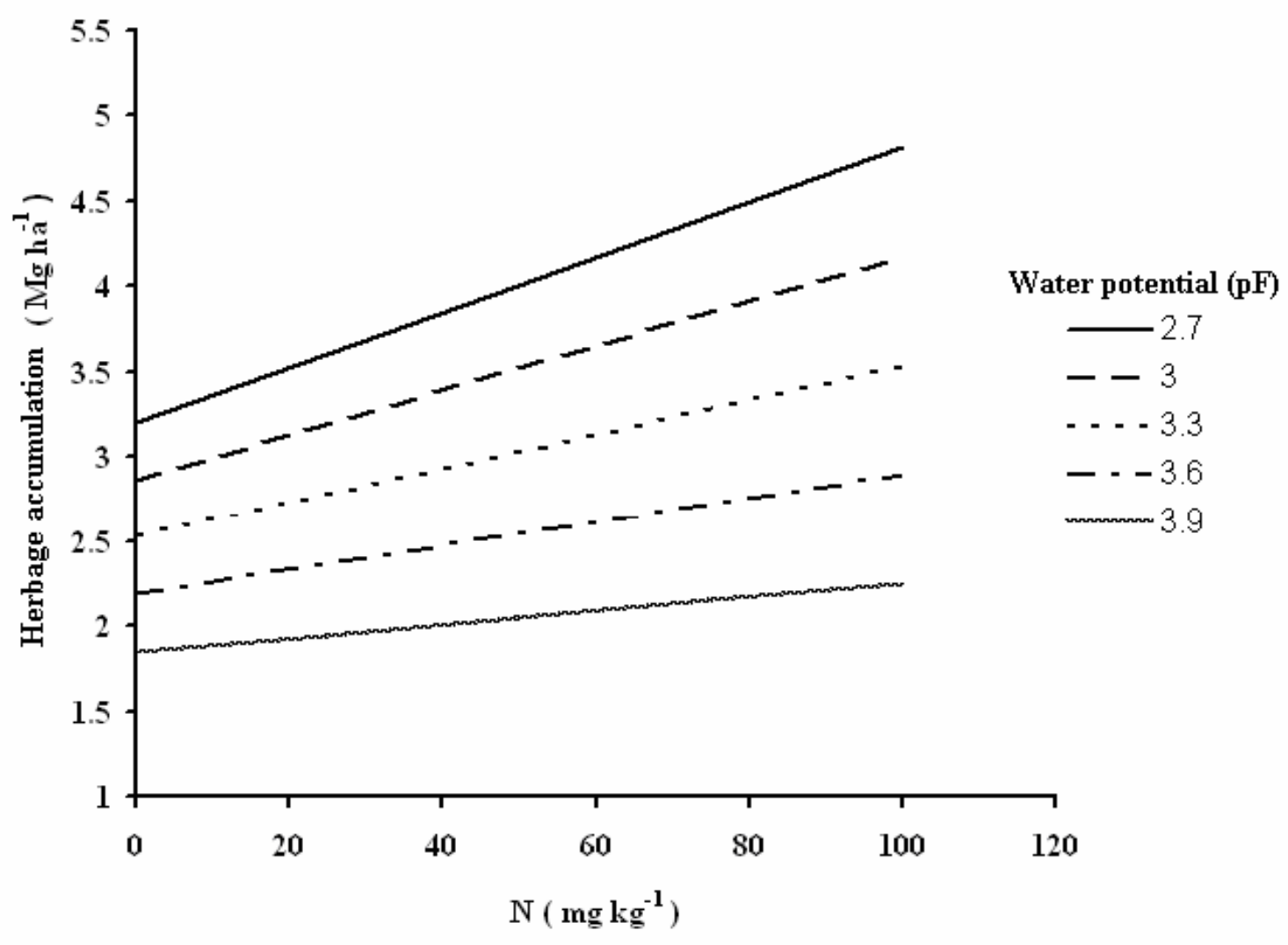

Fig. 4.4.3. Effect of water potential and $\mathrm{N}$ level on herbage accumulation of bluegrass and white clover mixture.

The increase of water potential and $\mathrm{pH}$ had significant effects on herbage accumulation (Fig. 4.4.4). Saeed and El-Nadi (1998) also observed a response in dry matter yield of forage sorghum (Sorghum bicolor L.) to irrigation over two seasons. In their study, the dry matter yields were $16.3,11.8$, and $10.5 \mathrm{Mg} \mathrm{ha}^{-1}$ for frequent $(8 \mathrm{~mm}$ day $^{-1}$ every 7 days), intermediate ( $8 \mathrm{~mm} \mathrm{day}^{-1}$ every 10 days) and infrequent $\left(8 \mathrm{~mm} \mathrm{day}^{-1}\right.$ every 13 days) irrigation regimes respectively. Paula et al. (1987) studied the effect of liming on yields of wheat. They observed maximum dry matter yields of 15.86, 15.88 and $12.53 \mathrm{~g} /$ pot for higher quantities of calcium to reach target $\mathrm{pH}$ 6.0. There have not been 
studies on the effects of both water potential and $\mathrm{pH}$ on dry matter yield as has been done in this study.

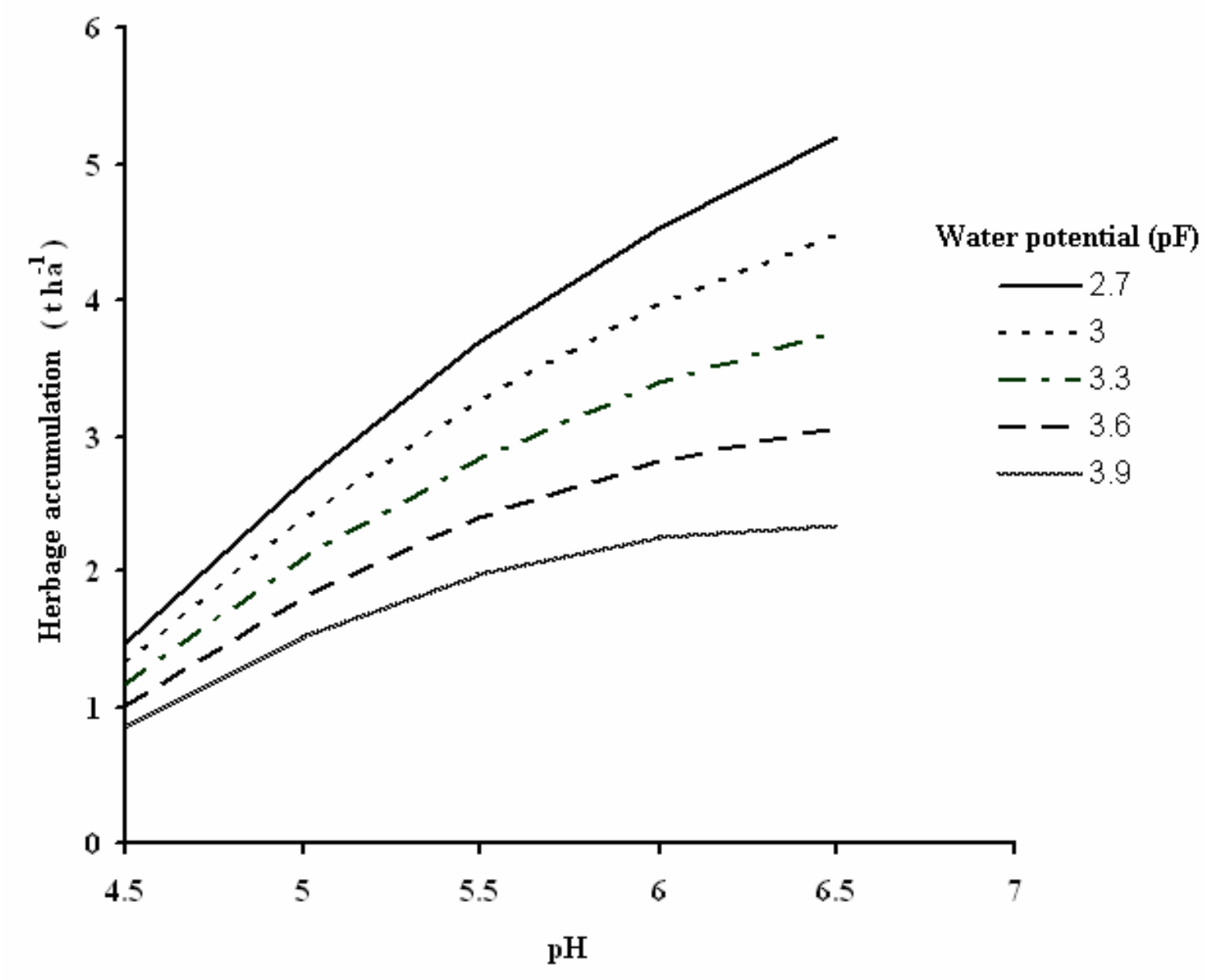

Fig. 4.4.4. Effect of water potential and $\mathrm{pH}$ level on herbage accumulation of bluegrass and white clover mixture.

The interaction between $\mathrm{N}$ and $\mathrm{P}$ levels also showed a statistically significant effect on herbage accumulation (Fig. 4.4.5). As the rate of $\mathrm{P}$ increased $\left(0\right.$ to $80 \mathrm{mg} \mathrm{kg}^{-1}$ ), the increase in $\mathrm{N}$ rate $\left(0\right.$ to $\left.100 \mathrm{mg} \mathrm{kg}^{-1}\right)$ had a significant effect on herbage accumulation. Nuttall et al. (1991) also observed an increase in herbage accumulation of a bromegrass- 
alfalfa mixture as rates of $\mathrm{N}$ and $\mathrm{P}$ increased from 0 to $90 \mathrm{~kg} \mathrm{~N} \mathrm{ha}^{-1}$ and 0 to $20 \mathrm{~kg} \mathrm{P} \mathrm{ha}^{-1}$ respectively. The increase in dry matter production of Galega-Bromus mixture as the rates of $\mathrm{N}$ fertilizer increased from 30 to $150 \mathrm{~kg} \mathrm{ha}^{-1}$ along with $\mathrm{P}$ and $\mathrm{K}$ fertilizers $(60 \mathrm{~kg}$ $\mathrm{ha}^{-1} \mathrm{P}$ and $\left.90 \mathrm{~kg} \mathrm{ha}^{-1} \mathrm{~K}\right)$ (kshnikatkina et al. 2002).

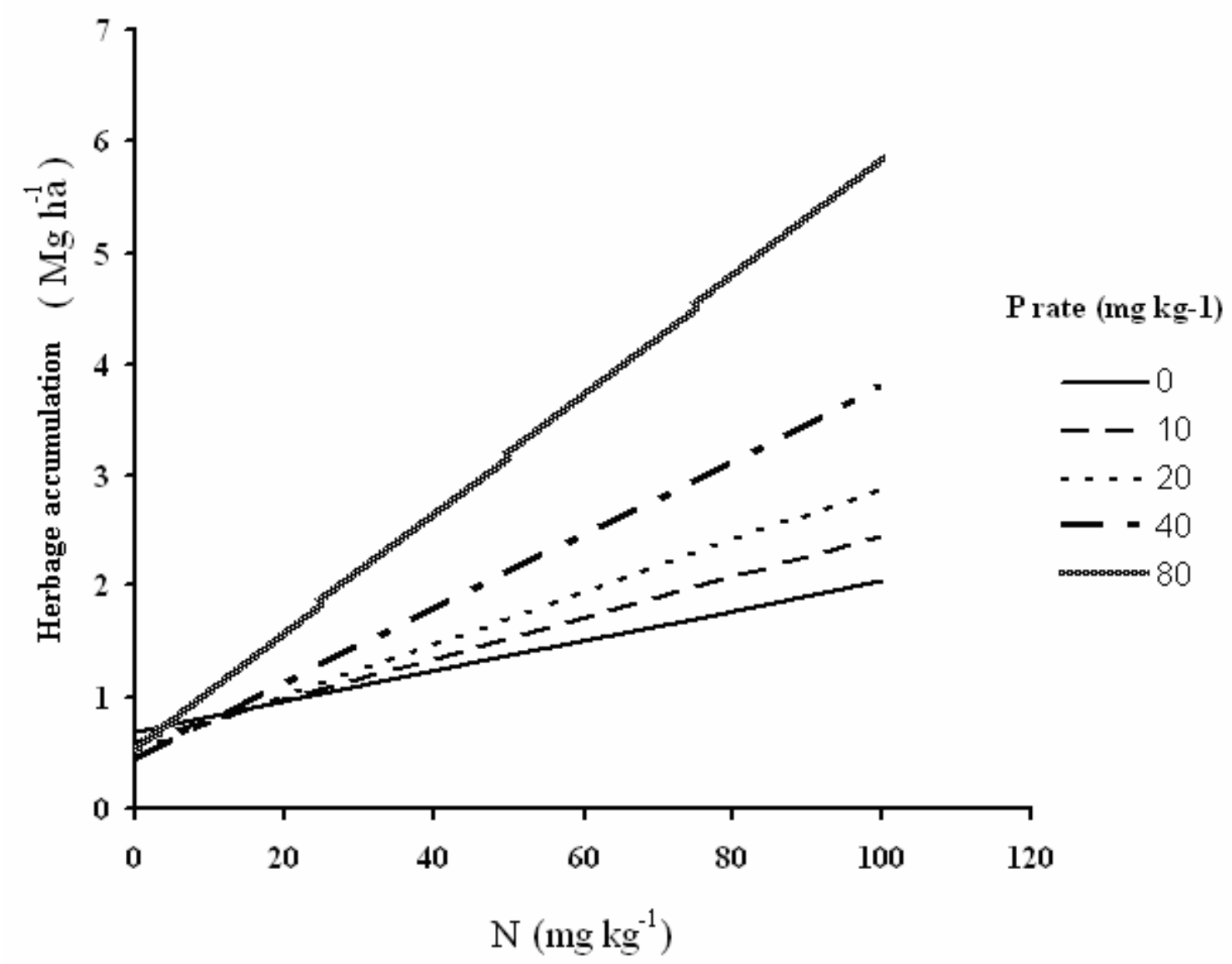

Fig. 4.4.5. Effect of $\mathrm{N}$ and $\mathrm{P}$ level on herbage accumulation of bluegrass and white clover mixture.

Herbage accumulation also responded significantly to the rate of nitrogen along with liming (Fig. 4.4.6). As the $\mathrm{pH}$ increased from 5.5 to 6.5 with the increase in $\mathrm{N}$ rate, herbage accumulation also increased. But there was a decrease in response of herbage accumulation to $\mathrm{N}$ additions at $\mathrm{pH}$ above 5.5. Timothy (Phleum pretense) exhibited a 
high response to $\mathrm{N}$ fertilization with liming on Kachemak silt loam in terms of yield as well as N-uptake by plants (Winston et al., 1976).

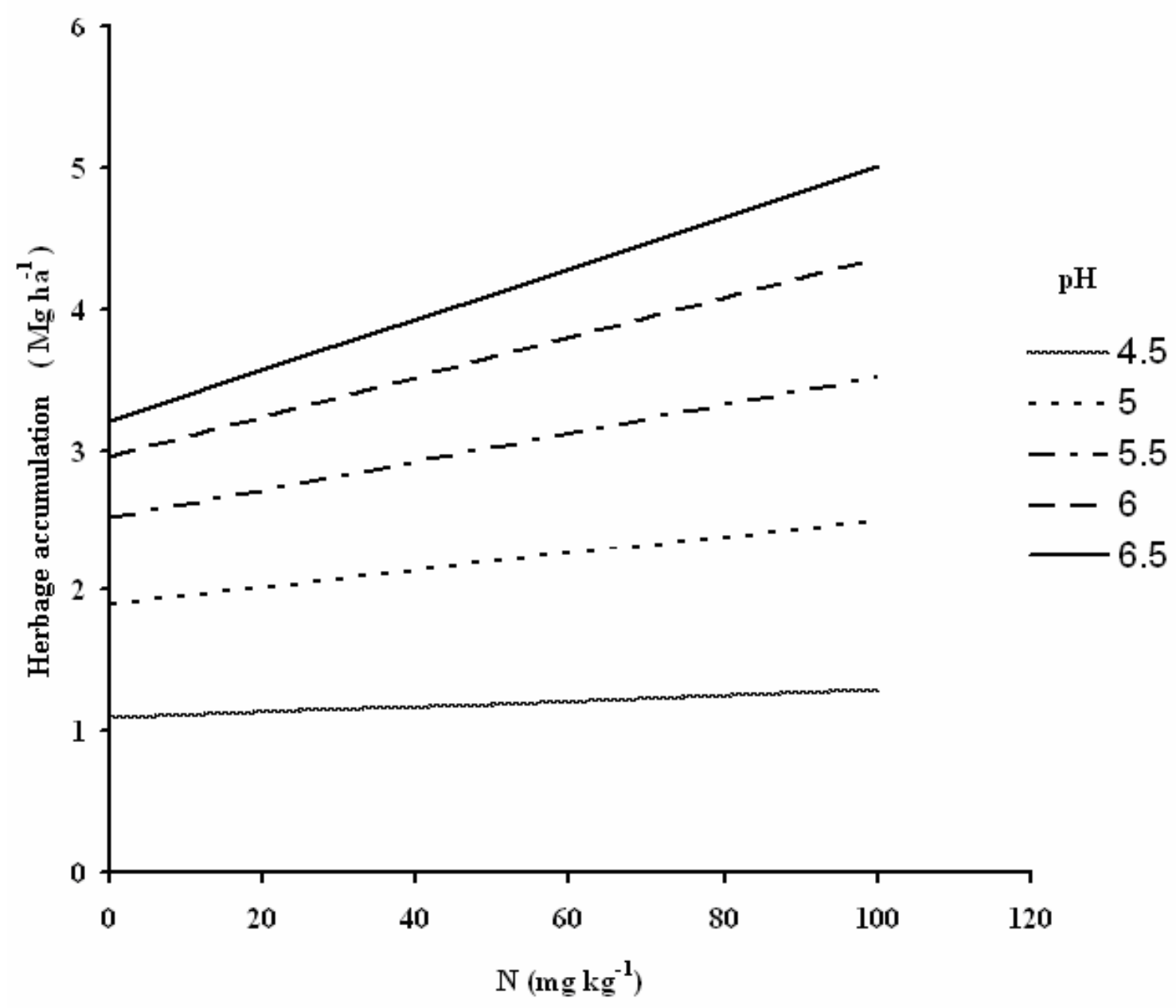

Fig. 4.4.6. Effect of nitrogen and $\mathrm{pH}$ level on herbage accumulation of bluegrass and white clover mixture.

In this study, the optimum levels of these four factors were determined to maximize herbage accumulation using ridge max option in proc step of the SAS program (Table 4.4.3). Higher herbage accumulation was observed when water potential (pF) ranged from 2.87 to $3.30, \mathrm{pH}$ from 5.50 to $6.00, \mathrm{~N}$ from 50 to $70 \mathrm{mg} \mathrm{kg}^{-1}$ and $\mathrm{P}$ from 35 
to $40 \mathrm{mg} \mathrm{kg}^{-1}$. These are the optimum conditions to be maintained to get highest herbage accumulation in bluegrass-white clover. Water potential, $\mathrm{pH}, \mathrm{N}$ and $\mathrm{P}$ showed a significant positive influence on herbage accumulation.

Table 4.4.3. Predicted response for different levels of four factors

\begin{tabular}{lccll}
\hline \multicolumn{5}{c}{ Optimum conditions } \\
\hline $\begin{array}{l}\text { Water } \\
\text { potential } \\
(\mathrm{pF})\end{array}$ & $\mathrm{pH}$ & $\mathrm{N}\left(\mathrm{mg} \mathrm{kg}^{-1}\right)$ & $\mathrm{P}\left(\mathrm{mg} \mathrm{kg}^{-1}\right)$ & $\begin{array}{l}\text { Predicted } \\
\text { herbage } \\
\text { accumulation } \\
\left(\mathrm{Mg} \mathrm{ha}^{-1}\right)\end{array}$ \\
\hline 3.30 & 5.50 & 50.0 & 40.0 & 3.30 \\
3.26 & 5.57 & 50.6 & 40.4 & 3.47 \\
3.22 & 5.63 & 51.5 & 40.6 & 3.63 \\
3.17 & 5.70 & 52.7 & 40.6 & 3.80 \\
3.13 & 5.76 & 54.3 & 40.5 & 3.97 \\
3.08 & 5.82 & 56.2 & 40.3 & 4.14 \\
3.04 & 5.87 & 58.3 & 39.4 & 4.32 \\
2.99 & 5.92 & 60.8 & 38.5 & 4.50 \\
2.95 & 5.97 & 63.5 & 37.5 & 4.70 \\
2.91 & 6.02 & 66.4 & 36.2 & 4.89 \\
2.87 & 6.07 & 69.5 & 34.8 & 5.10 \\
\hline
\end{tabular}

*Optimum conditions were obtained from ridge analysis

\subsubsection{Nutrient concentration in bluegrass - white clover herbage}

The impact of all four factors and interactions on nutrient concentration is given in Table 4.4.4 Water potential and $\mathrm{pH}$ had significant effects on uptake of all nutrients. 
Table 4.4.4. Model significance for effects of factors and their interactions on nutrient concentrations in Kentucky bluegrass-white clover mixture

\begin{tabular}{|c|c|c|c|c|c|}
\hline Source & N\% & P \% & K \% & Ca \% & Mg \% \\
\hline & \multicolumn{5}{|c|}{ 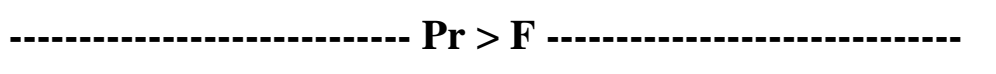 } \\
\hline $\mathrm{WP}(\mathrm{pF})$ & $<.0001$ & $<.0001$ & 0.0001 & $<.0001$ & $<.0001$ \\
\hline $\mathrm{pH}$ & $<.0001$ & $<.0001$ & $<.0001$ & $<.0001$ & $<.0001$ \\
\hline $\mathrm{N}$ & $<.0001$ & 0.9071 & 0.9021 & 0.2432 & 0.7878 \\
\hline $\mathrm{P}$ & 0.5486 & $<.0001$ & 0.6819 & 0.8861 & 0.8885 \\
\hline $\mathrm{WP}^{*} \mathrm{pH}$ & 0.9631 & 0.1092 & 0.2996 & 0.7508 & $<.0001$ \\
\hline $\mathrm{pH}^{*} \mathrm{pH}$ & 0.0138 & 0.0055 & 0.1178 & 0.0344 & 0.0812 \\
\hline $\mathrm{WP}^{*} \mathrm{~N}$ & 0.8178 & 0.9845 & 0.4382 & 0.7250 & 0.3352 \\
\hline $\mathrm{pH}^{*} \mathrm{~N}$ & 0.0337 & 0.5353 & 0.3819 & 0.3918 & 0.9376 \\
\hline$N^{*} \mathrm{~N}$ & 0.0579 & 0.9320 & 0.6692 & 0.6248 & 0.5038 \\
\hline $\mathrm{WP} * \mathrm{P}$ & 0.9476 & 0.0311 & 0.8553 & 0.4527 & 0.9769 \\
\hline $\mathrm{pH} * \mathrm{P}$ & 0.4528 & 0.0211 & 0.3002 & 0.8731 & 0.8282 \\
\hline $\mathrm{N} * \mathrm{P}$ & 0.9194 & 0.6091 & 0.6178 & 0.6639 & 0.8553 \\
\hline $\mathrm{P} * \mathrm{P}$ & 0.6610 & 0.2511 & 0.3640 & 0.7628 & 0.7671 \\
\hline
\end{tabular}

Nitrogen concentration was significantly affected by water potential, $\mathrm{pH}, \mathrm{N}$ level, and $\mathrm{pH}$ by $\mathrm{N}$ interaction (Table 4.4.4). Maximum $\mathrm{N}$ concentration was observed at higher water potential (low pF value) with $\mathrm{pH} 6.5$ and nitrogen levels between 80 and $100 \mathrm{mg}$ $\mathrm{kg}^{-1}$ (Fig. 4.4.7). But the rate of increase in $\mathrm{N}$ concentration was less above $\mathrm{pH} 5.5$ and was low between pH 6.0 and 6.5. Aggelides et al. (1999) observed that nitrate concentration in lettuce leaves was reduced when water potential decreased from $-30 \mathrm{kPa}$ to $-100 \mathrm{kPa}$. Singh and Singh (2006) found that N uptake by Dalbergia sissoo decreased as irrigation level decreased from $20 \mathrm{~mm}$ to $8 \mathrm{~mm}$. Application of $\mathrm{N}$ along with lime increased the uptake of nitrogen by meadow plants (Kasperczyk et al., 2005). Concentration of $\mathrm{N}$ in bromegrass (Bromus inermis) and alfalfa (Medicago media) was positively correlated with applied $\mathrm{N}$ rates (Nuttall, 1980). 


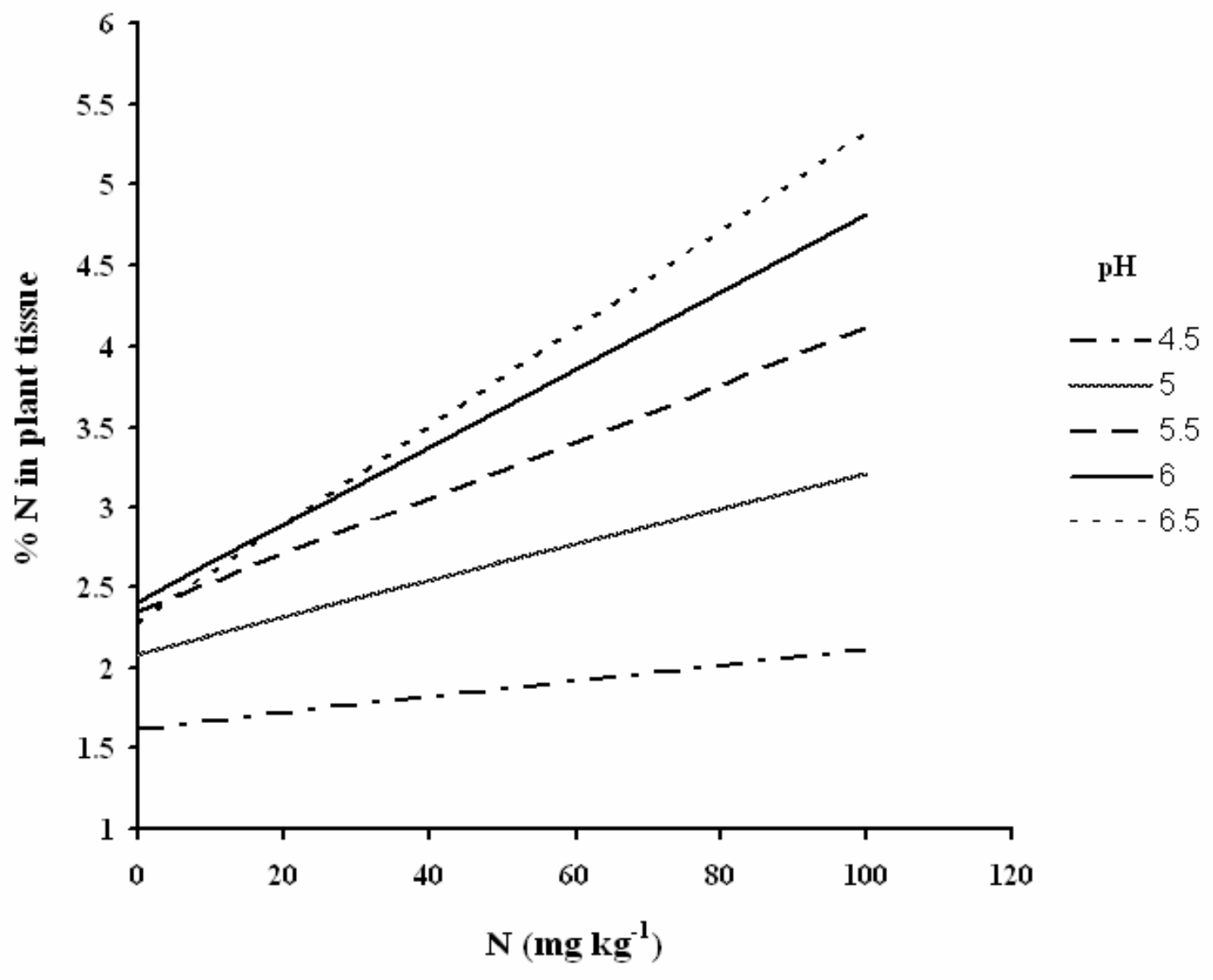

Fig. 4.4.7. Effect of $\mathrm{pH}$ and $\mathrm{N}$ level on $\mathrm{N}$ concentration of tissue 


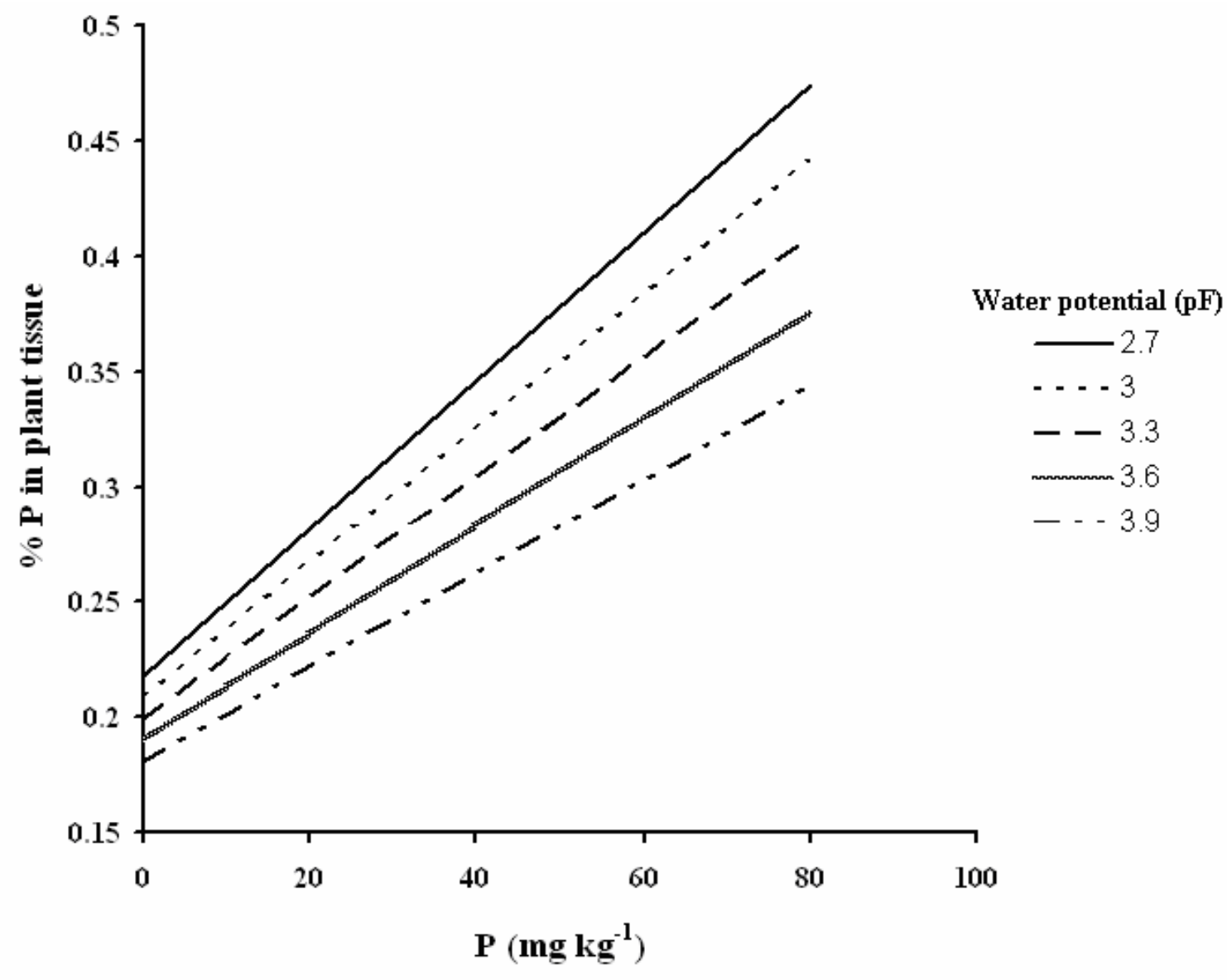

Fig. 4.4.8. Effect of water potential and $\mathrm{P}$ level on $\mathrm{P}$ concentration in tissue

Phosphorus concentration was significantly affected by water potential, $\mathrm{pH}$, and $\mathrm{P}$ level (Table 4.4.4). The interaction of $\mathrm{P}$ level with water potential and $\mathrm{pH}$ also had significant influence on $\mathrm{P}$ concentration. The increased $\mathrm{P}$ concentration in plant tissue at the higher water potential may be due to enhancement in the diffusion process, which was observed previously by several researchers (Mederski and Wilson, 1960) (Fig. 4.4.8). Increase in $\mathrm{pH}$ up to 6.0 due to liming also had a significant effect on $\mathrm{P}$ concentration (Fig. 4.4.9). But $\mathrm{P}$ concentration was not affected by the increase of $\mathrm{pH}$ above 6.0. 
Mayfield et al. (2002) also observed maximum uptake of P by Nandina domestica grown in soil-less media in treatments that received lime compared to the un-limed controls. Concentration of $\mathrm{P}$ in pasture herbage was significantly increased by application of $\mathrm{P}$ fertilizer $\left(20 \mathrm{~kg} \mathrm{ha}^{-1}\right)$, from 0.16 to $0.30 \%$ in alfalfa (Medicago media) and 0.16 to $0.31 \%$ in bromegrass (Bromus inermis) (Nuttall, 1980).

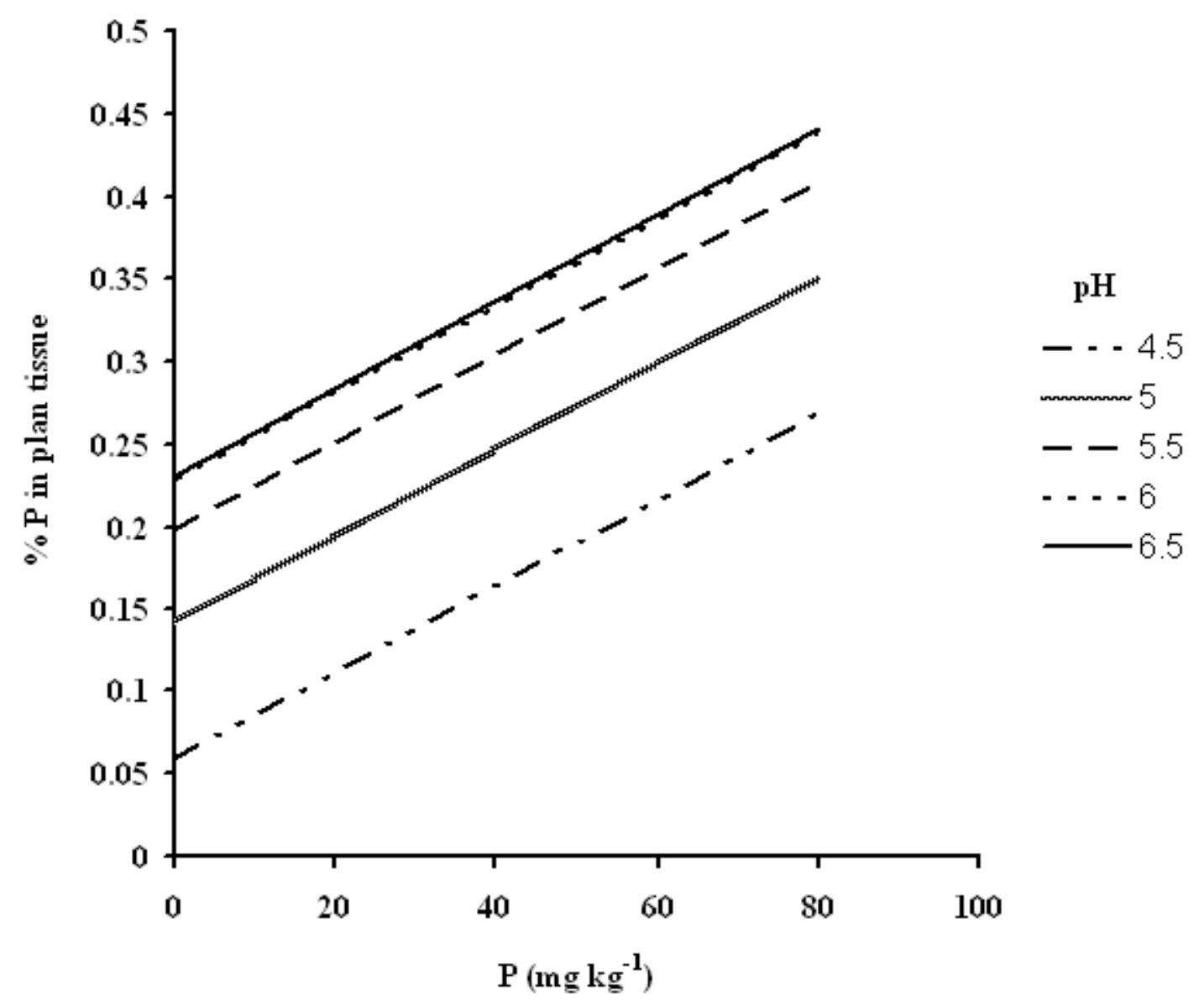

Fig. 4.4.9. Effect of $\mathrm{pH}$ and $\mathrm{P}$ level on $\mathrm{P}$ concentration in tissue 
Concentration of $\mathrm{K}, \mathrm{Ca}$, and $\mathrm{Mg}$ in shoots was significantly affected by water potential and $\mathrm{pH}$ of soil (Table. 4.4.4). A significant effect of water potential and $\mathrm{pH}$ was observed in the case of Mg uptake (Fig. 4.4.10). The increased concentrations of $\mathrm{K}, \mathrm{Ca}$, and $\mathrm{Mg}$ were observed at higher water potentials which may be due to an increase in the magnitude of processes such as mass flow and diffusion (Mackay and Barber, 1985). The increase in $\mathrm{pH}$ also enhanced the concentration of cations $(\mathrm{K}, \mathrm{Ca}$, and $\mathrm{Mg})$ in this study. Kasperczyk et al. (2005) also observed an increase in concentration of calcium and magnesium in meadow plants due to application of lime. The concentration of potassium was not affected by $\mathrm{K}$ applied with $\mathrm{P}\left(\mathrm{KH}_{2} \mathrm{PO}_{4}\right)$ in this study, but was affected by levels of water potential and $\mathrm{pH}$.

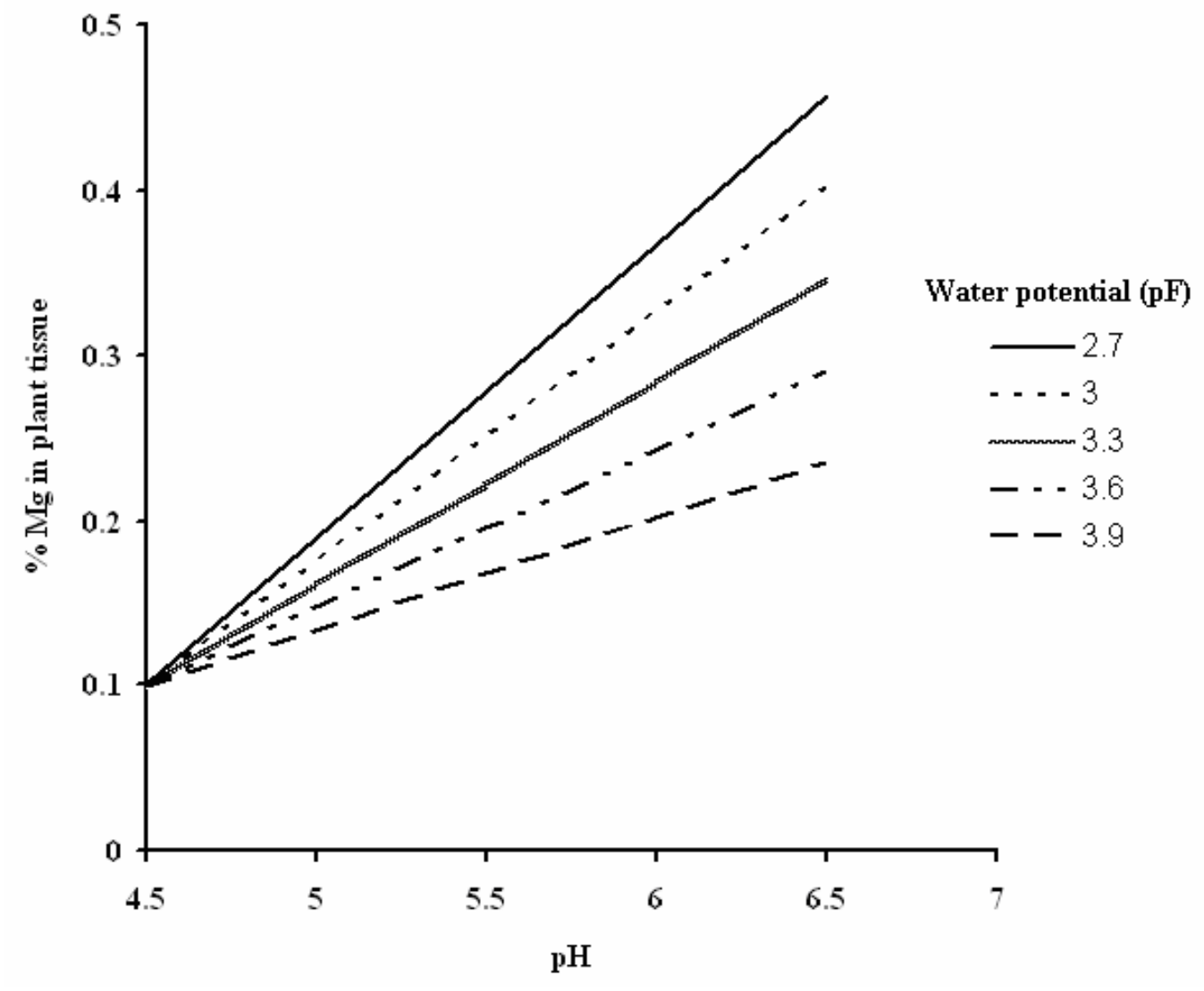

Fig. 4.4.10. Effect of water potential and $\mathrm{pH}$ on $\mathrm{Mg}$ concentration in tissue 
This study showed that soil water potential, $\mathrm{pH}$, and $\mathrm{N}$ and $\mathrm{P}$ levels need emphasis when designing management practices for low-input production systems using acidic pasture lands in West Virginia. The response yield function determined in this study might be practically useful for grassland farmers in Appalachian region. There is still a need to explore these four factors to reduce common environmental problems of managed pasture lands, such as leaching of applied nitrogen and phosphorus fertilizers which may contaminate ground water and adjacent bodies of surface water.

\subsection{REFERENCES}

Aggelides, S., I. Assimakopoulos, P. Kerkides, and A. Skondras. 1999. Effects of soil water potential on the nitrate content and the yield of lettuce. Commun. Soil Sci. Plant Anal. 30:235-243.

Alabi, H.E., R.C. Sorensen, D. Knudsen, and G.W. Rehm. 1986. Comparison of several lime requirement methods on coarse textured soils of northeastern Nebraska. Soil Sci. Soc. Am. J. 50:937-947.

Arnold, P.W., F. Hunter, and P. G. Fernandez. 1976. Long-term grassland experiments at Cockle Park. Ann. Agron. 27:1027-1042.

Chapman, H.D. 1965. Cation exchange capacity. p.891-900. In C.A. Black (ed.) Methods of Soil Analysis, Part 2: Chemical and Microbiological Properties. Am. Soc. Agron., Madison, WI, USA.

Cockayne, A.H. 1956. Grasslands of New Zealand. p.585-595. In Proceedings of the VII International Grassland Congress, Palmerston North, New Zealand. 
Elliott, F.J., and B. Thomas. 1934. The yields and composition of meadow hay from certain of the Palace Leas plots at Cockle Park. J. Agr. Sci. (Cambridge) 24:379389.

Fiez, T.E., B.C. Miller, and W.L. Pan. 1994. Winter wheat yield and grain protein across varied landscape positions. Agron. J. 86:1026-1032.

Gardner, H.W., and H.V. Garner. 1953. The use of lime in british agriculture. Farmer and Stock Breeder Publications, London, England.

Gutierrez-Boem, F.H., and G.W. Thomas. 1998. Phosphorus nutrition affects wheat response to water deficits. Agron. J. 90:166-171.

Israel, D.W. 1987. Investigation of the role of phosphorus in symbiotic dinitrogen fixation. Plant Physiol. 84:835-840.

Jones, L.I. 1967. Studies on hill land in Wales, Technical bulletin No. 2. Welsh Plant Breeding Station, Aberystwyth, England.

Kasperczyk, M., W. Szewczyk, and P. Kacorzyk. 2005. Effects of liming, mineral fertilizing and oversowing on macroelement uptakes by meadow plants. Towarzystwo Chemii i Inzynierii Ekologicznej 12:821-825 (abstract only).

Koerselman, W., M.B. Van Kerkhoven, and J.T.A. Verhoeven. 1993. Release of inorganic $\mathrm{N}, \mathrm{P}$ and $\mathrm{K}$ in peat soils; effect of temperature, water level. Biogeochem. 20:63-81.

Kshnikatkina, A.N., V.A. Varlmov, V.A. Gushchina, and G.S.A. Penzenskaya. 2002. Mineral fertilizers and herbage productivity. Zemledelie 5:23-24 (abstract only). 
Ledgard, S.F. 2001. Nitrogen cycling in low input legume-based agriculture, with emphasis on legumes/grass pastures. Plant and Soil 228:43-59.

Mackay, A.D., and S. A. Barber. 1985. Soil moisture effects on root growth and phosphorus uptake by corn. Agron. J. 77:519-523.

Malhi, S.S., R.P. Zentner, and K. Heier. 2002. Effectiveness of alfalfa in reducing fertilizer $\mathrm{N}$ input for optimum forage yield, protein concentration, returns and energy performance of bromegrass-alfalfa mixtures. Nutr. Cycling Agroecosyst. 62:219-227.

Mayfield, J.L., J.L. Sibley, E.H. Simonne, and D.J. Eakes. 2002. Effect of liming materials on media $\mathrm{pH}$ and overall growth and nutrition of dwarf nandina. $\mathrm{J}$. Plant Nutr. 25:1377-87.

Mederski, H.J., and J.H. Wilson. 1960. Relation of soil moisture to ion absorption by corn plants. Soil Sci. Soc. Am. Proc. 24:149-152.

Menzies, N.W., L.C. Bell, and D.G. Edwards. 1994. Exchange and solution phase chemistry of acid, highly weathered soils.1. Characterstics of soils and effect of lime and gypsum amendments. Aust. J. Soil Res. 32:251-267.

Milton, W.E.J., and R.O. Davies. 1947. The yield, botanical and chemical composition of natural hill herbage under manuring, controlled grazing and hay conditions. J. Ecol. 35:65-95.

Myers, R.H., and D.C. Montgomery. 1995. Response Surface Methodology: Process and Production in Optimization Using Designed Experiments. John Wiley \& Sons, Inc, NY, USA. 
Nuttall, W.F. 1980. Effect of nitrogen and phosphorus fertilizers on a bromegrass and alfalfa mixture grown under two systems of pasture management. II. Nitrogen and phosphorus uptake and concentration in herbage. Agron. J. 72:295-8.

Nuttall, W.F., D.H. McCartney, S. Bittman, P.R. Horton, and J. Waddington. 1991. The effect of nitrogen, phosphorus and sulfur fertilizer, temperature and precipitation on the yield of bromegrass and alfalfa pasture established on luvisolic soil. Can. J. of Plant Sci. 71:1047-55.

Oliver, H., A., F. Lotter, and G. Lemcke. 2001. Loss on ignition as a method for estimating organic and carbonate content in sediments: reproducibility and comparability of results. J. Paleolimnol. 25:101-110.

Ozgur, T., and A. Sebahattin. 2006. Effects of different levels of phosphorus on forage yield and quality of white clover (Trifolium repens L.). Asian J. of Plant Sci. 5:201-206.

Paula, M.B., F.D. Nogueira, H. Andrade, and J.E. Pittis. 1987. Effect of liming on dry matter yield of wheat in pots of low humic gley soil. Plant and Soil 97:85-91.

Pier, J.W., and T.A. Doerge. 1995. Nitrogen and water interactions in trickle-irrigated watermelon. Soil Sci. Soc. Am. J. 59:145-150.

Rechcigal, R.W., and G.G. Payne. 1990. Comparison of microwave digestion system to other digestion methods for plant tissue analysis. Commun. Soil Sci. Plant Anal. 21:2209-2218.

Reith, J.W.S., R.H.E. Inkson, A.B. Stewart, W. Holmes, D.S. Maclusky, D. Reid, R.G. Heddle, D. Clouston., and G.J.F. Copeman. 1961. The effects of fertilizers on 
herbage production. 1. The effects of nitrogen, phosphate and potash on yield. J. Agr. Sci. (Cambridge) 56: 17-29.

Rhodes, I., and F. Ortega. 1997. Forage legumes. p. 15-27. In Seeds of Progress. British Grassland Society Occasional Symposium No. 31 (Ed. J.R. Weddell), British Grassland Society, Reading, England.

Rochon, J.J., C.J. Doyle, J.M. Greef, A. Hopkins, G. Molle, M. Sitzia, D. Scolefield, and C.J. Smith. 2004. Grazing legumes in Europe: A review of their status, management, benefits, research needs and future prospects. Grass Forage Sci. 59:197-214.

Saeed, I.A.M., and A.H. El-Nadi. 1998. Forage sorghum yield and water use efficiency under variable irrigation. Irrig. Sci. 18:67-71

Shempel, V., and N.P. Kukresh. 1975. Effect of liming and mineral fertilizers on the chemical composition of red clover plants. Seryya Sel'skagaspadarchykh Navuk 4:41-6. (abstract only)

Singh, B., and G. Singh. 2006. Effects of controlled irrigation on water potential, nitrogen uptake and biomass production in Dalbergia sissoo seedlings. Environ. Exper. Bot. 55: 209-219.

Sternberg, R.W., and J.S. Creager. 1961. Comparative efficiencies of size analysis by hydrometer and pipette methods. J. Sediment Petrol. 31:96-100.

Winston, M.L., P.F. Martin, and G.R. Smith. 1976. Lime and nitrogen influence on timothy yield and composition. Agron. J. 68:881-885. 


\section{APPENDIX}

Table A1. Mean lime requirement $\left(\mathrm{Mg} \mathrm{ha}^{-1}\right)$ values by direct calcium hydroxide titration method

\begin{tabular}{|c|c|c|c|c|c|}
\hline \multirow[b]{3}{*}{ Soil } & \multirow[b]{3}{*}{ Order } & \multicolumn{4}{|c|}{$\begin{array}{l}\text { Lime requirement }\left(\mathrm{Mg} \mathrm{ha}^{-1}\right) \text { by } \\
\text { direct calcium hydroxide titration }\end{array}$} \\
\hline & & \multicolumn{4}{|c|}{$\begin{array}{c}\text { Target pH } \\
\end{array}$} \\
\hline & & 5.5 & 6.0 & 6.2 & 6.5 \\
\hline 2 & Alfisol & 0.50 & 1.22 & 1.56 & 2.13 \\
\hline 8 & Alfisol & 1.25 & 2.22 & 2.63 & 3.27 \\
\hline 9 & Alfisol & 1.80 & 2.88 & 3.32 & 4.04 \\
\hline 11 & Alfisol & 2.98 & 4.61 & 5.27 & 6.26 \\
\hline 12 & Alfisol & 1.56 & 2.82 & 3.33 & 4.08 \\
\hline 14 & Alfisol & 1.29 & 3.01 & 3.72 & 4.89 \\
\hline 16 & Alfisol & 2.18 & 3.41 & 3.85 & 4.40 \\
\hline 17 & Alfisol & 0.73 & 1.30 & 1.54 & 1.90 \\
\hline 19 & Alfisol & 2.00 & 4.48 & 5.57 & 7.36 \\
\hline 22 & Alfisol & 1.20 & 2.28 & 2.74 & 3.47 \\
\hline 24 & Alfisol & 2.01 & 4.20 & 5.12 & 6.55 \\
\hline 25 & Alfisol & 1.10 & 2.39 & 2.94 & 3.84 \\
\hline 26 & Alfisol & 1.34 & 2.77 & 3.39 & 4.44 \\
\hline 1 & Inceptisol & 1.07 & 1.91 & 2.21 & 2.69 \\
\hline 3 & Inceptisol & 0.96 & 1.92 & 2.30 & 2.88 \\
\hline 4 & Inceptisol & 0.78 & 1.69 & 2.05 & 2.57 \\
\hline 6 & Inceptisol & 1.07 & 2.86 & 3.62 & 4.80 \\
\hline 7 & Inceptisol & 0.69 & 1.53 & 1.89 & 2.52 \\
\hline 10 & Inceptisol & 1.48 & 2.58 & 3.03 & 3.72 \\
\hline 18 & Inceptisol & 0.76 & 1.67 & 2.03 & 2.62 \\
\hline 13 & Ultisol & 0.89 & 1.99 & 2.47 & 3.28 \\
\hline 15 & Ultisol & 1.70 & 2.81 & 3.21 & 3.78 \\
\hline 20 & Ultisol & 0.84 & 1.67 & 1.98 & 2.44 \\
\hline 21 & Ultisol & 2.31 & 3.41 & 3.90 & 4.69 \\
\hline 23 & Ultisol & 1.99 & 2.81 & 3.16 & 3.75 \\
\hline
\end{tabular}


Table A2. Mean lime requirement $\left(\mathrm{Mg} \mathrm{ha}^{-1}\right)$ values by Shoemaker McLean Pratt buffer (SMP) method

\begin{tabular}{|c|c|c|c|c|}
\hline \multirow[b]{3}{*}{ soil } & \multicolumn{4}{|c|}{ Lime requirement (Mg ha ${ }^{-1}$ ) by SMP buffer method } \\
\hline & \multicolumn{4}{|c|}{ Target $\mathrm{pH}$} \\
\hline & order & 5.5 & 6.0 & \\
\hline 2 & Alfisol & 4.87 & 6.58 & 8.29 \\
\hline 8 & Alfisol & 5.72 & 7.44 & 9.15 \\
\hline 9 & Alfisol & 4.01 & 5.73 & 7.44 \\
\hline 11 & Alfisol & 13.17 & 14.88 & 16.59 \\
\hline 12 & Alfisol & 6.58 & 8.29 & 10 \\
\hline 14 & Alfisol & 4.87 & 6.58 & 8.29 \\
\hline 16 & Alfisol & 3.16 & 4.87 & 6.58 \\
\hline 17 & Alfisol & 2.3 & 4.02 & 5.73 \\
\hline 19 & Alfisol & 10.86 & 12.57 & 14.28 \\
\hline 22 & Alfisol & 2.3 & 4.02 & 5.73 \\
\hline 24 & Alfisol & 11.71 & 13.42 & 15.14 \\
\hline 25 & Alfisol & 4.27 & 5.98 & 7.69 \\
\hline 26 & Alfisol & 5.72 & 7.44 & 9.15 \\
\hline 1 & Inceptisol & 4.01 & 5.73 & 7.44 \\
\hline 3 & Inceptisol & 4.01 & 5.73 & 7.44 \\
\hline 4 & Inceptisol & 4.01 & 5.73 & 7.44 \\
\hline 6 & Inceptisol & 4.87 & 6.58 & 8.29 \\
\hline 7 & Inceptisol & 4.87 & 6.58 & 8.29 \\
\hline 10 & Inceptisol & 7.44 & 9.15 & 10.86 \\
\hline 18 & Inceptisol & 4.01 & 5.73 & 7.44 \\
\hline 13 & Ultisol & 3.16 & 4.87 & 6.58 \\
\hline 15 & Ultisol & 6.41 & 9.12 & 9.83 \\
\hline 20 & Ultisol & 4.01 & 5.73 & 7.44 \\
\hline 21 & Ultisol & 10.43 & 12.14 & 13.85 \\
\hline 23 & Ultisol & 4.01 & 5.73 & 7.44 \\
\hline
\end{tabular}


Table A3. Mean lime requirement $\left(\mathrm{Mg} \mathrm{ha}^{-1}\right)$ values by Adam Evans buffer (AEB) method

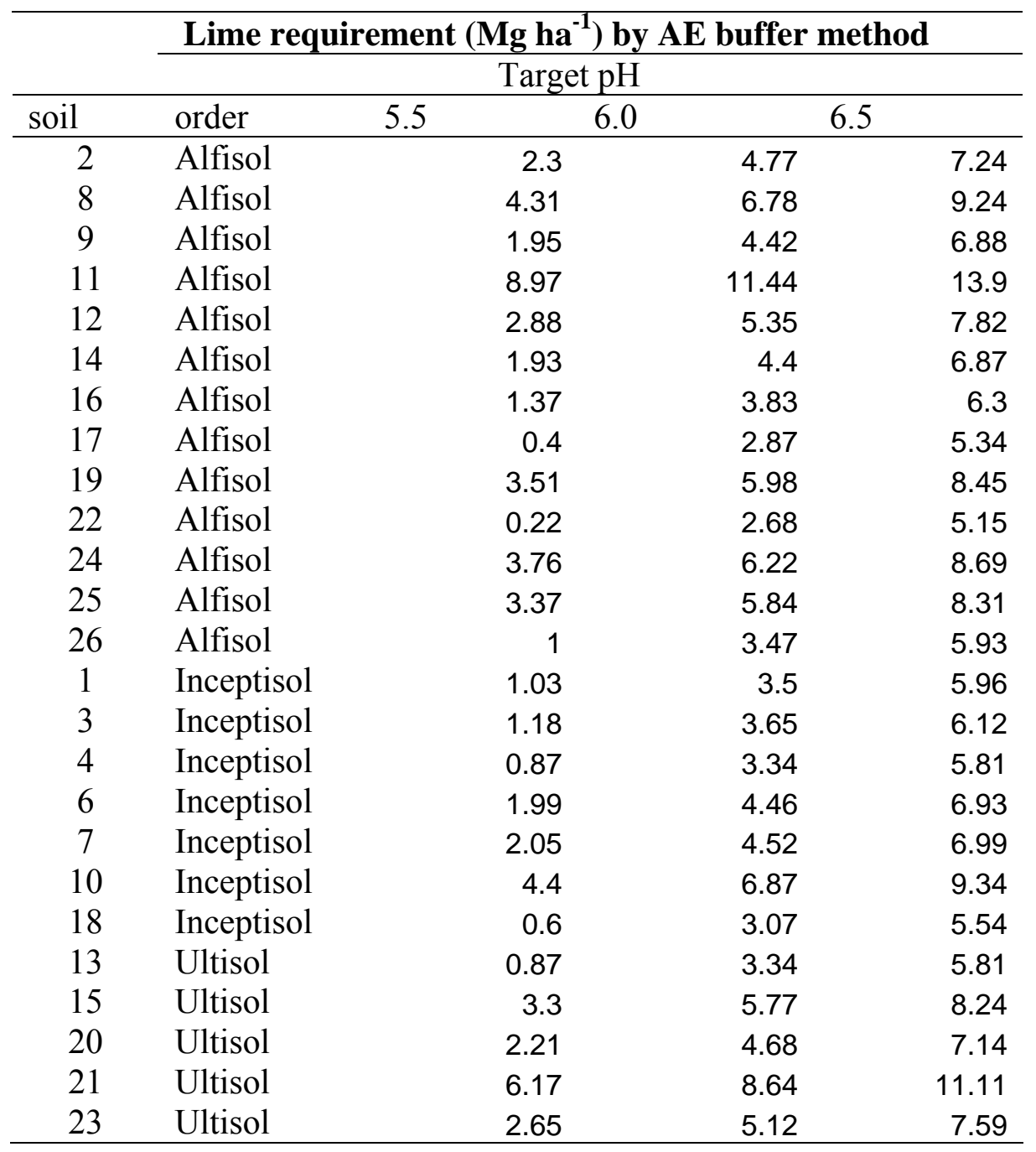


Table A4. Mean lime requirement $\left(\mathrm{Mg} \mathrm{ha}^{-1}\right)$ values by Mehlich single buffer (MB) method

\begin{tabular}{clrrr}
\hline \multicolumn{5}{c}{ Lime requirement (Mg ha $\mathbf{~}^{-1}$ ) by Mehlich buffer method } \\
\cline { 2 - 5 } soil & order & 5.5 & 6.0 & \multicolumn{3}{c}{ Target $\mathrm{pH}$} \\
\hline 2 & Alfisol & 2.53 & 4.68 & 4.85 \\
8 & Alfisol & 3.16 & 5.66 & 5.97 \\
9 & Alfisol & 2.53 & 4.68 & 4.85 \\
11 & Alfisol & 7.61 & 12.21 & 13.37 \\
12 & Alfisol & 3.16 & 5.66 & 5.97 \\
14 & Alfisol & 2.53 & 4.68 & 4.85 \\
16 & Alfisol & 1.94 & 3.73 & 3.77 \\
17 & Alfisol & 4.51 & 2.82 & 2.71 \\
19 & Alfisol & 2.53 & 7.71 & 8.31 \\
22 & Alfisol & 1.37 & 4.68 & 4.85 \\
24 & Alfisol & 4.51 & 7.71 & 8.31 \\
25 & Alfisol & 3.16 & 5.66 & 5.97 \\
26 & Alfisol & 2.53 & 4.68 & 4.85 \\
1 & Inceptisol & 2.53 & 4.68 & 4.85 \\
3 & Inceptisol & 3.16 & 5.66 & 5.97 \\
4 & Inceptisol & 2.53 & 4.68 & 4.85 \\
6 & Inceptisol & 3.82 & 6.67 & 7.12 \\
7 & Inceptisol & 2.53 & 4.68 & 4.85 \\
10 & Inceptisol & 4.51 & 7.71 & 8.31 \\
18 & Inceptisol & 2.53 & 4.68 & 4.85 \\
13 & Ultisol & 2.53 & 4.68 & 4.85 \\
15 & Ultisol & 3.16 & 5.66 & 5.97 \\
20 & Ultisol & 1.94 & 3.73 & 3.77 \\
21 & Ultisol & 6.79 & 11.04 & 12.05 \\
23 & Ultisol & 3.16 & 5.66 & 5.97 \\
\hline
\end{tabular}


Table.A5. Experimental design used for bluegrass (alone) and bluegrass and white clover mixed cropping system

\begin{tabular}{|c|c|c|c|c|}
\hline $\begin{array}{l}\text { Treatment } \\
\text { No. }\end{array}$ & $\begin{array}{l}\text { Water } \\
\text { potential }(\mathrm{pF})\end{array}$ & pH & $\mathrm{N}\left(\mathrm{mg} \mathrm{kg}^{-1}\right)$ & $P\left(\mathrm{mg} \mathrm{kg}^{-1}\right)$ \\
\hline 1 & 3.91 & 5 & 10 & 10 \\
\hline 2 & 3.91 & 6 & 10 & 10 \\
\hline 3 & 3.91 & 5.5 & 100 & 20 \\
\hline 4 & 3.91 & 4.5 & 25 & 20 \\
\hline 5 & 3.91 & 5.5 & 25 & 80 \\
\hline 6 & 3.91 & 5 & 50 & 10 \\
\hline 7 & 3.91 & 6 & 10 & 40 \\
\hline 8 & 3.91 & 5.5 & 25 & 20 \\
\hline 9 & 3.91 & 5 & 10 & 40 \\
\hline 10 & 3.91 & 6.5 & 25 & 20 \\
\hline 11 & 3.91 & 5.5 & 25 & 20 \\
\hline 12 & 3.91 & 5 & 50 & 40 \\
\hline 13 & 3.91 & 5.5 & 25 & 0 \\
\hline 14 & 3.91 & 6 & 50 & 10 \\
\hline 15 & 3.91 & 5.5 & 0 & 20 \\
\hline 16 & 3.91 & 6 & 50 & 40 \\
\hline 17 & 2.7 & 5 & 10 & 10 \\
\hline 18 & 2.7 & 6 & 10 & 10 \\
\hline 19 & 2.7 & 5.5 & 100 & 20 \\
\hline 20 & 2.7 & 4.5 & 25 & 20 \\
\hline 21 & 2.7 & 5.5 & 25 & 80 \\
\hline 22 & 2.7 & 5 & 50 & 10 \\
\hline 23 & 2.7 & 6 & 10 & 40 \\
\hline 24 & 2.7 & 5.5 & 25 & 20 \\
\hline 25 & 2.7 & 5 & 10 & 40 \\
\hline 26 & 2.7 & 6.5 & 25 & 20 \\
\hline 27 & 2.7 & 5.5 & 25 & 20 \\
\hline 28 & 2.7 & 5 & 50 & 40 \\
\hline 29 & 2.7 & 5.5 & 25 & 0 \\
\hline 30 & 2.7 & 6 & 50 & 10 \\
\hline 31 & 2.7 & 5.5 & 0 & 20 \\
\hline 32 & 2.7 & 6 & 50 & 40 \\
\hline
\end{tabular}




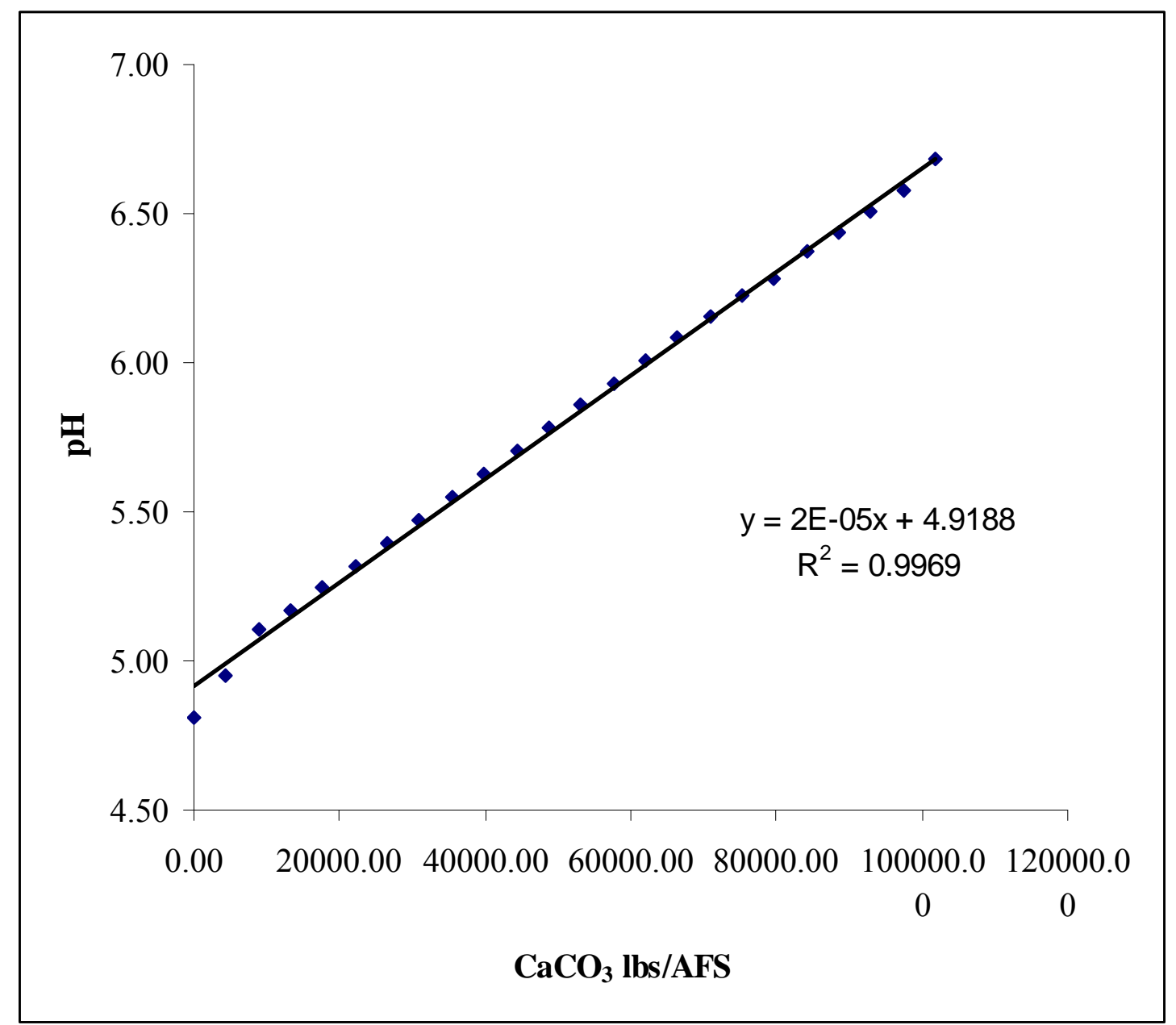

Fig A1. Lime response curve of green house soil 


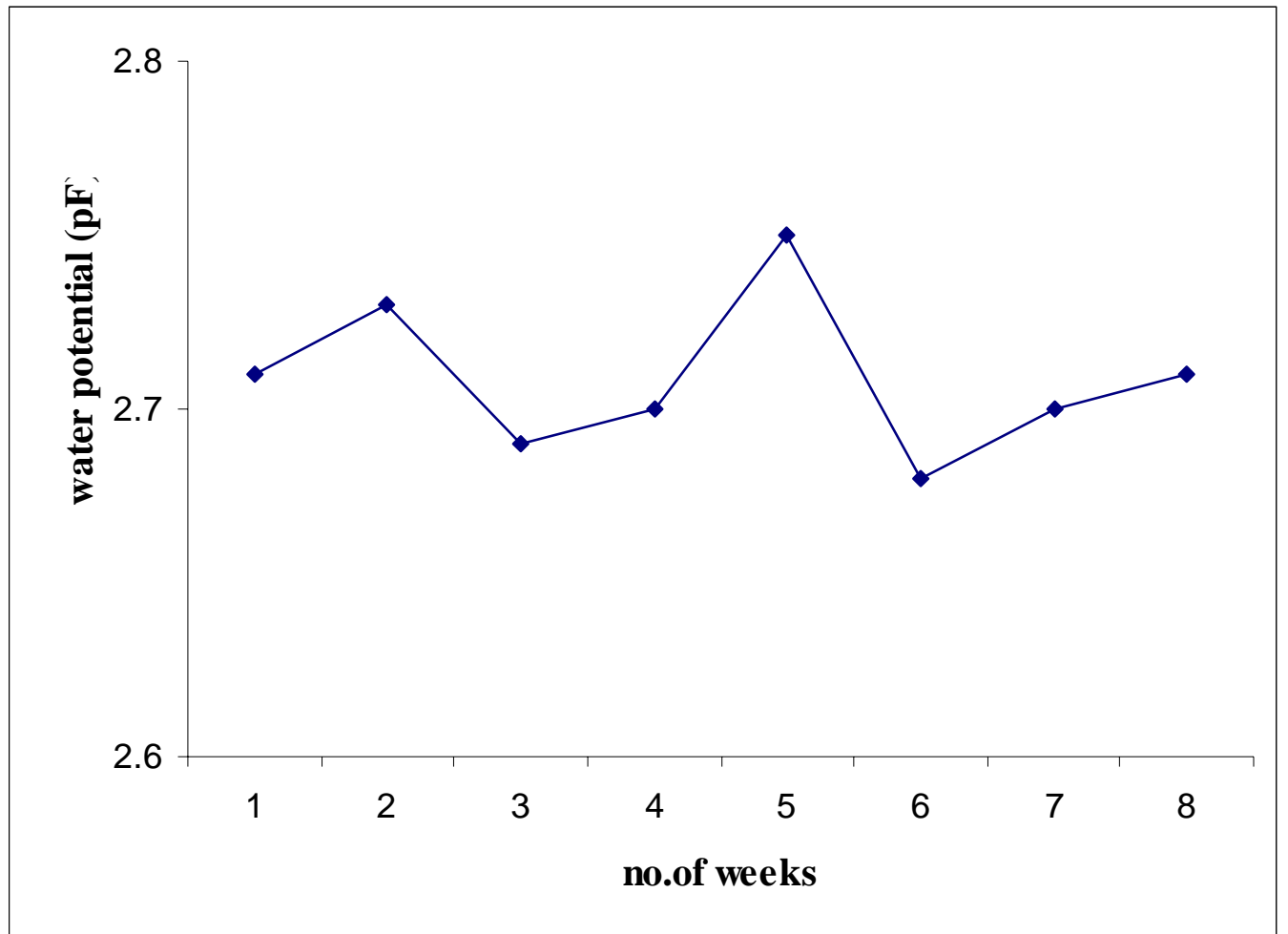

Fig A2. Moisture pattern in high water potential treatment plants 


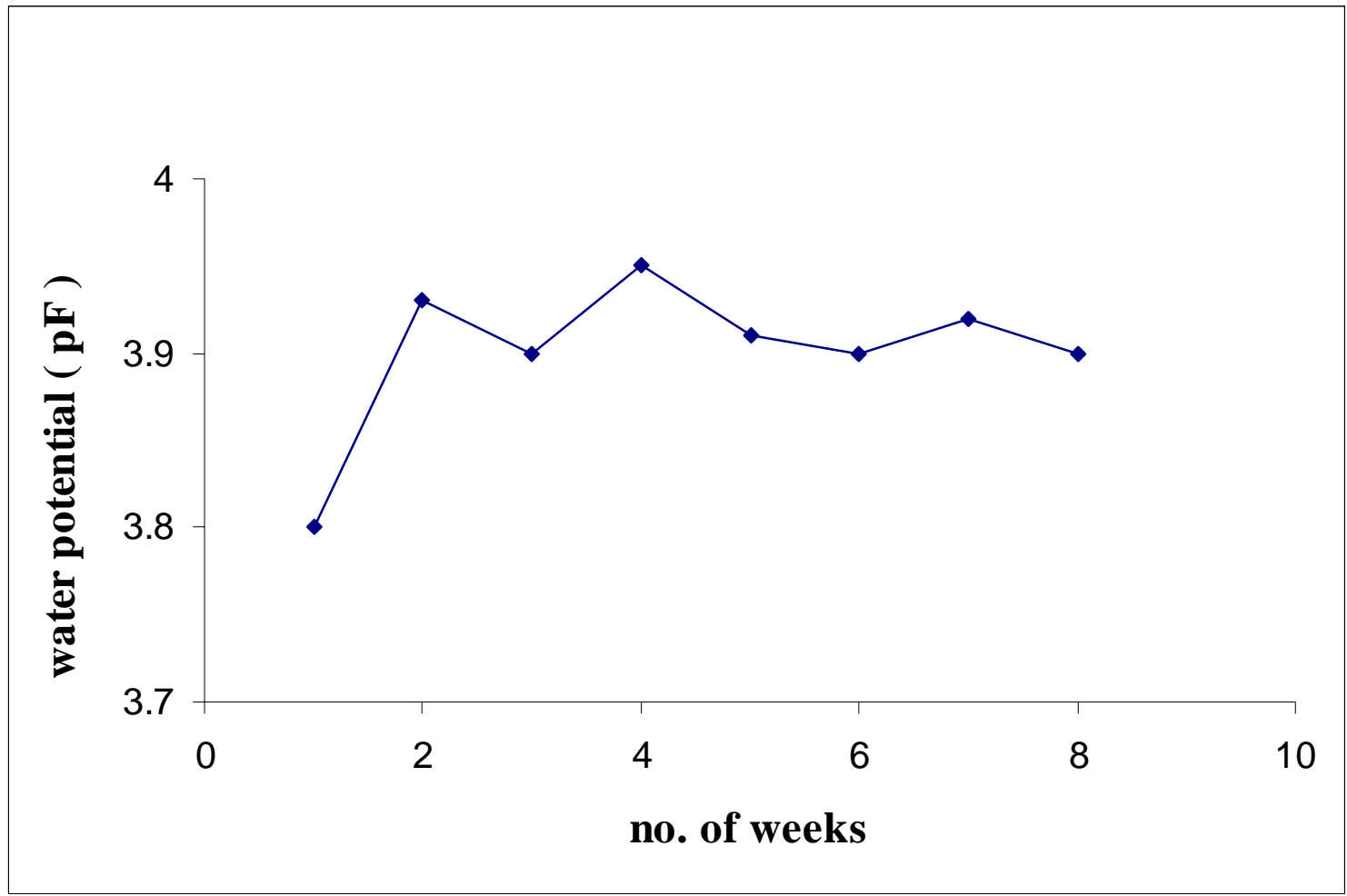

Fig A3. Moisture pattern in low water potential treatment plants 